\title{
Hybrid Concentrated Solar Thermal Power Systems: A Review
}

\author{
Kody M. Powell \\ University of Utah \\ Khalid Rashid \\ University of Utah \\ Kevin Ellingwood \\ University of Utah \\ Jake Tuttle \\ University of Utah \\ Brian D. Iverson \\ Brigham Young University - Provo, bdiverson@byu.edu
}

Follow this and additional works at: https://scholarsarchive.byu.edu/facpub

Part of the Chemical Engineering Commons, and the Mechanical Engineering Commons

\section{Original Publication Citation}

Powell, K. M., Rashid, K., Ellingwood, K., Tuttle, J., \& Iverson, B. D. (2017). Hybrid concentrated solar thermal power systems: A review. Renewable and Sustainable Energy Reviews, 80, 215-237.

\section{BYU ScholarsArchive Citation}

Powell, Kody M.; Rashid, Khalid; Ellingwood, Kevin; Tuttle, Jake; and Iverson, Brian D., "Hybrid Concentrated Solar Thermal Power Systems: A Review" (2017). Faculty Publications. 1872.

https://scholarsarchive.byu.edu/facpub/1872

This Peer-Reviewed Article is brought to you for free and open access by BYU ScholarsArchive. It has been accepted for inclusion in Faculty Publications by an authorized administrator of BYU ScholarsArchive. For more information, please contact ellen_amatangelo@byu.edu. 


\title{
Hybrid Concentrated Solar Thermal Power Systems: A Review
}

Submitted to Renewable and Sustainable Energy Reviews

January $2^{\text {nd }}, 2017$

\author{
Kody M. Powell, Ph.D. (Corresponding Author) \\ University of Utah \\ Department of Chemical Engineering 50 \\ S Central Campus Drive \\ Salt Lake City, Utah 84112 kody.powell@utah.edu
}

Khalid Rashid

University of Utah

Department of Chemical Engineering

Kevin Ellingwood

University of Utah

Department of Chemical Engineering

Jake Tuttle

University of Utah

Department of Chemical Engineering

Brian D. Iverson, Ph.D.

Brigham Young University

Department of Mechanical Engineering 
Abstract - Concentrated solar power (CSP), or solar thermal power, is an ideal technology to hybridize with other energy technologies for power generation. CSP shares technology with conventional power generation and can be readily integrated with other energy types into a synergistic system, which has many potential benefits including increased dispatchability and reliability, improved efficiency, reduced capital costs through equipment sharing, and the opportunity for flexible operation by alternating between energy sources, which can lead to improved overall efficiency through synergy of the different energy sources. Another advantage of CSP technology is the ability to readily store via thermal energy storage (TES), making the intermittent solar resource dispatchable. A review of CSP hybridization strategies with coal, natural gas, biofuels, geothermal, photovoltaic (PV), and wind is given. An overview of different configurations for hybridizing CSP with these other energy sources is also provided. Hybridized CSP plants present different types and levels of synergy, depending on the hybrid energy source, the location of the plant, the CSP technology used, and the plant configuration. Coal, natural gas, and biofuel hybrids with CSP present many opportunities to inject solar heat at various temperatures. These combustible fuels provide reliability, dispatchability, and flexibility but are not entirely renewable solutions (with the exception of biofuels). Geothermal, wind, and PV hybrid designs with CSP can be entirely renewable, but lack some of the benefits of hydrocarbon fuels. Effective geothermal-CSP hybrid designs require low temperature operation where efficiency is limited by the power cycle. Wind-CSP and PVT (photovoltaic/thermal) lack dispatchability, but have other advantages. The pursuit of ideal CSP hybrid systems is an important research topic as it allows for further development of CSP technologies while providing an immediate solution that increases the use of solar power. 


\section{Table of Contents}

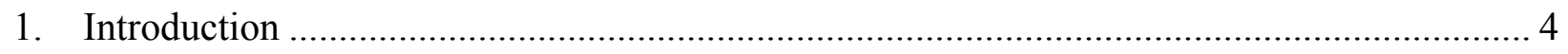

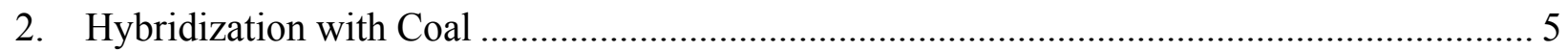

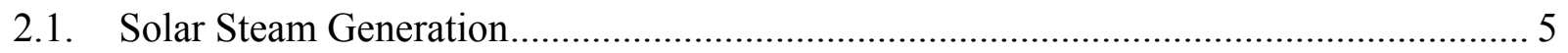

2.2. Solar-Aided Boiler Feedwater and Air Pre-Heating ....................................................... 6

2.3. Solar-Aided Post-Combustion $\mathrm{CO}_{2}$ Capture _............................................................ 9

2.4. Solar-Aided Coal Gasification with Combined Cycle ................................................... 11

2.5. Summary of Solar/Coal Hybrids ........................................................................... 13

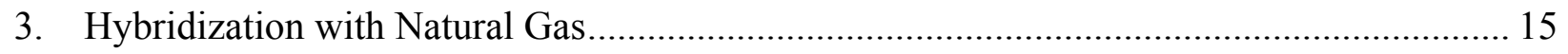

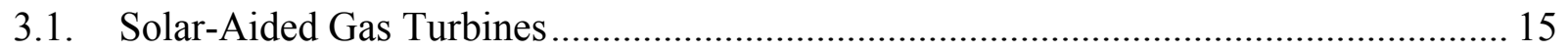

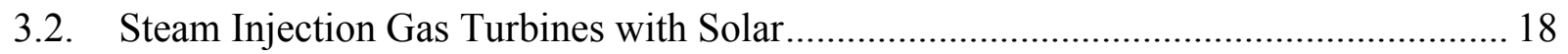

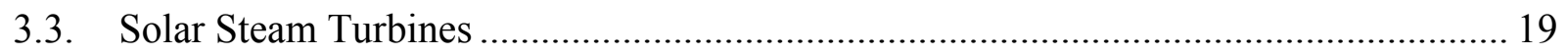

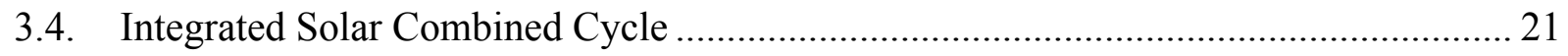

3.5. Solar Methane Steam Reforming ………………................................................... 22

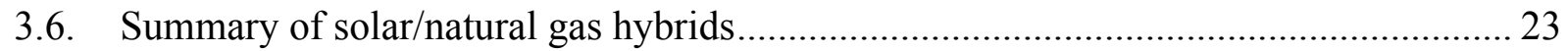

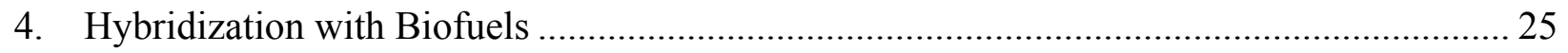

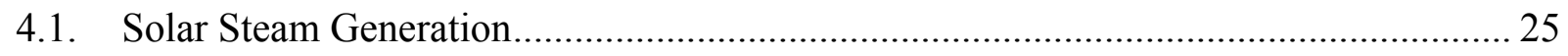

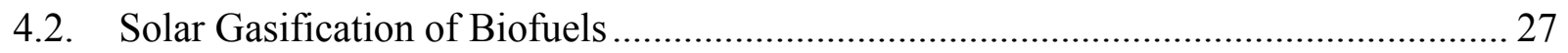

4.3. Solar-Aided Biomass Gasification with Multi-Generation ............................................ 28

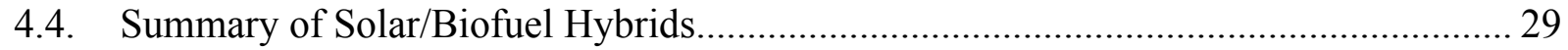

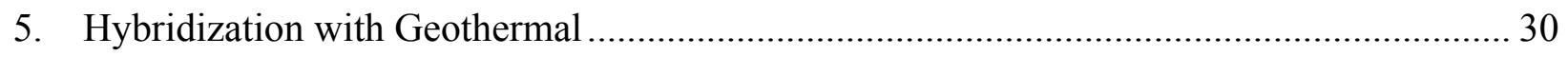

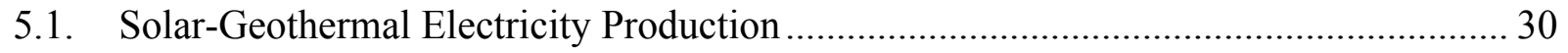

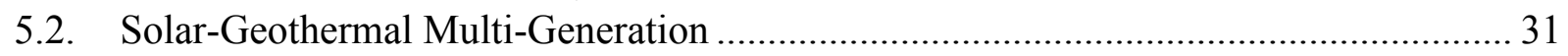

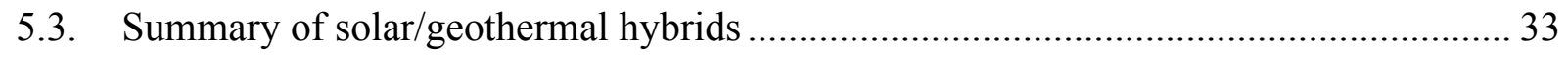

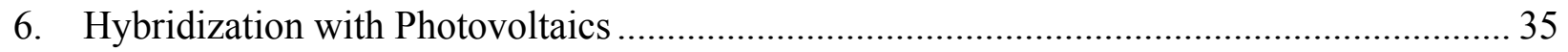

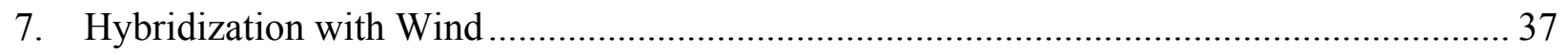

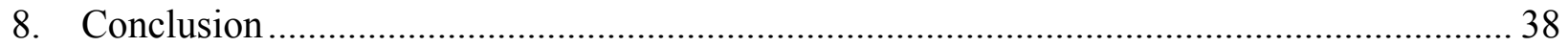

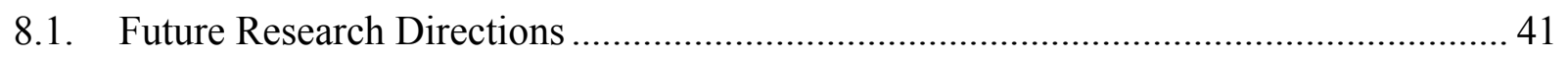

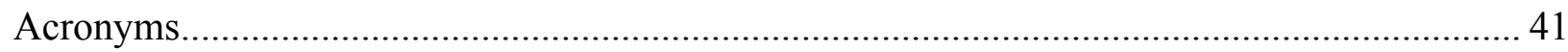

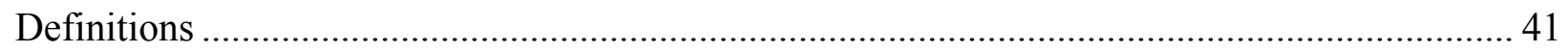

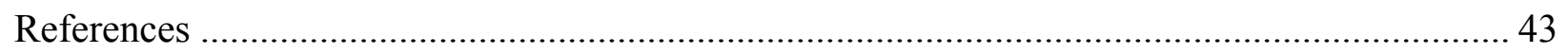




\section{Introduction}

Large-scale integration of solar energy into the electric grid presents some major technical challenges. As an intermittent energy source, solar energy requires either energy storage or fuel-based backup power so that it can provide dispatchable power (i.e., power that is available on demand). Solar photovoltaic (PV) technologies are promising for power generation, particularly with falling costs in recent years. However, because of their variable power output, widespread adoption of photovoltaics without storage may lead to grid reliability issues [1], which means that fast-ramping (and often inefficient) peaking fossil fuel technologies must be used as a backup source of power generation [2]. Alternatively, expensive battery technology may be used to increase the reliability and dispatchability of the grid.

Concentrated solar power (CSP) offers specific benefits as a renewable energy source due to the ability to readily incorporate energy storage. CSP, also known as solar thermal energy, involves heating a working fluid using concentrated sunlight. The heated fluid can then be used with conventional power generation equipment (i.e., turbines, generators, etc.) to produce electricity. The use of solar heat as an energy source in CSP makes low-cost energy storage feasible as heat can be readily stored with thermal energy storage (TES), which requires heating of a storage material and containing it in an insulated tank. CSP is also advantageous because of its amenability to hybridization. Aside from the thermal energy collection, the balance of a CSP plant may use conventional power generation equipment, making it easy to combine with other energy sources in ways that are synergistic, including the following:

- Reduced capital costs by sharing equipment between multiple energy sources

- Increase in dispatchability by combining renewable energy with dispatchable energy

- Increase in capacity utilization of power generation equipment

- Increase in reliability

- Opportunity for flexible operation

- Synergies between technologies enhanced by design and operation optimization

Realizing these benefits requires consideration of the hybrid energy source, hybrid plant configuration, solar collector technology selected, location, and many others. Economics and technical feasibility play a key role in selecting the best technologies for hybridization [3]. Peterseim et al. classified CSP hybrid systems by the synergies with the hybrid energy source. Lightly synergistic hybrid systems share minimal infrastructure and the operation of the two energy sources are not dependent on each other. Medium hybrid synergies occur when the components of the two systems are physically connected and share major equipment (such as a steam turbine). In light and medium synergistic systems, the CSP component plays a minor role and cannot operate without the hybrid host components to generate power; the hybrid host on the other hand, can operate independently of the CSP technology. Generally, these systems have a low solar share (the fraction of energy supplied by solar energy) as the solar heating is purely supplemental. Strongly synergistic hybrids share major equipment and have a higher solar share, making the CSP component more critical to plant operation [4].

Hybridization can take competing energy technologies and make them complementary. However, realizing the benefits of hybridization requires careful consideration of the technical 
feasibility as well as the economic and environmental benefits of a proposed system. The purpose of this review article is to highlight different energy sources with which CSP may be hybridized and provide an overview of the possible hybrid configurations, with advantages and disadvantages discussed. These energy sources include coal, natural gas, biofuels, geothermal energy, solar PV, and wind energy.

\section{Hybridization with Coal}

Hybridization of solar thermal power with coal has many benefits. Coal is an abundant, prevalent, and low-cost energy source. It therefore presents many opportunities to retrofit with supplemental solar thermal energy. Coal power plants have multiple points for injecting solar heat, such as boiler feedwater pre-heating, direct steam generation, boiler air pre-heating, and solvent regeneration in post-combustion $\mathrm{CO}_{2}$ removal [5]. Coal also provides a dispatchable fuel source to ensure reliability, while solar thermal energy can reduce the plant's overall $\mathrm{CO}_{2}$ emissions [6]. Hybridizing with coal can reduce the overall CSP plant cost, with one study indicating that a hybrid plant would only be $72 \%$ of the cost of a stand-alone solar plant and would generate over $25 \%$ more electricity [7].

\subsection{Solar Steam Generation}

Perhaps the most obvious choice for integrating solar energy into coal-fired power generation is steam generation for a typical Rankine cycle. Zhang et al. explored a dual source boiler configuration, where a molten-salt-based power tower is used in parallel with a coal-fired boiler to supplement its heat. Their design (shown in Figure 1) showed a relatively low solar fraction (defined as the fraction of energy provided to the power cycle by solar) with a maximum of $6.11 \%$, but demonstrated high solar-to-electric efficiency of $27.8 \%$ [9], whereas a typical stand-alone parabolic trough plant may achieve approximately $15-20 \%$ efficiency. Boiler steam can also be augmented with direct steam generation (where steam is created directly in the solar collector) from a linear (parabolic trough or linear Fresnel) or point concentrator (central receiver or parabolic dish) system [8]. Using an indirect configuration, with solar heat collected by parabolic trough to heat an oil heat transfer fluid, Zhai et al. developed an algorithm to determine the best location to deliver solar heat, depending on the amount of energy available at a given time. They also conducted a genetic-algorithm-based optimization study to determine the optimal design of the plant, including configurations with and without TES. Results showed a tradeoff between energy reduction (quantified by coal savings) and cost, indicating that economics still favor coal utilization over solar when a reduction in carbon emission is not incentivized [11]. A study by Wang et al. explored the use of solar heat augmentation of a coal power plant for temperatures ranging from 140 to $391{ }^{\circ} \mathrm{C}$. The steam generation configuration produced steam and electricity in parallel to the coal-fired unit at a solar-to-electric efficiency of $22.7 \%$. This configuration used a heat transfer fluid (presumably a thermal oil) to provide heat for a steam generator via a heat exchanger [12]. 


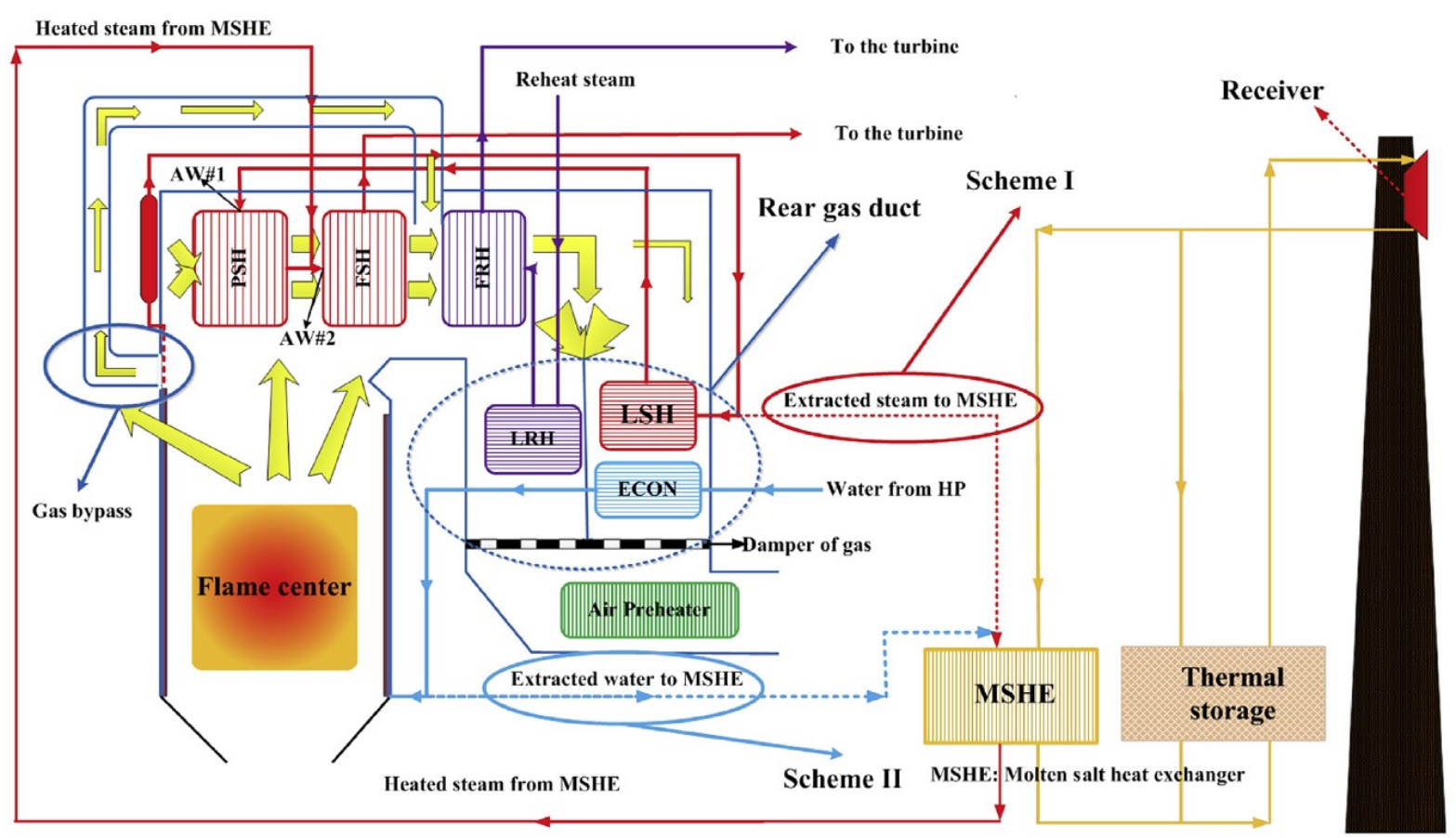

Figure 1: A dual-source boiler configuration with a molten-salt-based power tower used in parallel with coalfired heat to produce steam [9].

Solar steam generation to augment coal power is a promising method to efficiently extract solar energy. The well-developed parabolic trough solar collector technology is typically limited to temperatures below $400{ }^{\circ} \mathrm{C}$, which limits the efficiency of the power cycle. By hybridizing with coal, solar heat can be collected and used for steam generation at these temperatures, but can rely on coal combustion to achieve superheat temperatures in excess of $500{ }^{\circ} \mathrm{C}$ to increase the steam cycle's efficiency. One of the technical challenges of this concept is that the addition of solar-generated steam to existing coal boilers may cause imbalances in the steam cycle. For example, a high percentage of the steam delivered by solar would cause the coal-firing rate to decrease and would limit the coal-generated steam. The decrease in coal-firing would result in less heat available for superheating. Because of these issues, the solar fractions proposed in the literature are generally quite small (less than 10\%). Achieving higher solar fractions, therefore, will require innovative new designs (such as that shown in Figure 1 [9]) where the location of heat delivery in the steam cycle can be changed via the combustion gas bypass, depending on the conditions and the amount of solar heat available.

\subsection{Solar-Aided Boiler Feedwater and Air Pre-Heating}

Another means of adding solar heat to a coal plant is by pre-heating the boiler feedwater (see Figure 2). Compared to solar steam generation in a solar-coal hybrid, the literature is more replete with studies on boiler feedwater preheating. This configuration allows for heat to be collected at lower temperatures, which reduces the solar field heat losses that are proportional to temperature, and can avoid the use of phase change in the solar collector (direct steam generation) or an HTF-to-steam heat exchanger. The use of solar boiler feedwater preheating in a coal plant would have the effect of increasing the power output of the plant, as feedwater 
preheating would likely otherwise be done by extracting valuable steam from the turbines to mix with the feedwater, which in turn decreases the power output. This method results in lower thermal losses in the collector field by operating it at a lower temperature (near or below $300{ }^{\circ} \mathrm{C}$ ). Coal combustion in the boiler is then used to create superheated steam and ensure a more efficient steam cycle. One of the benefits of this configuration is that coal combustion can be used to provide system flexibility to help the plant maintain stability under fluctuating solar energy availability or transient demand and may not require large storage systems. A study by $\mathrm{Wu}$ et al. determined that the optimal storage capacity for this configuration was only 0.5 hours [13]. Although a short storage duration was deemed optimal in this study, other studies have indicated that TES, combined with an oversized solar field, can be used to increase the solar fraction of the plant [14].

Studies on solar-aided boiler feedwater preheating have demonstrated an improved solarto-electricity efficiency, when compared to stand-alone plants. An investigation by Zhao et al. demonstrated that a boiler feedwater pre-heating configuration resulted in a $21.2 \%$ solartoelectricity efficiency, as compared to $19.4 \%$ in a stand-alone solar thermal plant [15]. Using a similar configuration for boiler feedwater preheating with parabolic trough technology, Hong et al. reported a similar increase in efficiency, going from $18 \%$ in a stand-alone solar plant to $21 \%$ in a plant hybridized with coal. Hybridization also increased the plant capacity factor slightly from $22.3 \%$ to $23.8 \%$. Presumably, the capacity factor would be much higher if the plant were operated in coal-only mode at night [16]. A later study showed solar-to-electricity efficiency as high as $27.3 \%$ for the hybrid configuration as compared to $25.9 \%$ for a solar-only plant [17], although Zhai et al. reported lower solar-to-electric efficiencies of $13.6 \%$ in a similar configuration [18]. Feng et al. explored direct steam generation for a solar-aided power generation system with coal, where the solar-produced steam was combined with turbine extraction steam and used for boiler feedwater pre-heating. The study explores injecting the steam at different stages of extraction and finds that net solar thermal efficiencies up to $28.5 \%$ are possible [10].

Injecting solar heat for boiler feedwater pre-heating can be done at different temperatures and pressures. A study by Wang et al. determined that high pressure boiler feedwater heating was more efficient at $24.1 \%$ (solar-to-electric) than when done at low pressure (11.4\%) [12]. The highest efficiency reported in the literature for solar-aided boiler feedwater pre-heating was $40.3 \%$ by Yan et al., who explored several different configurations and plant sizes with solar acting in both power-boosting or fuel-saving mode [20]. In addition to increasing the efficiency and the capacity factor solar levelized cost of electricity (LCOE) can be minimized by optimizing the plant design [19]. It should be noted that evaluation methods for determining solar-to-electric efficiency and the solar contribution to hybrid solar/coal plants vary, so results should not always be taken at face value, but should be examined in the context of the method the authors use for determining efficiency and solar contribution [21]. 


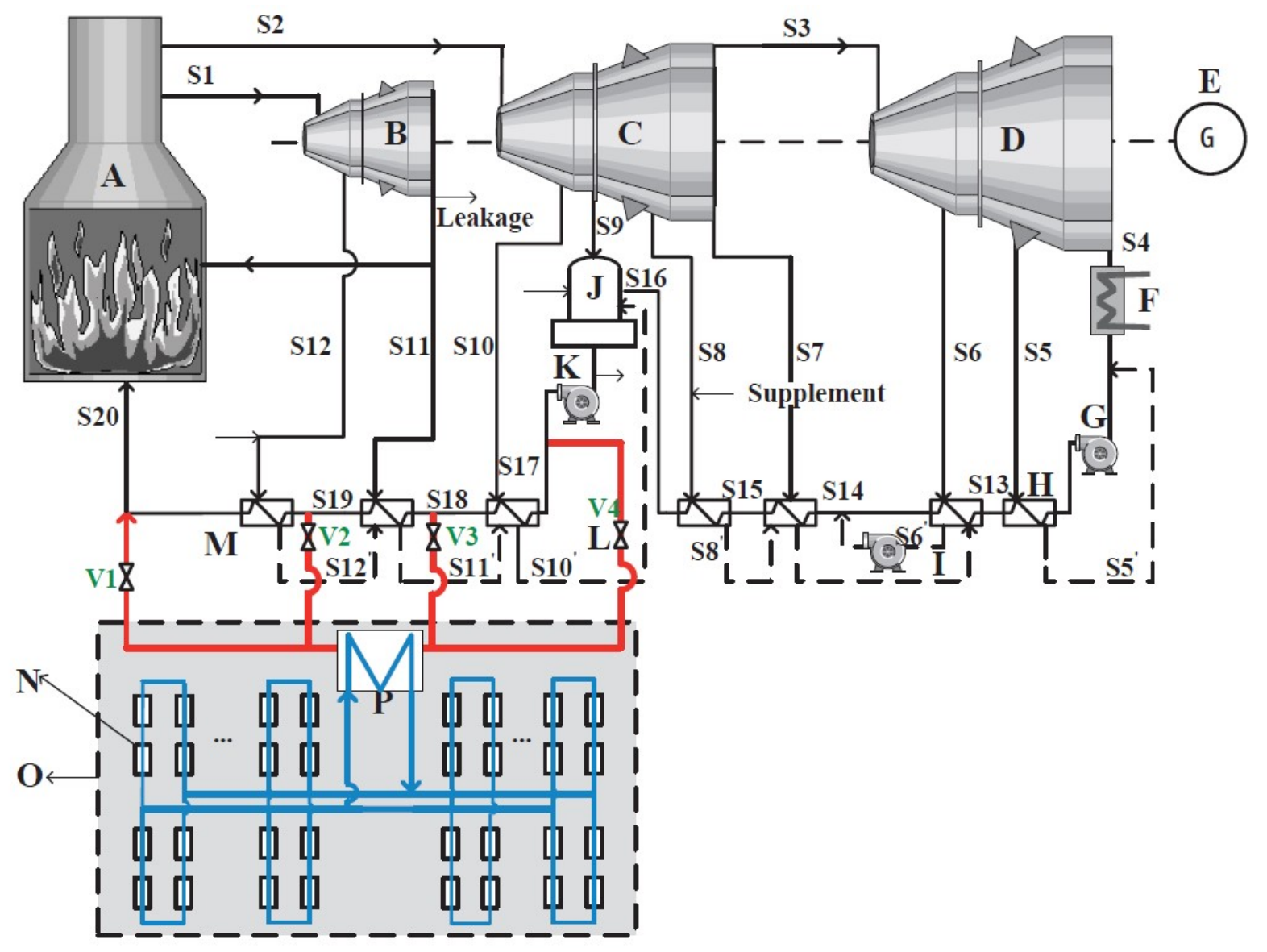

Figure 2: A schematic demonstrating the use of a parabolic trough solar field to provide boiler feedwater preheating to a coal boiler. Components are labeled as follows: A-Coal-fired boiler; B-High-pressure steam turbine; C-Mid-pressure steam turbine; D-Low-pressure steam turbine; E-Generator; F-Condenser; GCondensate pump; H-Low-pressure feed-water heater; I-Drain pump; J-Deaerator; K-High-pressure pump; L-Valve; M-High-pressure feed-water heater; N-parabolic trough collectors; O-Solar feed-water heater; PWater-oil heat exchanger. Available from [22].

Another boiler preheating concept that has been investigated uses circulating particles to collect solar heat at higher temperatures (over $500^{\circ} \mathrm{C}$ ) in a central receiver configuration. Using this heat collection methodology to pre-heat air as an additional heat source in a coal-fired boiler, Prosin et al. reported solar-to-electric efficiencies of up to $22.3 \%$ when the air is heated to $540{ }^{\circ} \mathrm{C}$ and recirculated to the receiver [23]. 


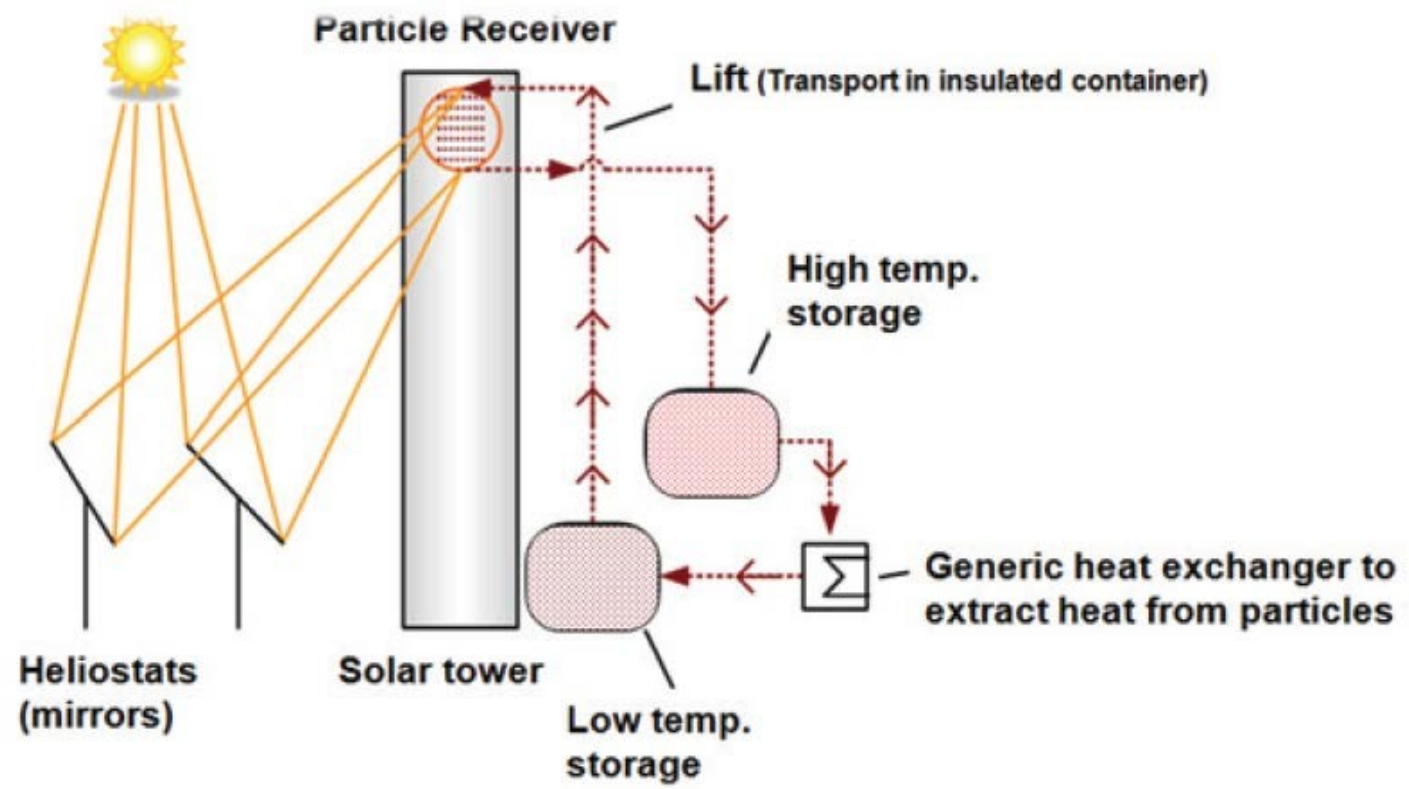

Figure 3: Power tower with solid particle receiver concept to pre-heat the boiler air in a solar/coal hybrid [23].

Both preheating concepts (air and feedwater) can demonstrate higher solar-to-electric efficiencies than stand-alone CSP plants. One of the key reasons these concepts are more efficient is because they collect solar heat at lower temperatures (thereby reducing heat losses on the solar collector), while relying on coal combustion to generate higher temperature heat for steam generation and superheating. This reliance limits the solar fraction of the plant, with studies indicating a maximum instantaneous solar fraction of $30 \%$ (as seen in Table 1) and an annual solar fraction generally expected to be much lower than that (absent an oversized solar field and a TES system). This concept, therefore, may present an effective method to harvest solar energy, but which may be limited in the scale at which it is able to be collected.

\subsection{Solar-Aided Post-Combustion $\mathrm{CO}_{2}$ Capture}

Post-combustion carbon capture processes, if/when developed on a large scale will present another opportunity to integrate solar heat into coal power systems. A predominant technology in $\mathrm{CO}_{2}$ removal uses an absorber/stripper combination [24]. In this configuration, the power plant flue gas is fed to an absorber column where a solvent, normally monoethanolamine (MEA) is used to absorb $\mathrm{CO}_{2}$ from the stream. The $\mathrm{CO}_{2}$-rich solvent stream is then sent to a stripper column, where heat is used to drive the absorbed $\mathrm{CO}_{2}$ from the liquid, which regenerates the solvent so that it can be recycled back to the absorber column $[25,26]$. Because of the heat required to regenerate the solvent, this process requires additional energy, which typically would come from extracting steam from the plant's turbines. This is viewed as an energy penalty to the power plant and is estimated to be around $20 \%$ of the plant's total power output [27-30]. Solar thermal energy has been identified as a potential source for this heat requirement and has the benefit of removing $\mathrm{CO}_{2}$ from the environment using a renewable source of energy. This methodology has been proven to be effective, as Wang et al. experimentally demonstrated nearly 
$75 \% \mathrm{CO}_{2}$ removal using solar-assisted post-combustion $\mathrm{CO}_{2}$ removal technology [31]. An indepth review of solar-assisted carbon capture is given in [32].

One benefit of using solar thermal heat in the $\mathrm{CO}_{2}$ removal process is that it does not require high temperatures. Linear solar energy collection technologies (parabolic trough and Fresnel) are generally sufficient. Zhao et al. demonstrated that solar thermal heat at temperatures below $300^{\circ} \mathrm{C}$ can be effectively used for solvent regeneration in post-combustion $\mathrm{CO}_{2}$ removal (see Figure 4). The study found that a solar-to-electric efficiency of up to $27 \%$ can be achieved, using the saved power from the coal plant as a surrogate for power actually generated from the solar thermal technology [33]. Wang et al. proposed solar heat collection at $145{ }^{\circ} \mathrm{C}$ for solvent regeneration in $\mathrm{CO}_{2}$ removal system. Temperatures that low could also be achieved using a non-concentrating, evacuated tube solar collection system [12], which could result in lower capital costs.

Proposing a hybrid system that includes coal, natural gas, and solar thermal, Brodrick et al. completed an optimization study that used steam extraction from a natural gas combined cycle plant augmented with solar-generated steam to provide heat for solvent regeneration used in post-combustion $\mathrm{CO}_{2}$ removal from coal power plant flue gas. They concluded that high natural gas prices are required for the inclusion of solar thermal heat to be a viable economic option [34]. Carapellucci et al. studied the use of CSP technology to provide an additional energy source for $\mathrm{CO}_{2}$ removal from a coal-fired power plant. In their study, a $100 \mathrm{MW}_{\mathrm{e}}$ coal plant would require 65.7 $\mathrm{MW}_{\text {th }}$ for solvent (MEA) regeneration, which would normally be supplied by extracting steam from a turbine, and would result in reduced power consumption of the plant from 100 to 79.1 $\mathrm{MW}_{\mathrm{e}}$. Their study concluded that CSP could supply up to $80 \%$ of this parasitic load and reduce the heat rate of the plant by $12 \%$ [35]. In a techno-economic assessment of solarassisted post-combustion carbon capture (SPCC), Qadir et al. determined that a carbon price of \$44/tonne- $\mathrm{CO}_{2}$ would be required to make SPCC plants economical compared to conventional, non-carbon capture plants, with solar fractions of up to $80 \%$ being economically feasible in some areas under these circumstances [36].

Thermal energy storage can also be integrated into the carbon capture process to ensure a higher solar fraction [37]. An economic and policy study showed that the combination of a $\$ 25 /$ tonne- $\mathrm{CO}_{2}$ with a $\$ 35 / \mathrm{MWh}_{\mathrm{e}}$ would make this technology economically viable in some areas [38]. The economics of this methodology can become quite complex and rely on a number of different factors including fuel prices, equipment prices, age of the plant, policy factors, and available subsidies [39]. 


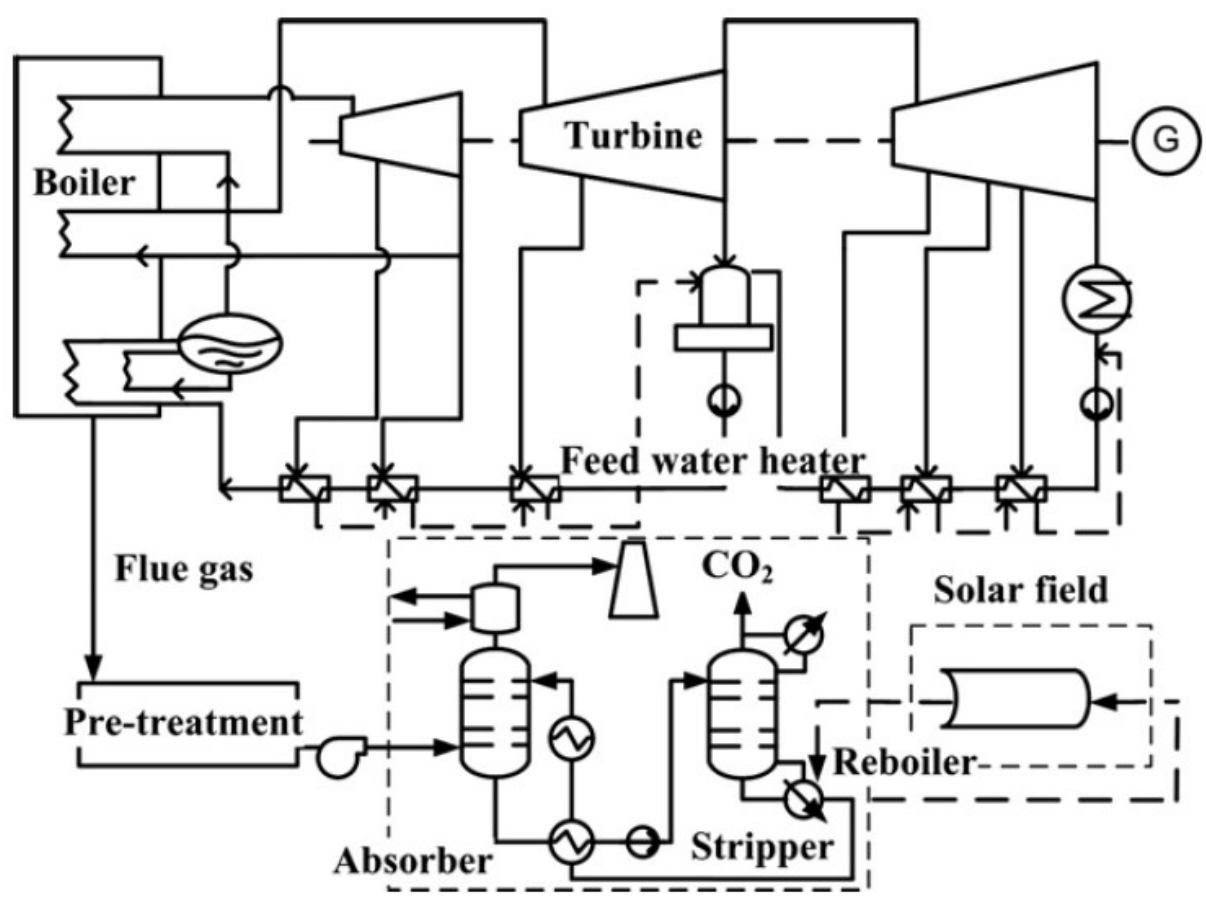

Figure 4: Post-combustion $\mathrm{CO}_{2}$ removal from a coal-fired power plant using solar heat [33].

Another synergistic benefit in using solar thermal heat for $\mathrm{CO}_{2}$ removal is that the addition of post-combustion carbon capture technology and solar thermal technology would each represent retrofits to existing coal-fired power plants that could be completed simultaneously. The addition of this combined technology would presumably have less impact on the existing coal plant operation, as it would only need connection to the flue gas stream from the plant. Like preheating, solar thermal heat for $\mathrm{CO}_{2}$ removal increases the power output of the plant by lessening the need to extract heat from elsewhere (e.g., from the steam turbines) and presents an opportunity to utilize lower temperature solar heat.

\subsection{Solar-Aided Coal Gasification with Combined Cycle}

Integrated gasification combined cycle (IGCC) power plants combine the efficiency benefits of a combined cycle power plant with an abundant fuel source in coal. In a gasification process, a carbonaceous fuel (coal, petroleum coke, biomass, etc.) undergoes only a partial oxidation (unlike full oxidation in a combustion process) by being exposed to a limited amount of oxygen in a high-temperature and high-pressure environment. This exothermic reaction produces a $\mathrm{CO}$ and $\mathrm{H}_{2}$ syngas, which can be used in a variety of ways (e.g., hydrogen production [40], chemical production, conversion to liquid fuels via gas-to-liquids process, etc.) [41-43]. In the case of IGCC, the syngas is combusted in a gas turbine with the waste heat recovery used to run the steam cycle [44]. In addition to the efficiency of using a combined cycle rather than a simple steam cycle, IGCC has several other environmental benefits including pre-combustion removal of harmful pollutants [45]. Because gasification processes require a heat source that is usually provided by partial consumption of the carbonaceous fuel itself, it can be augmented with solar thermal power to reduce the fuel consumption and make the process more environmentally friendly [37,46-51]. 
$\mathrm{Ng}$ and Lipiński performed a thermodynamic analysis of an integrated gasification and combined cycle power plant, which was hybridized with solar thermal energy as a heat source [52]. Their configuration (shown in Figure 5) uses solar heat in two locations: direct heating of the gasification reactor at $1077^{\circ} \mathrm{C}$ (by power tower, STR in Figure 5) and steam production in the solar steam generator (SSG) at $100{ }^{\circ} \mathrm{C}$ (by parabolic trough). Compared to a conventional coal-fired Rankine cycle power plant, $\mathrm{CO}_{2}$ emissions are reduced by $47 \%$ using this configuration. An alternative configuration by Ozturk and Dincer uses a molten-salt-based power tower to generate steam for the coal gasifier with the syngas fueling an IGCC [53]. This multigeneration system includes syngas storage and simultaneously produces hydrogen, hot water, heating and cooling. Shrivastava and Prabu took the concept of solar-augmented coal gasification for power production one step further. One of their proposed configurations uses solar-generated steam for underground coal gasification. The produced syngas is then burned and undergoes heat exchange with a $\mathrm{CO}_{2}$ stream that is used in a super-critical Brayton cycle to produce electricity. A separate solar field is used to pre-heat the $\mathrm{CO}_{2}$ stream. Their design uses 81.5 MW of solar heat compared to $279.3 \mathrm{MW}$ of coal heat. Including an energy penalty for carbon capture and storage, the system has a net thermal efficiency of $32.9 \%$ [54].

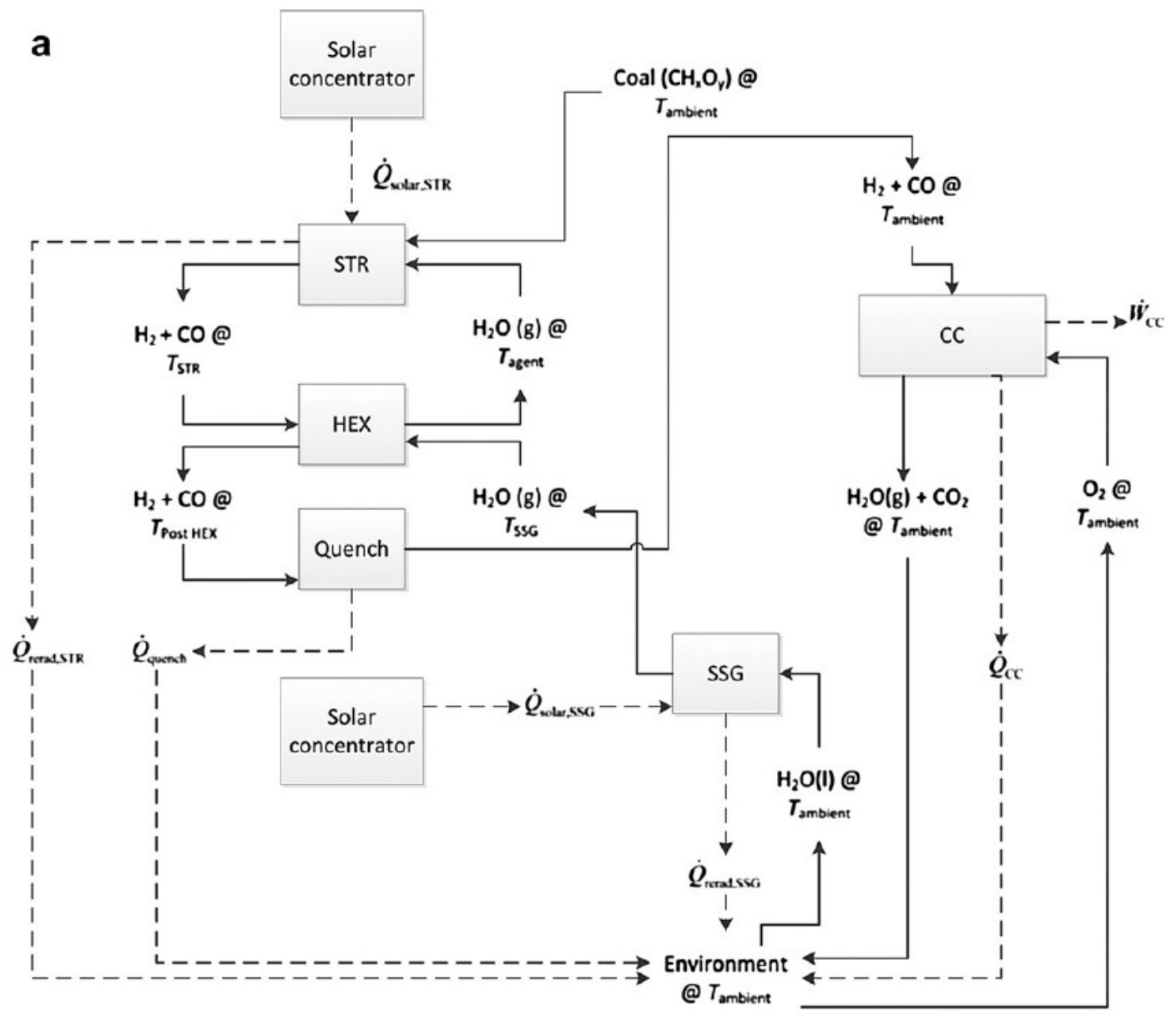


Figure 5: Process flow diagram for a solar-assisted integrated gasification and combined cycle process. $\mathrm{STR}=$ solar thermal reactor (gasifier), $\mathrm{HEX}=$ heat exchanger, $\mathrm{SSG}=$ solar steam generator, $\mathrm{CC}=$ combined cycle [52].

\subsection{Summary of Solar/Coal Hybrids}

The various methods for combining CSP with coal are presented in Table 1, which summarizes critical details of some of the studies (those that explicitly contain the majority of information used for comparison). Hybridizing coal plants with CSP has several key advantages including the fact that coal has historically been an abundant and low-cost fuel source, and there are many opportunities for retrofitting existing coal plants with solar. As a combustible fuel source, coal provides reliability and dispatchability for solar and studies have demonstrated higher solar-to-electric efficiency for solar. One of the key disadvantages of CSP-coal hybrids, however, includes the fact that many existing coal plants are relatively old, which may create an equipment age mismatch if the plants were to be retrofitted with solar. Coal plants approaching their end of life may make an incremental investment in CSP uneconomical.

Table 1: A summary of CSP-coal hybrid systems.

\begin{tabular}{|c|c|c|c|c|c|}
\hline Configuration & $\begin{array}{l}\text { Solar } \\
\text { Collection } \\
\text { Temp. } \\
\end{array}$ & $\begin{array}{l}\text { Collector } \\
\text { Type }\end{array}$ & $\begin{array}{l}\text { Solar heat } \\
\text { collection } \\
\text { fluid }\end{array}$ & $\begin{array}{l}\text { Solar } \\
\text { fraction }\end{array}$ & $\begin{array}{l}\text { Solar- } \\
\text { toelectricity } \\
\text { efficiency }\end{array}$ \\
\hline \multicolumn{6}{|l|}{ Solar Steam Generation } \\
\hline $\begin{array}{l}\text { Molten salt power tower with } \\
\text { storage produces steam in } \\
\text { parallel with coal boiler [9] }\end{array}$ & $571^{\circ} \mathrm{C}+$ & $\begin{array}{l}\text { Power } \\
\text { Tower }\end{array}$ & $\begin{array}{l}\text { Molten Salt } \\
\text { (binary } \\
\text { nitrate) }\end{array}$ & $\begin{array}{l}6.1 \% \\
(\max )\end{array}$ & $27.8 \%$ \\
\hline $\begin{array}{l}\text { Direct steam generation in } \\
\text { line focus receiver for high } \\
\text { pressure superheated steam } \\
\text { production [8] }\end{array}$ & $500^{\circ} \mathrm{C}$ & Line Focus & $\begin{array}{l}\text { Direct Steam } \\
\text { Generation }\end{array}$ & - & $38-45 \%$ \\
\hline $\begin{array}{l}\text { Direct steam generation in } \\
\text { central receiver for high } \\
\text { pressure superheated steam } \\
\text { production [8] }\end{array}$ & $565^{\circ} \mathrm{C}$ & $\begin{array}{l}\text { Central } \\
\text { Receiver }\end{array}$ & $\begin{array}{l}\text { Direct Steam } \\
\text { Generation }\end{array}$ & - & $38-45 \%$ \\
\hline \multicolumn{6}{|l|}{ Feedwater Preheating } \\
\hline $\begin{array}{l}\text { PT solar field with VP1 used } \\
\text { for boiler feedwater } \\
\text { preheating [15] }\end{array}$ & $267^{\circ} \mathrm{C}$ & $\begin{array}{l}\text { Parabolic } \\
\text { Trough }\end{array}$ & $\begin{array}{l}\text { Therminol } \\
\text { VP1 }\end{array}$ & - & $\begin{array}{l}21.2 \% \\
(\max )\end{array}$ \\
\hline $\begin{array}{l}\text { PT solar field with } \\
\text { Dowtherm A used for boiler } \\
\text { feedwater pre-heating [16] }\end{array}$ & $292^{\circ} \mathrm{C}$ & $\begin{array}{l}\text { Parabolic } \\
\text { Trough }\end{array}$ & Dowtherm A & - & $\begin{array}{l}21 \% \\
\text { (annual) }\end{array}$ \\
\hline $\begin{array}{l}\text { PT solar field with } \\
\text { Dowtherm A used for boiler } \\
\text { feedwater pre-heating [17] }\end{array}$ & $292^{\circ} \mathrm{C}$ & $\begin{array}{l}\text { Parabolic } \\
\text { Trough }\end{array}$ & Dowtherm A & - & $27.3 \%$ \\
\hline
\end{tabular}




\begin{tabular}{|c|c|c|c|c|c|}
\hline $\begin{array}{l}\text { PT solar field with thermal } \\
\text { oil used for boiler feedwater } \\
\text { pre-heating [20] }\end{array}$ & $\begin{array}{l}260^{\circ} \mathrm{C} \\
(\max )\end{array}$ & $\begin{array}{l}\text { Parabolic } \\
\text { Trough }\end{array}$ & Thermal Oil & $\begin{array}{l}10.3 \% \\
(\max )\end{array}$ & $\begin{array}{l}40.3 \% \\
(\max )\end{array}$ \\
\hline $\begin{array}{l}\text { Direct steam generation in } \\
\text { parabolic trough combined } \\
\text { with turbine extraction steam } \\
\text { for BFW pre-heating [10] }\end{array}$ & $398.1^{\circ} \mathrm{C}$ & $\begin{array}{l}\text { Parabolic } \\
\text { Trough }\end{array}$ & $\begin{array}{l}\text { Direct Steam } \\
\text { Generation }\end{array}$ & - & $28.5 \%$ \\
\hline $\begin{array}{l}\text { Thermal oil-heated in PT for } \\
\text { BFW Pre-heating [18] }\end{array}$ & $387^{\circ} \mathrm{C}$ & $\begin{array}{l}\text { Parabolic } \\
\text { Trough }\end{array}$ & Thermal Oil & $5.77 \%$ & $13.6 \%$ \\
\hline $\begin{array}{l}\text { Thermal oil heated in PTC } \\
\text { for BFW pre-heating [13] }\end{array}$ & $283^{\circ} \mathrm{C}$ & $\begin{array}{l}\text { Parabolic } \\
\text { Trough }\end{array}$ & Thermal Oil & - & $\begin{array}{l}21 \% \\
\text { (annual) }\end{array}$ \\
\hline $\begin{array}{l}\text { PTC used to heat Thermal oil } \\
\text { for LP BFW pre-heating [12] }\end{array}$ & $140^{\circ} \mathrm{C}$ & $\begin{array}{l}\text { Parabolic } \\
\text { Trough } \\
\text { (or } \\
\text { evacuated } \\
\text { tube) }\end{array}$ & Thermal Oil & $\begin{array}{l}\sim 30 \% \\
(\max )\end{array}$ & $11.4 \%$ \\
\hline $\begin{array}{l}\text { PTC used to heat Thermal oil } \\
\text { for HP BFW pre-heating } \\
\text { [12] }\end{array}$ & $282^{\circ} \mathrm{C}$ & $\begin{array}{l}\text { Parabolic } \\
\text { Trough }\end{array}$ & Thermal Oil & $\begin{array}{l}\sim 29 \% \\
(\max )\end{array}$ & $24.1 \%$ \\
\hline \multicolumn{6}{|l|}{ Air Preheating } \\
\hline $\begin{array}{l}\text { Boiler air pre-heating with } \\
\text { solid particle receiver [23] }\end{array}$ & $540^{\circ} \mathrm{C}$ & $\begin{array}{l}\text { Power } \\
\text { tower }\end{array}$ & $\begin{array}{l}\text { Air with } \\
\text { ceramic } \\
\text { particles }\end{array}$ & $7.8 \%$ & $\begin{array}{l}22.3 \% \\
(\max )\end{array}$ \\
\hline \multicolumn{6}{|c|}{ Gssification } \\
\hline $\begin{array}{l}\text { Power tower that makes steam } \\
\text { for coal gasification } \\
\text { [53] }\end{array}$ & $650^{\circ} \mathrm{C}$ & $\begin{array}{l}\text { Power } \\
\text { Tower }\end{array}$ & Molten Salt & - & - \\
\hline $\begin{array}{l}\text { Direct heating of gasification } \\
\text { reactor before combined } \\
\text { cycle [52] }\end{array}$ & $1077^{\circ} \mathrm{C}$ & $\begin{array}{l}\text { Power } \\
\text { Tower }+ \\
\text { Parabolic } \\
\text { Trough }\end{array}$ & $\begin{array}{l}\text { Reactant } \\
\text { gases (steam/ } \\
\left.\mathrm{CO}_{2}\right)+ \\
\text { Direct Steam } \\
\text { Generation }\end{array}$ & $31 \%(\max )$ & - \\
\hline $\begin{array}{l}\text { Parabolic trough makes } \\
\text { steam for gasification and } \\
\text { pre-heats } \mathrm{CO}_{2}[54]\end{array}$ & $\begin{array}{l}142.9^{\circ} \mathrm{C} \\
(\text { steam }) / \\
198.9^{\circ} \mathrm{C} \\
\left(\mathrm{CO}_{2}\right)\end{array}$ & $\begin{array}{l}\text { Parabolic } \\
\text { Trough }\end{array}$ & $\begin{array}{l}\text { Direct steam } \\
\text { generation / } \\
\text { supercritical } \\
\mathrm{CO}_{2}\end{array}$ & $22.6 \%$ & - \\
\hline \multicolumn{6}{|l|}{$\mathrm{CO}_{2}$ Capture } \\
\hline $\begin{array}{l}\text { PTC used to heat Thermal oil } \\
\text { for solvent regeneration in } \\
\mathrm{CO}_{2} \text { capture [12] }\end{array}$ & $145^{\circ} \mathrm{C}$ & $\begin{array}{l}\text { Parabolic } \\
\text { Trough/ } \\
\text { evacuated } \\
\text { tube }\end{array}$ & Thermal Oil & $\begin{array}{l}\sim 29 \% \\
(\max )\end{array}$ & $15.3 \%$ \\
\hline $\begin{array}{l}\text { PT solar field with VP1 to } \\
\text { provide heat to stripper in } \\
\text { post-combustion } \mathrm{CO}_{2} \\
\text { separation [33] }\end{array}$ & $295^{\circ} \mathrm{C}$ & $\begin{array}{l}\text { Parabolic } \\
\text { Trough }\end{array}$ & $\begin{array}{l}\text { Therminol } \\
\text { VP1 }\end{array}$ & $27.6 \%$ & $27 \%$ \\
\hline
\end{tabular}




\section{Hybridization with Natural Gas}

Natural gas has been labeled as a transition fuel because it provides the reliability, low cost, and dispatchability of fossil fuels, but has much lower $\mathrm{CO}_{2}$ emissions than coal due to the low carbon-to-hydrogen ratio of its molecular structure (predominantly $\mathrm{CH}_{4}$ ). Like coal, there are many different ways that natural gas power generation technology can be hybridized with concentrated solar power technology.

\subsection{Solar-Aided Gas Turbines}

Because gas turbines operate at significantly higher temperatures than steam turbines, injecting heat via solar requires higher temperatures (typically above $1000{ }^{\circ} \mathrm{C}$ ), which presents some technical challenges on the collector end. However, by replacing high temperature heat that is typically delivered by natural gas, the solar-aided gas turbine concept has the potential to achieve high solar shares, whereas other configurations, such as solar steam generation on the back end of a combined cycle plant, will always rely on the fossil fuel as the primary heat source. Gas turbine power generation utilizes the Brayton cycle and typically operates as an open system, where atmospheric air is compressed, heated by the combustion of natural gas (or another gaseous fuel), and exhausted through a turbine that produces mechanical power, which is then converted to electricity by a generator. The operational flexibility provided by gas turbines makes them valuable to pair with a variable energy source, such as solar thermal energy [55]. The ability for flexible operation is the result of adjustable natural gas flow and air flow via inlet guide vanes which allow the turbine operation to adjust to variable solar conditions [56]. Solar heat would typically be added to the cycle post-compression and pre-combustion, where the use of fuel combustion can assure that the system can reach adequate operating temperatures, regardless of the amount of sunlight available at a particular time.

Thermal energy storage can also be used to increase the solar fraction of the plant. Cost effective TES can be achieved in a packed-bed configuration with a storage efficiency of up to $88 \%$ [57]. TES in this (or a similar) configuration can dramatically improve the solar fraction of the plant as it allows for a larger solar multiple with the excess energy being stored for later use [58].

The direct use of solar energy for a Brayton cycle power plant operation, where the air stream is directly heated by a solar receiver, typically requires the use of a pressurized receiver, as the best opportunity to add solar heat is generally post-compression. This generally requires much higher temperatures than Rankine cycle operation. The concept has been proven at MW scale. The Solugas receiver in Spain reached outlet temperatures of over $800{ }^{\circ} \mathrm{C}$ with a temperature increase of over $500^{\circ} \mathrm{C}$ in the solar collector [59]. The Solugas system also uses gas combustion to bring the gas temperature up to $1150^{\circ} \mathrm{C}$ at a nominal operating pressure of $9 \mathrm{bar}$ [60]. Using a micro gas turbine concept with a parabolic dish, Semprini et al. explored several different turbine operating strategies in hybrid mode and compared this to stand-alone mode. Their hybrid design used a pressurized air solar receiver to heat pre-combustion air with a combustion chamber being used to supply any necessary additional heat. For a $30 \mathrm{MW}_{\mathrm{e}}$ design, hybrid operation increases the overall efficiency (annual) from 15.9\% in stand-alone mode to $19.0 \%$ in hybrid mode with one particular operating strategy. The same operating strategy 
increases the capacity factor from $29.2 \%$ to $43.5 \%$. One conclusion from their study is that, because the plant is designed to accommodate solar heat, it is advisable to limit the fuel-burning hybrid operation only to sunlight hours, as fuel-only mode at night has too high operational costs [61].

Aichmayer et al. proposed using multiple solar parabolic-dish-powered micro gas turbines in parallel with the hot exhaust gas from each being combined and fed to a heat recovery steam generator (HRSG) to produce steam for a steam cycle. This combined cycle concept demonstrated high solar shares (66.4\% nominal and 32.0\% annual), but was prohibitively expensive with LCOEs more than double that of a larger, centralized plant [62]. This concept may have other benefits, such as modularity, however, to make it advantageous in certain circumstances. The same authors also explored simple cycle operation of solar dish / micro gas turbine systems with recuperation. Two configurations (shown in Figure 6) were explored: (a) the use of a pressurized receiver for direct heating of the gas stream and (b) an atmospheric receiver and combustor to indirectly heat the stream via heat exchange. Although the focus of the research was on the design of the receivers themselves, the system was also analyzed and predicted an overall efficiency of nearly $30 \%$ [63]. In addition to the receiver design, the combustor design in solar-heated gas turbines is also important, as conventional combustors have not been designed to accept high temperature inlet conditions [64] and rigorous modeling of the combustor via computational fluid dynamics (CFD) or other methods can be beneficial $[65,66]$. In a similar work, a pressurized, dish-based solar receiver with a micro gas turbine studied by Ragnolo et al. predicted an overall efficiency of $29.6 \%$ [67].

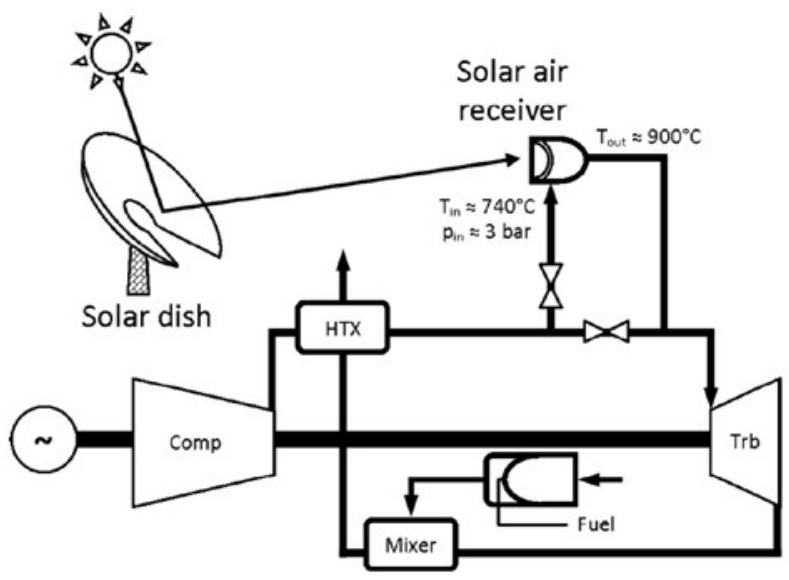

(a)

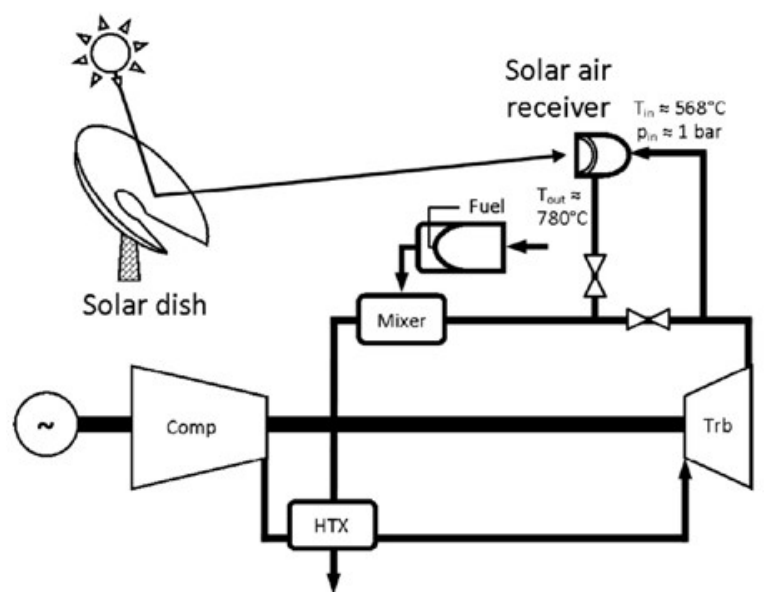

(b)

Figure 6: Solar / gas turbine configurations using (a) a pressurized receiver (post heat recuperation) and (b) an atmospheric receiver that re-heats the exhaust air to supplement heat recuperation [63].

The efficiency of solar-heated simple cycle gas turbines can also be increased with heat recuperation where the waste heat from the flue gas is used to pre-heat the air prior to entering the solar heater section [68]. A study on the use of a falling particle receiver for air heating in this configuration predicted overall efficiencies of up to $35.3 \%$ [69]. Santos et al. concluded that 
using recuperation results in fuel savings of up to $11.7 \%$ in summer months, while this number is significantly lower in the winter months (4\%) [70].

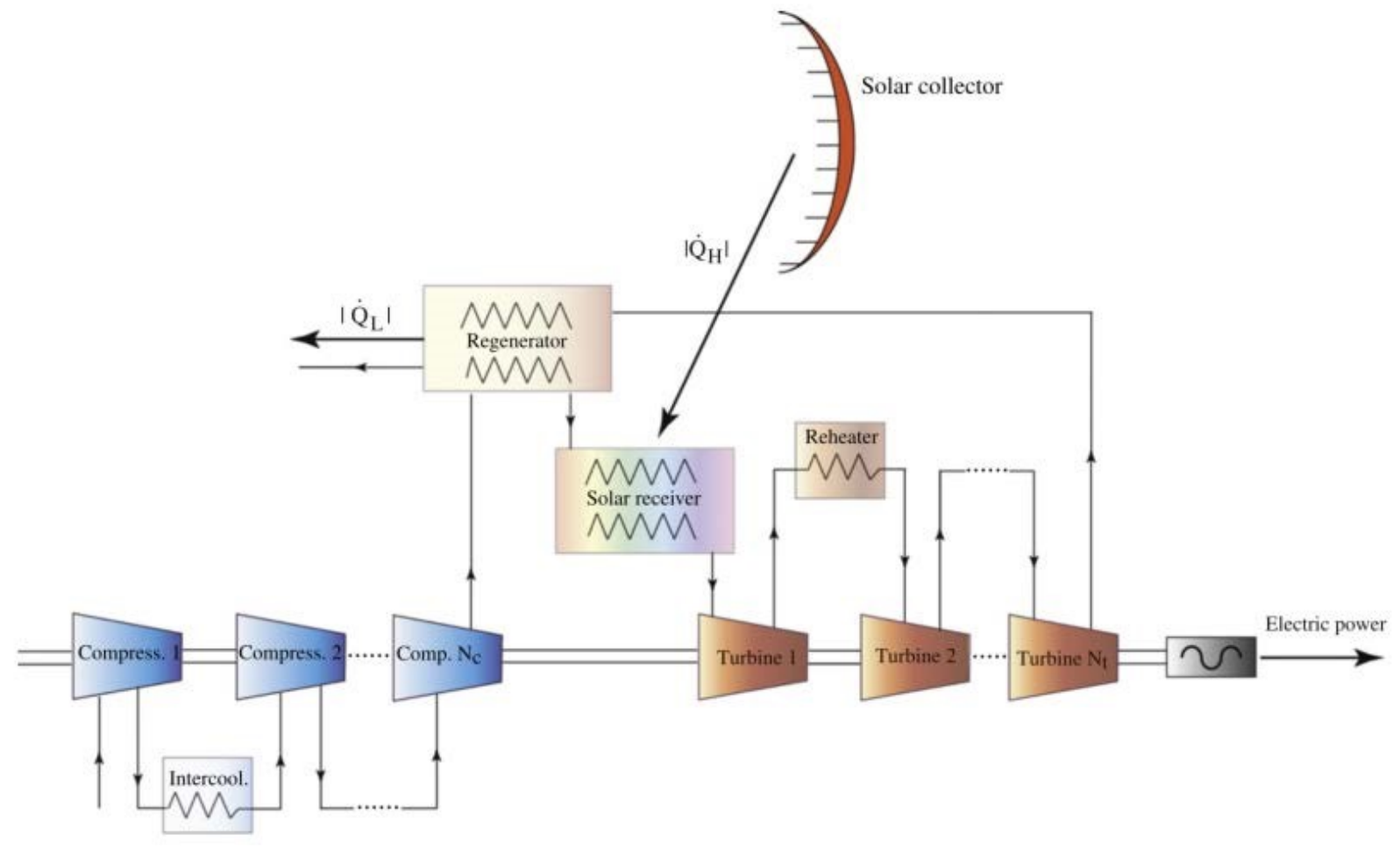

Figure 7: A recuperated solar gas turbine [68].

Mokheimer et al. proposed a solar heated (power tower) gas turbine system that would heat air to nearly $1000^{\circ} \mathrm{C}$ using a gas turbine for power production. An HRSG is then used to produce steam in a cogeneration setting, although the steam conditions were suitable for additional power generation via combined cycle. This configuration demonstrated an instantaneous solar share of $74.2 \%$ and an annual solar share of $31.5 \%$ [71].

Another option for solar and natural gas hybrid gas turbines is to use an externally-fired gas turbine. This re-emerging technology was thoroughly reviewed by Al-attab and Zainal and has some benefits for solar thermal power generation including the ability to use a closed Brayton cycle by firing the fuel separately from the cycle gas stream and using a heat exchanger to deliver the heat [72]. Olivenza-León et al. proposed a closed Brayton cycle that uses an atmospheric receiver that transfers heat to the pressurized stream via heat exchanger [73]. A separate combustion-heated exchanger in series is used to increase the temperature further. This thermodynamic cycle is predicted to provide overall efficiencies of up to $37.8 \%$. This configuration may also be ideal for using supercritical $\mathrm{CO}_{2}$, rather than air as a working fluid so that higher gas-volume ratios can be achieved to reduce compressor power consumption [74].

Unlike the coal-CSP hybrid concepts discussed previously, CSP used for air heating in a gas turbine has the potential to be the primary energy source with hybrid concepts having the potential to achieve high solar fractions, at least during peak sunlight hours of the day. However, because gas turbines require very high temperatures (typically greater than $1000{ }^{\circ} \mathrm{C}$ ) to achieve 
an adequate cycle efficiency, solar receivers must push the limits of currently available technology if they are able to effectively reach these operating temperatures. The use of natural gas to add additional heat to ensure adequate temperatures, therefore, can be an effective hybridization concept as it maximizes the benefit of solar heat while using the combustible fuel to ensure a high cycle efficiency.

\subsection{Steam Injection Gas Turbines with Solar}

Another way to increase the power output from a gas turbine is by directly injecting steam into the combustor. Using this technology, known as a steam injection gas turbine (STIG), the gas turbine's heat input can be supplemented with steam, which typically would be generated by heat exchange with the turbine's flue gas in an HRSG. Hybridization with solar thermal energy involves supplementing or replacing the steam with steam generated by concentrated solar energy (see Figure 8). STIG technology is advantageous to hybridize with concentrated solar heat because it offers a lower temperature option for solar thermal heat, as the supplemental steam does not have to be injected at gas combustion temperatures, but can rather be injected near the steam's saturation temperature, which is on the order of $200-300{ }^{\circ} \mathrm{C}$, depending on the compression ratio of the gas turbine [75]. STIG technology can therefore use linear concentrators, such as parabolic trough or linear Fresnel [76], which tend to be simpler, less expensive, and more commercially proven than point concentrators (dish or central receiver). One disadvantage of this technology is that the solar share is limited to well below $100 \%$, as the power cycle relies on the combustion of a fuel to heat the gas.

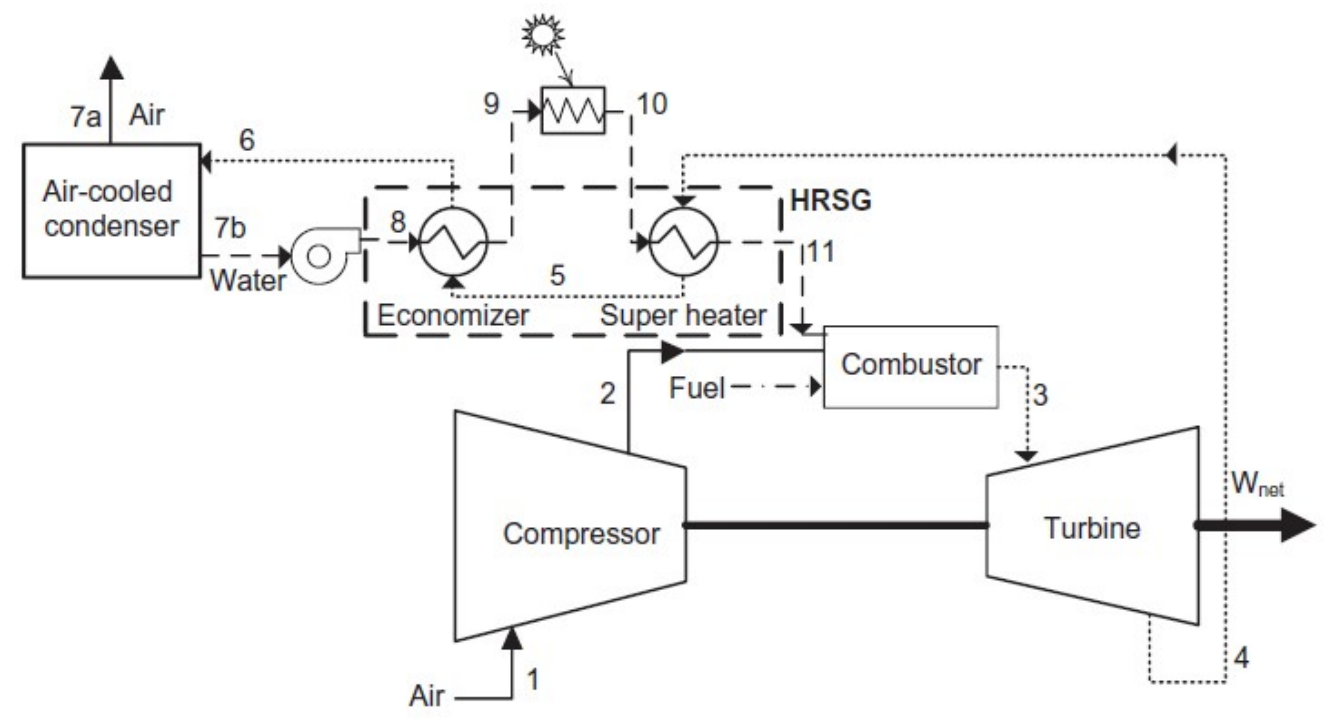

Figure 8: Layout of the solar STIG cycle. Available from [75].

Livshits and Kribus performed thermodynamic simulations of the STIG cycle at varying steam-to-air ratios, gas turbine pressure ratios, and turbine inlet temperatures to determine the total cycle efficiency and solar fraction in each scenario. Their results show that the overall conversion efficiency peaks at a steam-to-air ratio of 0.14-0.25 in each scenario with a maximum efficiency of $54.1 \%$. In their study, they demonstrated that high solar fractions require a high steam-to-air ratio, as the solar heat can only be delivered to the cycle in the steam. The 
incremental efficiency of the solar heat decreased approximately linearly with increasing solar fraction [75]. Selwynraj et al. conducted several studies to evaluate solar STIG, specifically for locations in India. Their results showed increasing exergetic efficiency with increasing steamtoair ratio, with peak performance around 54\% [77], with a separate economic analysis showing an LCOE of the solar component of energy ranging from $\$ 0.29-0.4 / \mathrm{kWh}$ (USD) [78]. A later study considered both constant and variable power modes of operation and found that the annual solar share could be as high as $41.7 \%$, depending on the location and plant design. This study showed improved economic results with the solar LCOE of $\$ 0.11-0.27 / \mathrm{kWh}[79,80]$. Polonsky et al. used a similar configuration to determine the annual performance of the solar hybrid STIG cycle, finding a higher annual solar share of 33\% if the cycle is operated in variable power mode compared to $31 \%$ in constant power mode [81]. Polonsky and Kribus conducted a simulationbased study highlighting the benefits of using thermal energy storage to enhance the solar share of the solar hybrid STIG cycle. Their design, which used PCM-based storage, showed solar shares of over 35\% annually. They also demonstrated that adding four hours of storage increases the plant's capacity factor by $50 \%$ [76]. An alternative STIG configuration uses solar thermal heat to power a methane steam reforming reaction to produce an upgraded stream of syngas (with $\mathrm{H}_{2}$ and $\mathrm{CO}$ as the desired products). The syngas stream, however, still contains unreacted steam which is then introduced into the gas turbine (with added methane), qualifying as a STIG cycle $[82,83]$. This configuration is shown in Figure 11 and is discussed further in the Solar Methane Steam Reforming section.

These studies show that solar fractions of up to $40 \%$ annually may be achievable, although that has yet to be demonstrated commercially. One of the key limitations of solar STIG is that the solar share will be limited, as this particular configuration requires combustion of a fuel, with the solar supplied heat augmenting the process. However, because the solar heat is used to augment existing steam generation and injection technologies, retrofitting a plant with solar-generated steam would require minimal modifications to the power block itself. Because combined cycle power plants are a more efficient use of gas turbine technology than simple cycle plants, perhaps the solar STIG concept could be effectively used in conjunction with solar steam turbines in a combined cycle configuration for maximum benefit.

\subsection{Solar Steam Turbines}

As the most prevalent CSP technology to date is parabolic trough, the use of steam turbines in a hybrid system is more common in the literature. Typically, these plants are built with stand-alone operation in mind, but would generally require a fuel source as a backup. However, the idea of designing and operating the plants in hybrid mode is becoming more prevalent.

Niknia and Yaghoubi investigated hybridizing an existing pilot-scale parabolic trough plant using a fossil fuel (natural gas or coal-fired auxiliary boiler) while also expanding the solar capacity with a new collector field. Dynamic simulations over the course of a year showed a maximum solar fraction of about $63 \%$ in June, which decreases to about $18 \%$ in January [84]. Peterseim and Veeraragavan explored a hybrid operation using a molten salt-based central receiver configuration to heat steam at 280 bar to $545^{\circ} \mathrm{C}$ and natural gas to boost the temperature 
to $620^{\circ} \mathrm{C}$. This was compared to a next-generation molten salt stand-alone system to heat the steam to $620{ }^{\circ} \mathrm{C}$ in a single step. The results showed a slight improvement in net efficiency of $0.3 \%$, but an identical LCOE. The main factor in this study was not hybridization, but rather the benefits of going to a supercritical steam cycle, as compared to a sub-critical steam cycle [85]. Gobereit et al. proposed using a power tower with a falling particle receiver to heat up ceramic particles. These particles are then used in a heat exchanger to generate steam for Rankine cycle power generation. A back-up heater (presumably natural gas) is used to ensure reliable operation [86]. Mokheimer et al. proposed designs using parabolic trough and linear Fresnel collectors to produce steam in parallel with an HRSG at the back end of a gas turbine system (shown in Figure 9). The steam production was intended for cogeneration, but was produced at conditions suitable for combined cycle operation. Their results show high overall efficiencies near $85 \%$ (overall cogeneration efficiency) [71].

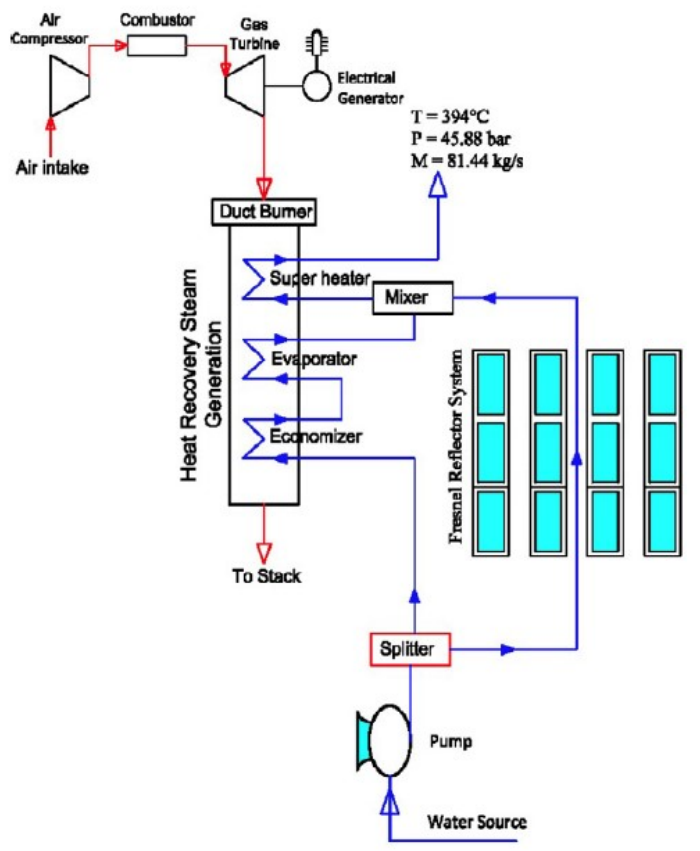

Figure 9: A cogeneration system using supplemental heat supplied by a linear Fresnel solar collection system [71].

Studies by Powell and Edgar highlighted the value of TES for increasing the solar share of a parabolic trough with natural gas plant. Their research showed that the solar share can be increased from $47.6 \%$ to $70.1 \%$ by adding 8 hours of storage $[87,88]$. A follow on study using dynamic optimization to minimize the fuel usage while providing a constant thermal load showed that by allowing flexible hybrid operation, where the portion of the load provided by natural gas can fluctuate to accommodate optimal plant performance, the solar heat collected in a 24-hour period increases by $9 \%$ on a sunny day and $49.5 \%$ on an intermittently cloudy day $[89,90]$. The major conclusion of this work was that hybrid operation with a combustible fuel adds additional flexibility to the system, which can allow the solar portion of the plant to operate at its most efficient conditions. The combination of TES with hybridization changes the 
optimization problem so that the plant can use additional degrees of freedom to achieve an optimal solution over time, rather than for a single instance [91,92].

Steam cycle technology using solar heat is most similar to the prevalent technology for stand-alone CSP plants, but in hybrid configurations, may not be the most effective use of the combustible fuel with which CSP is hybridized, as Rankine cycle power generation is generally less efficient than combined cycle. For that reason, the integrated solar combined cycle has become an increasingly popular idea in research and development.

\subsection{Integrated Solar Combined Cycle}

Integrated solar combined cycle (ISCC) plants represent a concept that has been around since the 1990s and an effective way to take advantage of the efficient combined cycle technology with the benefits of carbon-free solar power. Combined cycle power plants use gas turbine technology to power an open Brayton cycle with the waste heat recovered in an HRSG to power a steam cycle. The combined efficiency of these two power cycles is generally well over $50 \%$ and it has become a technology of choice for new power plants because of its low cost, efficiency, and relatively low emissions due to using a low-carbon fuel (natural gas). ISCC plants seek to improve this technology by integrating solar heat into the bottoming steam cycle. This configuration has the benefit of combining proven and efficient fossil fuel technology with the well-developed linear solar concentrator systems. Behar et al. gave a thorough review of ISCC in [93] and Okoroigwe and Madhlopa reviewed power-tower-specific ISCCs [94].

The ISCC configuration reduces costs of solar thermal power by $35-40 \%$ compared to stand-alone CSP technology [95] and can provide a significant solar fraction [96]. Manente et al. explored several configurations for ISCC with collector technologies including parabolic trough, linear Fresnel, and central receiver (power tower). The study explored six different configurations with both direct steam generation in the field and steam generation via heat exchange with a secondary heat transfer fluid (Therminol VP1 and molten salt), as well as multiple heat injection points into the steam generation operation. Their results determined that the most exergetically efficient configuration was parabolic trough using Therminol VP1 with an efficiency of $61.7 \%$. The other designs, however, were not far behind with the least efficient (linear Fresnel with direct steam generation) achieving an exergetic efficiency of $58.7 \%$. The linear Fresnel technology proved to have the lowest build costs, coming in at $\$ 1204 / \mathrm{kWe}$ [97]. Solar parabolic trough technology for steam generation may be done with minimal equipment modifications to conventional natural gas combined cycle technology [98]. Direct steam generation via linear concentrating technology has proven to have much potential to make a significant contribution to the energy needs of solar-rich areas [99].

The HYSOL plant design (shown in Figure 10) uses a molten salt-based power tower system with a two tank thermal energy storage system to deliver heat to a steam cycle. The design also uses a gas turbine's effluent stream as an additional heat source for the molten salt loop [100,101]. The intent of the plant is to use a bio-derived gas for combustion in the gas stream so that the plant can approach $100 \%$ renewable energy utilization [102]. 


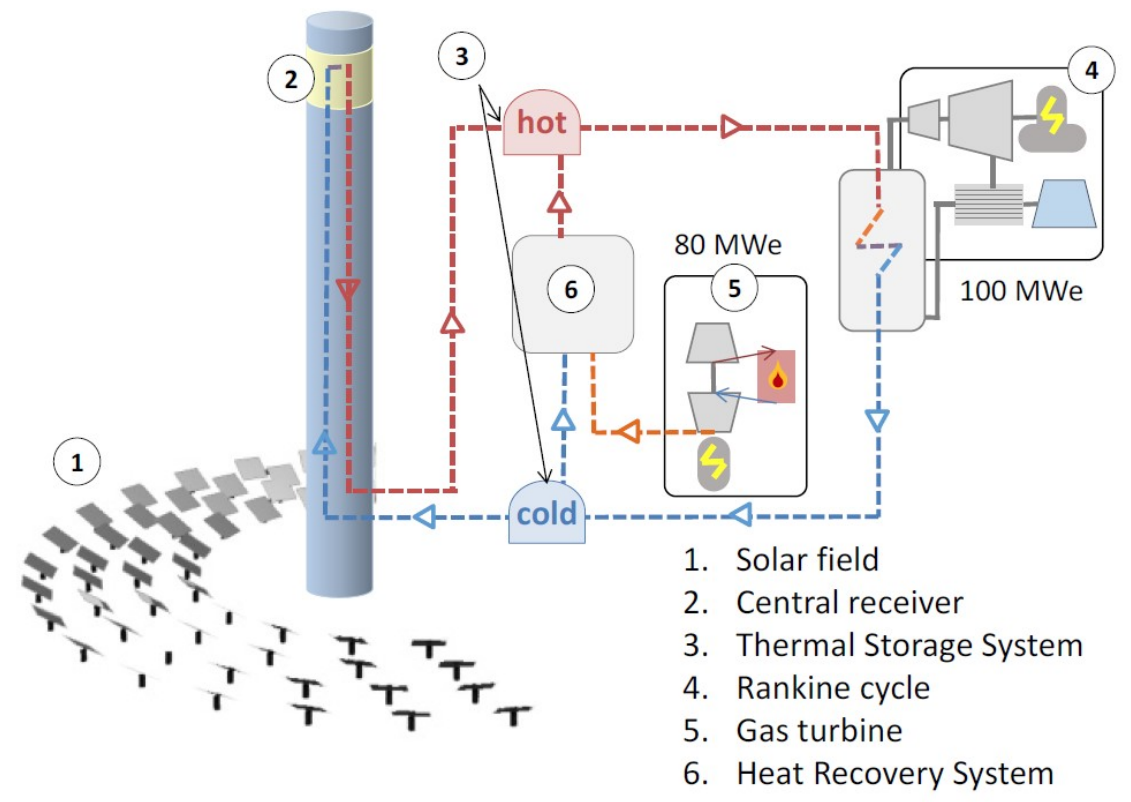

Figure 10: Graphical representation of the HYSOL plant [100].

\subsection{Solar Methane Steam Reforming}

Solar methane steam reforming (MSR) uses an endothermic chemical reaction to convert methane and steam to syngas (carbon monoxide and natural gas), which has an approximately $27 \%$ higher heating value than natural gas [103]. The reaction stores thermochemical energy and can make a good heat sink for a solar thermal process.

$$
\mathrm{CH}_{4}+\mathrm{H}_{2} \mathrm{O}_{(\mathrm{g})}+\text { heat } \rightleftharpoons \mathrm{CO}+\mathrm{H}_{2}
$$

When combined with power generation, the solar heat can be used to upgrade the fuel source and represents another potentially useful way to hybridize solar heat with natural gas. The syngas can be used to produce useful chemicals, such as methanol, or can serve on the front end of a conventional natural gas combined cycle [104].

Bianchini et al. proposed a natural gas / CSP hybrid where a parabolic trough collector field is used to provide heat for the MSR reaction to produce syngas. This solar-upgraded gas stream is then combusted in a gas turbine (see Figure 11 for a simplified process schematic, available from [82]). One of the key design and operational concerns with this configuration is the reaction temperature of the MSR reactor, which has a dramatic impact on the MSR reactor efficiency. Temperatures in excess of $600{ }^{\circ} \mathrm{C}$ are needed for the reaction to proceed at an appreciable rate (with a conversion of approximately $40 \%$ predicted at this temperature) [83]. De Falco et al. proposed an indirectly heated solar MSR reactor that uses a proven molten salt technology (also heated by parabolic trough). The solar heat is collected at $550{ }^{\circ} \mathrm{C}$ with an MSR reaction temperature of $500{ }^{\circ} \mathrm{C}$, which results in methane conversion below $11 \%$ [105]. The higher temperatures required for high conversion may justify the exploration of higher temperature solar collection technologies as they become more commercially viable. For central receiver designs, von Storch et al. explored various types of solar air receivers for indirectly 
heating an MSR reactor. Their proposed design would heat air up to $950{ }^{\circ} \mathrm{C}$ and achieve MSR temperatures of up to $935^{\circ} \mathrm{C}$, where a higher reaction conversion would be achieved [106].

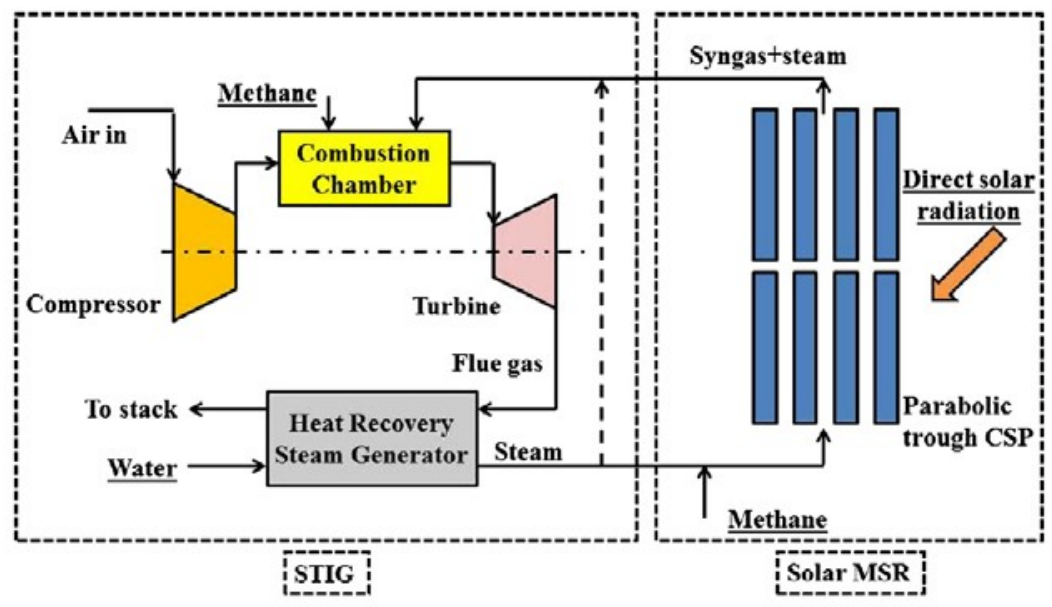

Figure 11: Solar methane steam reforming with gas turbine configuration for power production [82].

\subsection{Summary of solar/natural gas hybrids}

A summary of various configurations of solar/natural gas hybrid systems from the literature is given in Table 2. This table does not include all studies, but only those where most of the pertinent summary information is readily available.

Natural gas has a much lower carbon-to-hydrogen ratio than other fossil fuels. It is also quite abundant in North America due to recent advances in hydraulic fracturing technology, which has caused its price to fall to very low levels in recent years. Natural gas also has a high energy density and is easily transportable via pipeline. For these reasons, natural gas power production is becoming quite popular for newly constructed plants. Perhaps the most promising hybridization opportunities for CSP, therefore, are with natural gas. As effective high temperature TES technologies are developed, solar/natural gas plants could perhaps be constructed in such a way as to transition from relying mostly on natural gas to relying mostly on solar thermal energy with the gradual expansion of the solar field and storage system. This strategy could result in reasonably economic hybrid systems with the flexibility to eventually become very near carbon free, while taking advantage in the near-term of the obvious benefit of dispatchability that natural gas would provide.

Table 2: A summary of CSP-natural gas hybrid systems

\begin{tabular}{|l|l|l|l|l|l|}
\hline Configuration & $\begin{array}{l}\text { Solar } \\
\text { Collection } \\
\text { Temp. }\end{array}$ & $\begin{array}{l}\text { Collector } \\
\text { Type }\end{array}$ & $\begin{array}{l}\text { Solar heat } \\
\text { collection } \\
\text { fluid }\end{array}$ & $\begin{array}{l}\text { Solar } \\
\text { Fraction }\end{array}$ & $\begin{array}{l}\text { Solar- } \\
\text { toelectricity } \\
\text { efficiency }\end{array}$ \\
\hline Air Heating for Gas Turbine & & $\begin{array}{l}\text { Central } \\
\text { receiver }\end{array}$ & Air & $\begin{array}{l}74.2 \% \\
(31.5 \% \\
\text { annual })\end{array}$ & $\begin{array}{l}(\sim 85 \% \\
\text { cogen. })\end{array}$ \\
\hline $\begin{array}{l}\text { Power tower pre-heats air at front } \\
\text { end of GT with HRSG for } \\
\text { cogeneration [71] }\end{array}$ & $\sim 1000^{\circ} \mathrm{C}$ & & & - \\
\hline
\end{tabular}




\begin{tabular}{|c|c|c|c|c|c|}
\hline $\begin{array}{l}\text { Multiple dish and MGTs in parallel } \\
\text { combine outlet air streams to HRSG } \\
\text { for steam cycle [62] }\end{array}$ & $900^{\circ} \mathrm{C}$ & $\begin{array}{l}\text { Parabolic } \\
\text { dish }\end{array}$ & Air & $\begin{array}{l}66.4 \% \\
(\max ) \\
32.0 \% \\
\text { (annual) }\end{array}$ & $\begin{array}{l}- \\
(38.2 \% \\
\text { power } \\
\text { block })\end{array}$ \\
\hline $\begin{array}{l}\text { Parabolic dish with micro gas } \\
\text { turbine in simple-cycle mode [61] }\end{array}$ & $900^{\circ} \mathrm{C}$ & $\begin{array}{l}\text { Parabolic } \\
\text { dish }\end{array}$ & Air & $\begin{array}{l}52.590 .7 \% \\
\text { (annual) }\end{array}$ & $\begin{array}{l}16.818 .4 \% \\
\text { (annual) }\end{array}$ \\
\hline $\begin{array}{l}\text { Dish used to directly heat air for } \\
\text { recuperated gas turbine with } \\
\text { pressurized receiver [63] }\end{array}$ & $900^{\circ} \mathrm{C}$ & $\begin{array}{l}\text { Parabolic } \\
\text { dish }\end{array}$ & Air & $68.7 \%$ & $\begin{array}{l}- \\
(29.1 \% \\
\text { overall })\end{array}$ \\
\hline $\begin{array}{l}\text { Dish used to indirectly heat air for } \\
\text { recuperated gas turbine with } \\
\text { atmospheric receiver [63] }\end{array}$ & $780^{\circ} \mathrm{C}$ & $\begin{array}{l}\text { Parabolic } \\
\text { dish }\end{array}$ & Air & $\begin{array}{l}99.5 \%(\text { at } \\
\text { peak) }\end{array}$ & $\begin{array}{l} \\
(23.4 \% \\
\text { overall })\end{array}$ \\
\hline $\begin{array}{l}\text { Solar and combustion heat used in } \\
\text { series to heat closed Brayton cycle } \\
\text { via HX [73] }\end{array}$ & $800{ }^{\circ} \mathrm{C}+$ & $\begin{array}{l}\text { Central } \\
\text { receiver }\end{array}$ & Air & $\sim 37 \%$ & $\begin{array}{l}- \\
(37.8 \% \\
\text { overall })\end{array}$ \\
\hline \multicolumn{6}{|c|}{ Steam Injected Gas Turbine (STIG) } \\
\hline $\begin{array}{l}\text { Solar-aided HRSG generated steam } \\
\text { for injection into GT combustor [75] }\end{array}$ & $238.1^{\circ} \mathrm{C}$ & $\begin{array}{l}\text { Parabolic } \\
\text { trough / } \\
\text { linear } \\
\text { Fresnel }\end{array}$ & $\begin{array}{l}\text { Direct } \\
\text { steam } \\
\text { generation }\end{array}$ & $\begin{array}{l}48.9 \% \\
(\max )\end{array}$ & $15-24 \%$ \\
\hline $\begin{array}{l}\text { Solar-aided HRSG generated steam } \\
\text { for injection into GT combustor } \\
\text { [81] }\end{array}$ & $\sim 200^{\circ} \mathrm{C}$ & $\begin{array}{l}\text { Parabolic } \\
\text { trough }\end{array}$ & $\begin{array}{l}\text { Direct } \\
\text { steam } \\
\text { generation }\end{array}$ & $31-33 \%$ & $\begin{array}{l}22-26 \% \\
\text { (annual) }\end{array}$ \\
\hline $\begin{array}{l}\text { Solar-aided HRSG generated steam } \\
\text { (with latent TES) for injection into } \\
\text { GT combustor [76] }\end{array}$ & $\begin{array}{l}200-280 \\
{ }^{\circ} \mathrm{C}\end{array}$ & $\begin{array}{l}\text { Parabolic } \\
\text { trough }\end{array}$ & $\begin{array}{l}\text { Direct } \\
\text { steam } \\
\text { generation }\end{array}$ & $\begin{array}{l}35.2 \% \\
\text { (annual) }\end{array}$ & $\begin{array}{l}20.1 \% \\
\text { (annual) }\end{array}$ \\
\hline $\begin{array}{l}\text { Solar-aided HRSG generated steam } \\
\text { for injection into GT combustor } \\
[79])\end{array}$ & $202.2^{\circ} \mathrm{C}$ & $\begin{array}{l}\text { Parabolic } \\
\text { trough }\end{array}$ & $\begin{array}{l}\text { Direct } \\
\text { steam } \\
\text { generation }\end{array}$ & $\begin{array}{l}9.341 .7 \% \\
\text { (annual) }\end{array}$ & $\begin{array}{l}11.217 .1 \% \\
\text { (annual) }\end{array}$ \\
\hline \multicolumn{6}{|c|}{ Integrated Solar Combined Cycle (ISCC) } \\
\hline $\begin{array}{l}\text { PTC with DSG supplements HRSG } \\
\text { for cogen [71]. }\end{array}$ & - & $\begin{array}{l}\text { Parabolic } \\
\text { trough }\end{array}$ & $\begin{array}{l}\text { Direct } \\
\text { steam } \\
\text { generation }\end{array}$ & $\begin{array}{l}69.9 \% \\
(24.7 \% \\
\text { annual) }\end{array}$ & $\begin{array}{l}- \\
(\sim 86 \% \\
\operatorname{cogen})\end{array}$ \\
\hline $\begin{array}{l}\text { Linear Fresnel collector with DSG } \\
\text { supplements HRSG for cogen [71]. }\end{array}$ & - & $\begin{array}{l}\text { Linear } \\
\text { Fresnel }\end{array}$ & $\begin{array}{l}\text { Direct } \\
\text { steam } \\
\text { generation }\end{array}$ & $\begin{array}{l}70.7 \% \\
(23.9 \% \\
\text { (annual) }\end{array}$ & $\begin{array}{l}- \\
(82 \% \\
\text { cogen }) \\
\end{array}$ \\
\hline $\begin{array}{l}\text { HYSOL molten salt power tower } \\
\text { provides steam for Rankine. GT } \\
\text { effluent gas also used for molten } \\
\text { salt heating [100,107] }\end{array}$ & $550^{\circ} \mathrm{C}$ & $\begin{array}{l}\text { Central } \\
\text { receiver }\end{array}$ & $\begin{array}{l}\text { Molten } \\
\text { salt }\end{array}$ & $45 \%$ & $\begin{array}{l}- \\
(52 \% \text { gas- } \\
\text { toelectric })\end{array}$ \\
\hline $\begin{array}{l}\text { Aux. boiler produces saturated steam } \\
\text { in parallel with solar loop. Solar } \\
\text { used for superheating [84] }\end{array}$ & $313^{\circ} \mathrm{C}$ & $\begin{array}{l}\text { Parabolic } \\
\text { trough }\end{array}$ & $\begin{array}{l}\text { Therminol } \\
\text { VP1 and } \\
\text { Behran Oil }\end{array}$ & $\begin{array}{l}\sim 63 \% \text { in } \\
\text { June, } \\
\sim 18 \% \text { in } \\
\text { Jan. }\end{array}$ & $\begin{array}{l}- \\
(20-42 \% \\
\text { overall })\end{array}$ \\
\hline
\end{tabular}




\begin{tabular}{|c|c|c|c|c|c|}
\hline $\begin{array}{l}\text { Power tower/molten salt with gas to } \\
\text { reach supercritical steam conditions } \\
\text { [85] }\end{array}$ & $700^{\circ} \mathrm{C}$ & $\begin{array}{l}\text { Central } \\
\text { receiver }\end{array}$ & $\begin{array}{l}\text { High temp } \\
\text { molten } \\
\text { salt }\end{array}$ & - & $\begin{array}{l}- \\
(43.2 \% \\
\text { overall })\end{array}$ \\
\hline $\begin{array}{l}\text { Parabolic trough with oil in ISCC } \\
\text { [97] }\end{array}$ & $393^{\circ} \mathrm{C}$ & $\begin{array}{l}\text { Parabolic } \\
\text { trough }\end{array}$ & $\begin{array}{l}\text { Therminol } \\
\text { VP1 }\end{array}$ & $12.8 \%$ & $29.7 \%$ \\
\hline $\begin{array}{l}\text { Parabolic trough with molten salt in } \\
\text { ISCC [97] }\end{array}$ & $454{ }^{\circ} \mathrm{C}+$ & $\begin{array}{l}\text { Parabolic } \\
\text { trough }\end{array}$ & $\begin{array}{l}\text { Molten } \\
\text { salt }\end{array}$ & $12.8 \%$ & $29.2 \%$ \\
\hline $\begin{array}{l}\text { Power tower with molten salt in } \\
\text { ISCC [97] }\end{array}$ & $565^{\circ} \mathrm{C}$ & $\begin{array}{l}\text { Central } \\
\text { receiver }\end{array}$ & $\begin{array}{l}\text { Molten } \\
\text { salt }\end{array}$ & $12.8 \%$ & $27.5 \%$ \\
\hline $\begin{array}{l}\text { Linear Fresnel with DSG in ISCC } \\
\text { [97] }\end{array}$ & $454^{\circ} \mathrm{C}$ & $\begin{array}{l}\text { Linear } \\
\text { Fresnel }\end{array}$ & $\begin{array}{l}\text { Direct } \\
\text { steam } \\
\text { generation }\end{array}$ & $12.8 \%$ & $26.8 \%$ \\
\hline \multicolumn{6}{|l|}{ Methane Steam Reforming } \\
\hline $\begin{array}{l}\text { MSR reaction occurs in parabolic } \\
\text { trough. Syngas used for gas turbine } \\
\text { power generation [83] }\end{array}$ & $600{ }^{\circ} \mathrm{C}$ & $\begin{array}{l}\text { Parabolic } \\
\text { Trough }\end{array}$ & $\begin{array}{l}\text { Steam } \\
\text { reforming } \\
\text { reactants/ } \\
\text { products }\end{array}$ & - & - \\
\hline
\end{tabular}

\section{Hybridization with Biofuels}

As hybridization of solar thermal energy with fossil fuels has demonstrated good synergies, hybridization with bio-fuels exhibits many of the same benefits (i.e., renewable energy with combustible fuel to improve flexibility and reliability), but has the potential to provide $100 \%$ renewable energy [108]. A life cycle assessment by Miguel and Corona showed that most of the environmental damage caused by a hybrid solar thermal/fossil fuel plant is caused by burning the fuel, rather than in plant construction. Most of the negative impact is removed, however, if the fossil fuel is replaced with biogas or biomethane as the hybrid fuel source [109]. CSP can be combined with a number of different biomass sources including: forestry residues, bagasse, stubble, wood waste, and refuse-derived fuels [110]. CSP can also be used as a supplemental heat source in the production of hydrogen $[111,112]$ or liquid biofuels for transportation $[113,114]$. The production of syngas or liquid transportation fuels using solar thermal energy as an input source is actually a storage mechanism, which has many benefits including the ability to store energy long-term as high temperatures do not have to be maintained [115]. Because biofuels are another combustible fuel, the solar/biofuel hybrids have similar configurations as solar/natural gas hybrids.

\subsection{Solar Steam Generation}

Peterseim et al. explored a number of CSP/biomass hybrid technologies to determine which combinations of technologies were best economically and environmentally. In these configurations, the CSP technology is used to generate steam (at identical conditions) in parallel with a biomass boiler system. According to this study, the best combination in terms of efficiency and environmental benefits is a power tower system using direct steam generation combined with a biomass gasification system, which shows a peak net efficiency of $33.2 \%$. The 
best system in terms of economics, however, is a linear Fresnel CSP system with direct steam generation in conjunction with a fluidized bed biomass boiler. This combination still has a high efficiency (32.5\%) and has an investment cost that is $69 \%$ lower than a stand-alone CSP system [116]. Biomass combustion can also be used to superheat steam produced from a parabolic trough plant to increase steam temperatures and the power block efficiency. One study showed that doing this can increase the solar-to-electric efficiency by up to $10.5 \%$, while decreasing the investment cost by up to $23.5 \%$ [117]. Coelho et al. studied the use of a power-tower-based air heater that is used in an HRSG to generate steam. Biogas or syngas is then used in HRSG duct burners to supplement the heat. The study explored multiple sources of biofuel including wood gasification, refuse-derived fuel pellets, biogas from a wastewater anaerobic digester, and biogas from a landfill. They found that the most economical option was the wastewater anaerobic digester with an internal rate of return (IRR) of $11 \%$ [118].

Hybridization of CSP with biogas from agro-livestock and municipal waste has demonstrated some economic potential [119], with some configurations using dish-based concentrated PV technology with biogas [120]. Peterseim et al. conducted a techno-economic assessment of a solar/biomass fired system where a power tower with molten salt (and three hours of storage) produced steam in parallel with a biomass-fired boiler. Their results indicated an investment cost $43 \%$ lower than a stand-alone CSP plant [121]. Biofuel and solar thermal hybrids in district energy systems can make effective utilization of low grade heat using an organic Rankine cycle [122], which may include waste heat recovery used for district heating [123]. The intent of the HYSOL plant discussed previously is also to run on bio-derived natural gas $[100,101,107]$.

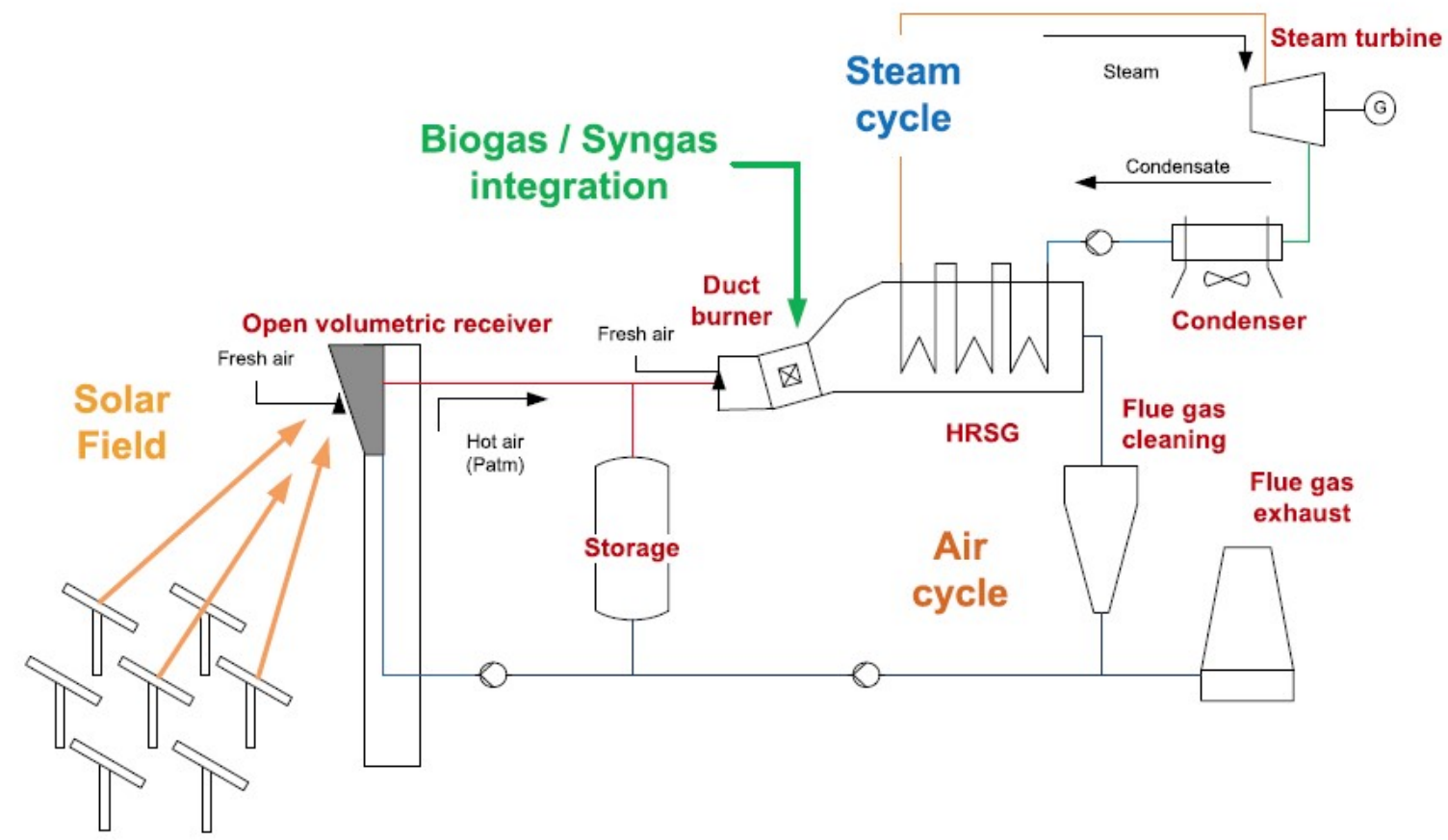

Figure 12: The use of a solar power tower to pre-heat air for a HRSG in a biogas/syngas-based steam cycle power plant [118]. 


\subsection{Solar Gasification of Biofuels}

As with coal gasification, solar-aided gasification of biomass has become an increasingly popular research topic. Gasification of biomass via high temperature solar thermal processes can achieve theoretical solar-to-chemical efficiencies of up to 50\% [124]. Gasification of biomass requires a heat source. Typically, the heat source is partial combustion of the biomass itself. Using CSP as an alternative heat source, the biomass feedstock can be preserved so that more syngas is produced $[125,126]$. Syngas can also be used to provide additional heat to a solarheated HRSG to produce steam for a Rankine cycle power plant [118]. Solar heat can also be used to generate low temperature steam for biomass gasification [127].

Gupta et al. proposed a catalytic combustion system that uses syngas (resulting from biomass gasification) as a supplemental fuel to help regulate CSP plant output during intermittent solar availability. According to their experimental study, this type of combustion system is ideal to pair with CSP processes because it exhibits stable operation, a high turn-down ratio (up to 1.67), and quick start up [128]. Energy and exergy analysis of a similar system shows that thermal efficiencies of up to $36.5 \%$ can be achieved [129]. Solar-aided biomass gasification can also be hybridized with coal as a third energy source with the syngas used to make liquid fuels with the tail gas used to produce electricity [130]. One of the key issues of biomass gasification using a directly heated solar reactor is effective heat distribution throughout the reactor to ensure efficient gasification. The development of such systems requires careful design, simulation, and testing [131,132].

Tanaka et al. explored a combination of the IGCC and ISCC concepts. Their design uses biomass gasification to produce syngas that is combusted in a gas turbine. The waste heat is then recovered in an HRSG, which is also used to supplement solar-generated steam from a molten salt power tower plant. Efficiencies (solar-to-electric) of over $20 \%$ are achieved in this configuration and the power output of the plant is increased [133]. A similar study shows that the marginal efficiency of biomass-to-electricity can be increased by over $6 \%$ when adding solar [134]. Liu et al. compared two possible configuration schemes for integrating high temperature solar heat (via power tower) with biomass gasification and combined cycle. The first concept used a solar-heated biomass gasifier to produce syngas, which was then used in combined cycle operation. This configuration was referred to as solar-gasification combined cycle (SGCC) and was compared to another configuration referred to as solar hybrid combined cycle (SHCC), where a power tower is used to heat air (post compression) with supplemental heat coming from syngas generated from a biomass gasifier. This thermodynamic study showed that the SGCC was more efficient both overall (29.4\% annual efficiency) and in terms of solar-to-electricity ( $18.5 \%$ annual efficiency) [135]. These concepts are shown schematically in Figure 13. 


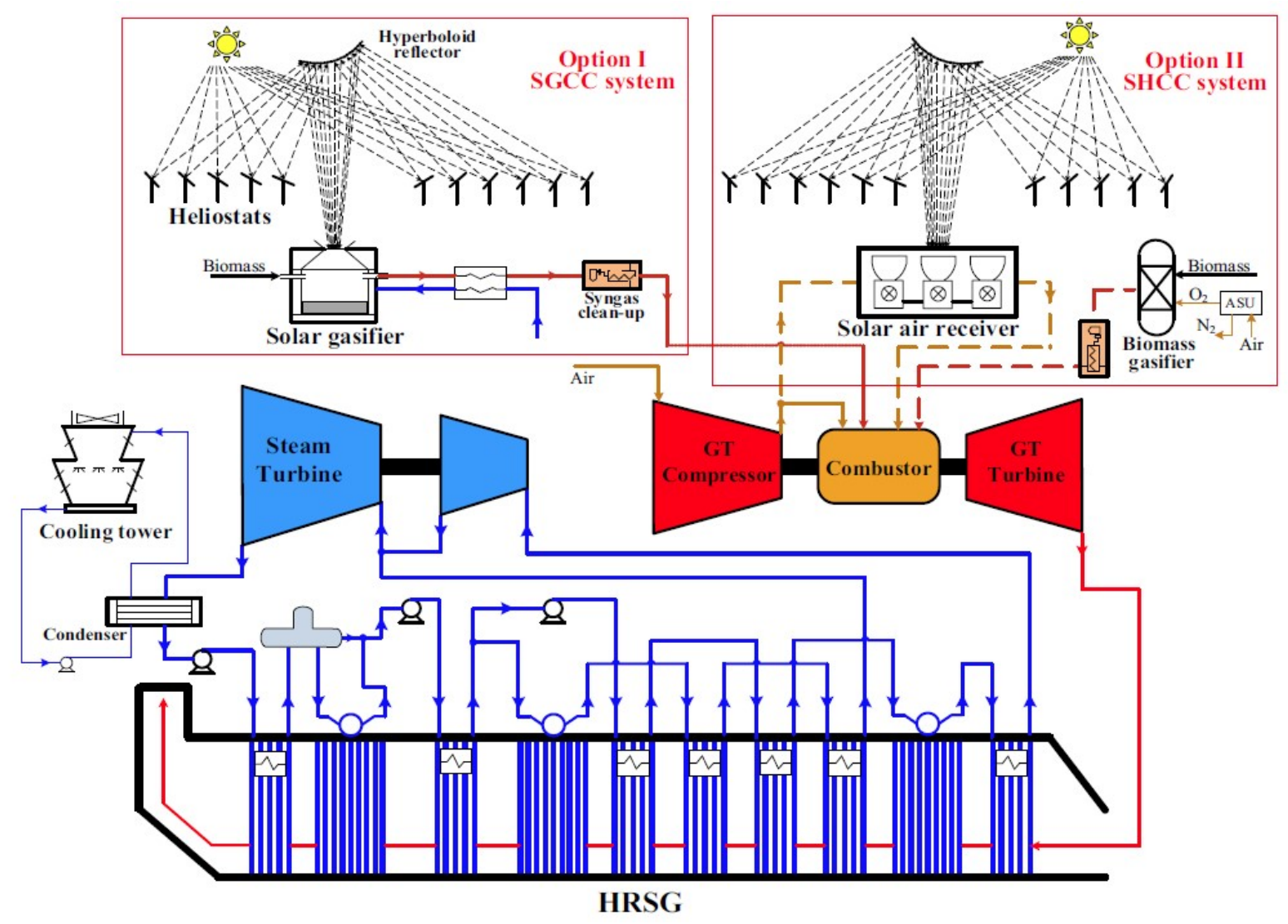

Figure 13: SGCC and SHCC concepts proposed by Liu et al. [135].

\subsection{Solar-Aided Biomass Gasification with Multi-Generation}

In addition to electricity and fuels production from biofuel/solar thermal systems, multigeneration systems, that simultaneously produce multiple useful commodities have been explored using this hybrid combination. Zhang et al. studied a solar-assisted tri-generation system that produces electricity, chilled water, and hot water and uses biomass gasification as the primary heat source. In this configuration a parabolic trough system (operating at $350{ }^{\circ} \mathrm{C}$ ) is used to produce steam for the biomass gasifier. The waste heat from the gasifier's syngas stream is used to produce domestic hot water. The syngas is then burned in an internal combustion engine to produce electricity with the waste heat from this stream recovered in an absorption chiller to make chilled water. The use of multi-generation in this configuration results in a very high overall energy efficiency of $77.4 \%$, while the electrical efficiency is $17.8 \%$ [136]. As multigeneration hybrid-source systems may have multiple combinations of technologies, optimization around the plant design can be a valuable endeavor to determine which components should be included and how that impacts the overall costs $[137,138]$.

High temperature solar-heated gasification of biomass can also be used for cogeneration of useful chemical products and electric power. Bai et al. studied a system that uses a power tower configuration to directly heat a biomass gasification reactor to $1000-1500 \mathrm{~K}$. The resulting syngas is ultimately used in the synthesis of methanol, with the un-reacted gas used in a combined cycle power plant to produce electricity. Multi-generation allows the system to achieve 
high energy efficiencies of over 56\% [139,140]. A benefit of producing stable chemical product from multi-generation systems is that this configuration would not require co-location with a heat sink (industrial or residential) to make beneficial use of the otherwise wasted thermal energy.

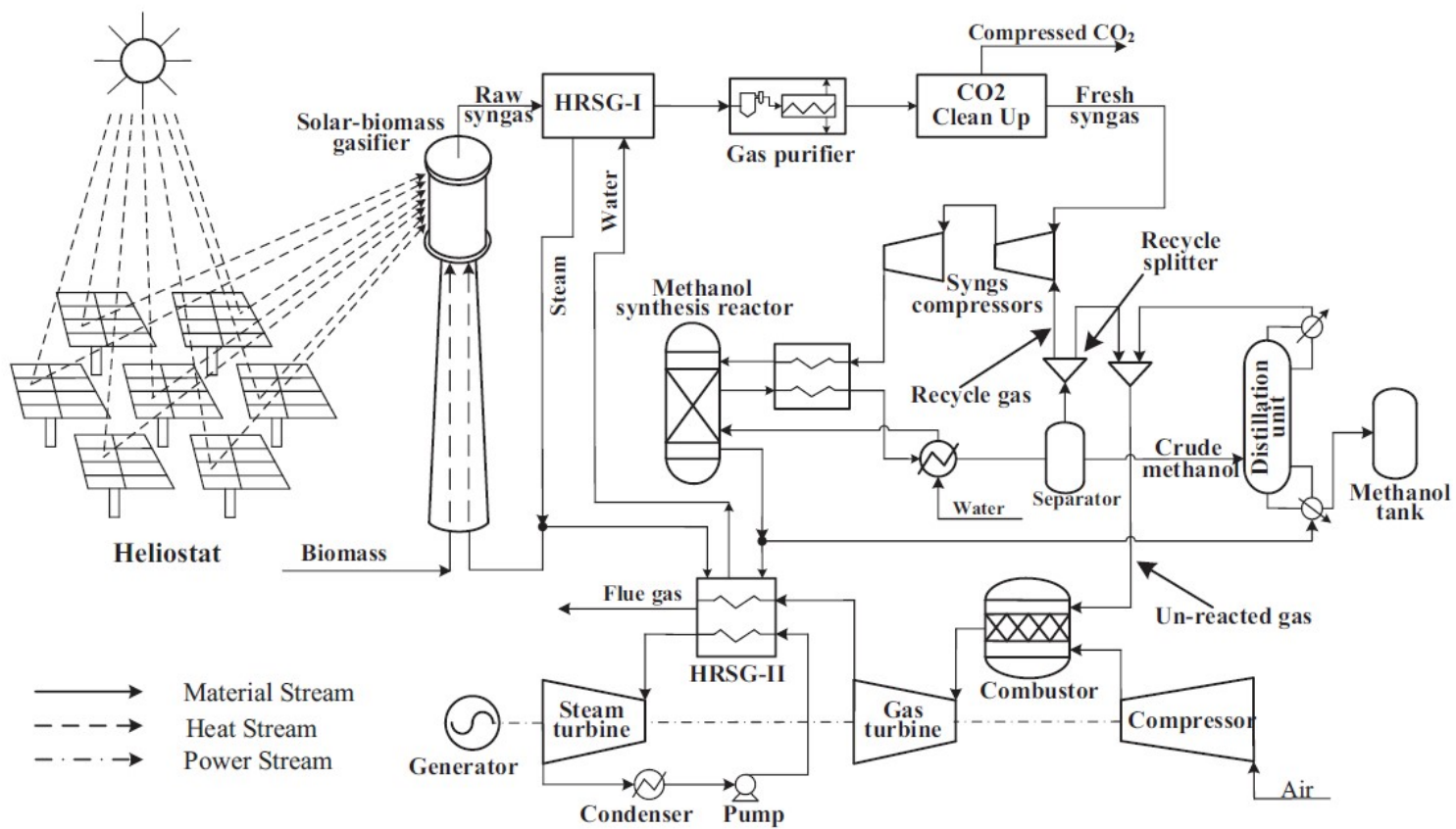

Figure 14: A schematic diagram of a multi-generation system that uses solar thermal gasification of biomass to simultaneously produce methanol and power [140].

\subsection{Summary of Solar/Biofuel Hybrids}

A summary of the performance metrics from various studies on solar/biofuel hybrid systems is given in Table 3. Solar/biofuel hybrids have many of the same benefits as solar hybrids with natural gas and coal, however, the overriding benefit is that these systems have the potential to be $100 \%$ sustainable. While still providing reliable, dispatchable power.

Table 3: A summary of CSP-biofuel hybrid systems

\begin{tabular}{|l|l|l|l|l|l|}
\hline Configuration & $\begin{array}{l}\text { Solar } \\
\text { collection } \\
\text { temp. }\end{array}$ & $\begin{array}{l}\text { Collector } \\
\text { type }\end{array}$ & $\begin{array}{l}\text { Solar } \\
\text { fraction }\end{array}$ & $\begin{array}{l}\text { Solar heat } \\
\text { collection } \\
\text { fluid }\end{array}$ & $\begin{array}{l}\text { Solar- } \\
\text { toelectricity } \\
\text { efficiency }\end{array}$ \\
\hline Solar/Biofuel Steam Generation & & & & \\
\hline $\begin{array}{l}\text { Biomass-fired boiler and } \\
\text { MoltenSalt/Power tower boiler used } \\
\text { in parallel for steam generation in } \\
\text { steam cycle [121] }\end{array}$ & $540^{\circ} \mathrm{C}$ & $\begin{array}{l}\text { Central } \\
\text { receiver }\end{array}$ & $\begin{array}{l}23.9 \% \\
(\text { annual })\end{array}$ & Molten Salt & $\begin{array}{l}- \\
(33.4 \% \\
\text { overall })\end{array}$ \\
\hline $\begin{array}{l}\text { Biomass used to superheat steam } \\
\text { after being generated by parabolic } \\
\text { trough plant [117] }\end{array}$ & $393^{\circ} \mathrm{C}$ & $\begin{array}{l}\text { Parabolic } \\
\text { trough }\end{array}$ & - & Thermal Oil & $27.5 \%$ \\
\hline $\begin{array}{l}\text { Biomass furnace and PT with } \\
\text { thermal oil used to supply heat to }\end{array}$ & $305^{\circ} \mathrm{C}$ & $\begin{array}{l}\text { Parabolic } \\
\text { trough }\end{array}$ & $9 \%$ & Thermal Oil & - \\
\hline
\end{tabular}




\begin{tabular}{|c|c|c|c|c|c|}
\hline $\begin{array}{l}\text { ORC with waste heat providing } \\
\text { district heating [123] }\end{array}$ & & & & & $\begin{array}{l}(16 \% \\
\text { overall } \\
\text { electric })\end{array}$ \\
\hline $\begin{array}{l}\text { Power tower used to pre-heat air. } \\
\text { Syngas/biogas used for HRSG } \\
\text { duct burning [118] }\end{array}$ & $700^{\circ} \mathrm{C}$ & $\begin{array}{l}\text { Central } \\
\text { receiver }\end{array}$ & $\begin{array}{l}\text { Up to } \\
50 \%\end{array}$ & Air & $11 \%$ \\
\hline \multicolumn{6}{|l|}{ Solar/Biofuel Gasification } \\
\hline $\begin{array}{l}\text { IGCC using biomass shares HRSG } \\
\text { with molten salt power tower } \\
\text { system } \\
{[133]}\end{array}$ & $565^{\circ} \mathrm{C}$ & $\begin{array}{l}\text { Central } \\
\text { receiver }\end{array}$ & - & Molten Salt & $20 \%$ \\
\hline $\begin{array}{l}\text { Power tower Solar biomass gasifier } \\
\text { makes syngas for IGCC [135]. }\end{array}$ & $877^{\circ} \mathrm{C}$ & $\begin{array}{l}\text { Central } \\
\text { receiver }\end{array}$ & $19.0 \%$ & $\begin{array}{l}\text { Gasification } \\
\text { reactants/ } \\
\text { products }\end{array}$ & $\begin{array}{l}21.3 \% \\
(18.5 \% \\
\text { annual) }\end{array}$ \\
\hline $\begin{array}{l}\text { Power tower air heater heats air for } \\
\text { combustor. Biomass gasifier in } \\
\text { parallel makes syngas. Combined } \\
\text { cycle operation [135] }\end{array}$ & $877^{\circ} \mathrm{C}$ & $\begin{array}{l}\text { Central } \\
\text { receiver }\end{array}$ & $19.0 \%$ & Air & $\begin{array}{l}17.3 \% \\
(15.1 \% \\
\text { annual) }\end{array}$ \\
\hline \multicolumn{6}{|c|}{ Solar/Biofuel Gasification with Multi-Generation } \\
\hline $\begin{array}{l}\text { PT Solar collector makes steam for } \\
\text { biomass gasification with cogen of } \\
\text { chilled water and hot water [136] }\end{array}$ & $350^{\circ} \mathrm{C}$ & $\begin{array}{l}\text { Parabolic } \\
\text { trough }\end{array}$ & $8.6 \%$ & - & $\begin{array}{l}- \\
(17.8 \% \\
\text { overall })\end{array}$ \\
\hline $\begin{array}{l}\text { Biomass gasification reactor heated } \\
\text { by power tower. Products used for } \\
\text { methanol synthesis and power } \\
\text { production via combined cycle } \\
{[140]}\end{array}$ & $\begin{array}{l}727-1227 \\
{ }^{\circ} \mathrm{C}\end{array}$ & $\begin{array}{l}\text { Central } \\
\text { receiver }\end{array}$ & - & $\begin{array}{l}\text { Gasification } \\
\text { reactants/ } \\
\text { products }\end{array}$ & $\begin{array}{l}- \\
(56.1 \% \\
\text { overall })\end{array}$ \\
\hline
\end{tabular}

\section{Hybridization with Geothermal}

Another hybrid energy source that can be coupled with solar thermal is geothermal energy. Like solar/biofuel combinations, solar/geothermal has the potential for purely renewable energy systems. Geothermal heat is somewhat dispatchable and provides some reliability for the system. However, geothermal heat tends to be of lower grade and typically requires heat exchange from the geothermal brine available in the well water to generate steam, or more commonly, to an organic working fluid, which vaporizes at lower temperatures and is more suitable for the low temperatures encountered with geothermal energy. It is not uncommon for systems to utilize low grade geothermal or low grade solar thermal heat using an organic Rankine cycle [141,142]. Another common utilization of low grade solar/geothermal heat in studies is in cogeneration systems (or multi-generation systems) where the power production plant is co-located with other heat sinks that are better suited to take advantage of this lower grade heat.

\subsection{Solar-Geothermal Electricity Production}

In a technical and economic analysis of a solar-geothermal hybrid utilizing an organic Rankine cycle for four sites (two in California and two in Italy), Astolfi et al. found LCOEs between 145 and $280 € / M W h$ (2010 currency values). One key finding of their study was a 
drastic increase in the capacity factor when hybridizing CSP with geothermal. Capacity factors increased from $99-253 \%$ for the four locations studied [143]. Ayub et al. conducted a similar study using lower temperature CSP and geothermal heat with an organic Rankine cycle, although with a low solar fraction of 7\%. Their findings showed that hybridization reduced LCOE by only $2 \%$, whereas optimization of a geothermal only plant reduced LCOE by $8 \%$ [144]. Ghasemi et al. demonstrated the use of optimization to exploit synergies of a hybridized geothermal/CSP system. Their study showed that by optimizing, an increase of up to $3.4 \%$ in second-law efficiency compared to the combined efficiency of a stand-alone solar and a stand-alone geothermal system. In this configuration, solar thermal energy is used in parallel with geothermal energy and is used to heat part of the working fluid [145]. Zhou performed a parametric study on both sub-critical and super-critical organic Rankine cycles in solar/geothermal hybrid plants. This study showed that a hybrid plant would produce $15 \%$ and $19 \%$ more power annually for a sub-critical ORC and super-critical ORC, respectively, than two stand-alone plants [146].

An alternative to low temperature organic Rankine cycles is to upgrade the geothermal fluid directly with CSP by using a solar field and steam turbine in series with the geothermal wells, as demonstrated in a study by Lentz and Almanza [147]. A parametric study conducted by Zhou et al. highlighted strong synergies between CSP and geothermal systems, reporting up to $23 \%$ reduction in LCOE when hybridizing versus stand-alone CSP [148]. This configuration may present some issues in using the geothermal brine as the working fluid, such as corrosion and limited performance [146] or scaling on process equipment due to the brine's high silica content [149]. In the case of using the geothermal brine directly in CSP, these issues must be considered and mitigated to ensure a long plant lifetime.

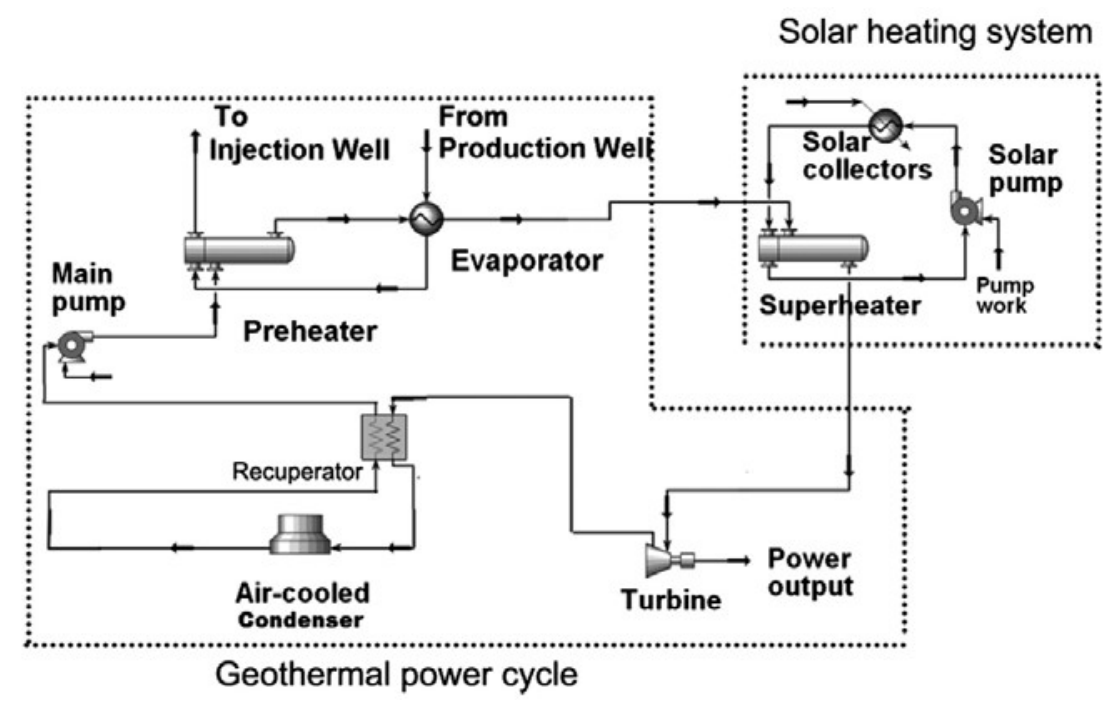

Figure 15: A solar / geothermal hybrid system using an organic Rankine cycle for power production [146].

\subsection{Solar-Geothermal Multi-Generation}

As another method for boosting the overall efficiency of solar/geothermal hybrid systems, many studies have considered these systems in the context of a district energy system, where some of the lower grade heat can be used for other purposes beyond electricity. Al-Ali and 
Dincer performed exergy and energy analysis on a multi-generational solar-geothermal hybrid system (shown in Figure 16). The system proposed in this work does not merely produce electrical energy, but utilizes co-location with industrial and building district energy networks to provide space heating, industrial heating, hot water, and cooling in addition to electric power. This proposed system utilizes geothermal heat produced at $190{ }^{\circ} \mathrm{C}$ and solar thermal heat produced at $395{ }^{\circ} \mathrm{C}$ in conjunction with multiple energy loops (including two organic Rankine cycles) to deliver multiple forms of energy. This study found that energy efficiency increases from $16.4 \%$ to $78 \%$ when going from single-generation (electricity production only) to multigeneration, as the multi-generation system takes much better advantage of low grade heat from geothermal energy [150]. This configuration could be beneficial due to the high efficiency of multi-generation, but would require co-location of a solar thermal resource, a geothermal resource, and heat sinks that can effectively utilize each energy stream. Calise et al. performed a dynamic simulation of a CSP/geothermal hybrid in a multi-generation energy system. In this case, the system not only provides electricity via a geothermal and solar thermal heat supplied organic Rankine cycle, but also heat, cooling, and fresh water via desalination by distillation to a small community. The study found electricity production costs in the range of $0.1475-0.1722$ $€ / \mathrm{kWh}$ with the added benefit of producing many other forms of valuable energy and fresh water [151]. Ezzat and Dincer reported that by considering solar/geothermal hybrids in a polygeneration district energy system, the overall efficiency increases by a factor of roughly five when compared to a geothermal power generation process by itself [152]. Ghosh and Dincer demonstrated that a polygeneration system can also have multiple sources of heat and considered a solar-geothermal-wind hybrid polygeneration system that produced multiple useful commodities [153].

Similar studies on solar/geothermal multi-generation systems use non-concentrating solar collectors in the form of flat plate $[154,155]$ or solar photovoltaic/thermal (PVT) collectors [156] to provide lower grade district energy systems. Even with non-concentrating solar collectors, however, some of these systems are still able to produce electricity for combined heat and power systems via organic Rankine cycles $[157,158]$. 


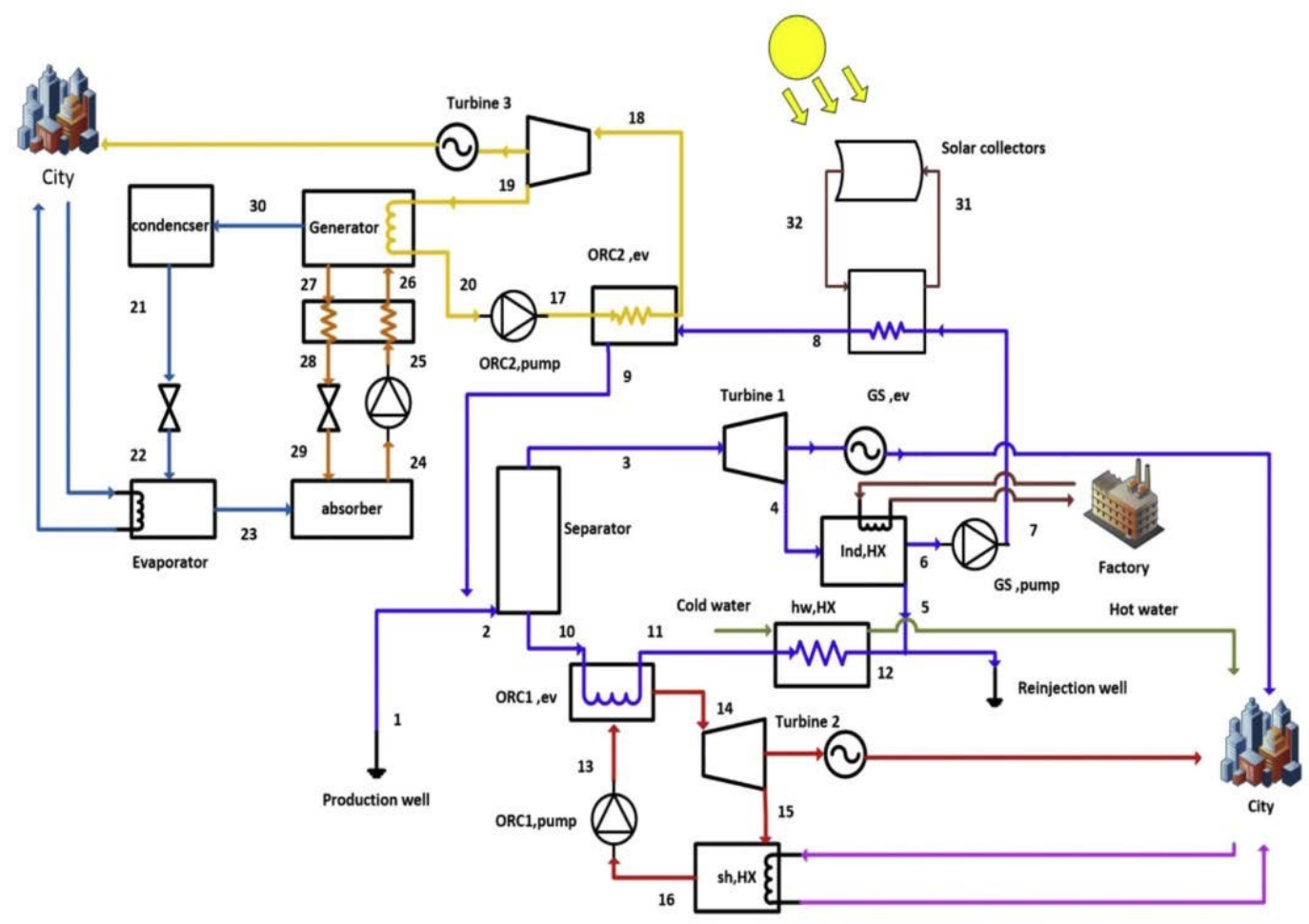

Figure 16: The multi-generation solar-geothermal hybrid system proposed by Al-Ali and Dincer [150].

\subsection{Summary of solar/geothermal hybrids}

Studies on solar/geothermal hybrid systems are summarized in Table 4. One of the key benefits of hybridizing solar and geothermal energy is that each source is carbon-free. There are also some synergies between the two energy sources. While geothermal energy can be thought of as dispatchable, it is generally low temperature (and therefore, low grade) heat. Solar thermal energy, on the other hand, can be collected at high temperatures, which can enhance the efficiency of the combined system. Absent long-term TES for the solar component (i.e., over eight hours of storage), an integrated solar/geothermal system will still have a low capacity factor. Such a system will require a way to use the lower grade geothermal heat when high temperature solar heat is not available to upgrade it. Multi-generation systems with multiple heatinjection points have been proposed. Co-locating these various heat sinks may be difficult, however, as the solar resources is generally best in isolated areas where there is an abundance of land, while the multi-generation system requires another heat sink (e.g., buildings or industrial processes) in close proximity to effectively use the heat.

Table 4: A summary of CSP-geothermal hybrid systems

\begin{tabular}{|l|l|l|l|l|l|}
\hline Configuration & $\begin{array}{l}\text { Solar } \\
\text { collection } \\
\text { temp. }\end{array}$ & $\begin{array}{l}\text { Collector } \\
\text { Type }\end{array}$ & $\begin{array}{l}\text { Solar heat } \\
\text { collection } \\
\text { fluid }\end{array}$ & $\begin{array}{l}\text { Solar } \\
\text { Fraction }\end{array}$ & $\begin{array}{l}\text { Solar- } \\
\text { toelectricity } \\
\text { efficiency }\end{array}$ \\
\hline Solar/Geothermal Electricity Production \\
\hline $\begin{array}{l}\text { Solar HX used in series after } \\
\text { geothermal HX for ORC }[143]\end{array}$ & $\begin{array}{l}170-200 \\
{ }^{\circ} \mathrm{C}\end{array}$ & $\begin{array}{l}\text { Parabolic } \\
\text { Trough }\end{array}$ & $\begin{array}{l}\text { Therminol } \\
55\end{array}$ & $\begin{array}{l}28.3- \\
50.2 \%\end{array}$ & $\begin{array}{l}8.5-9.4 \% \\
\text { (annual) }\end{array}$ \\
\hline
\end{tabular}




\begin{tabular}{|c|c|c|c|c|c|}
\hline $\begin{array}{l}\text { Geothermal brine HX used in } \\
\text { parallel with solar HX for ORC } \\
{[144]}\end{array}$ & $\begin{array}{l}170-200 \\
{ }^{\circ} \mathrm{C}\end{array}$ & $\begin{array}{l}\text { Parabolic } \\
\text { Trough }\end{array}$ & $\begin{array}{l}\text { Therminol } \\
\text { VP1 }\end{array}$ & $7 \%$ & $7.8 \%$ \\
\hline $\begin{array}{l}\text { Geothermal brine vaporizer } \\
\text { used in parallel with solar } \\
\text { vaporizer with geothermal } \\
\text { preheating for ORC [145] }\end{array}$ & $\begin{array}{l}182^{\circ} \mathrm{C} \\
(\max )\end{array}$ & $\begin{array}{l}\text { Parabolic } \\
\text { Trough }\end{array}$ & $\begin{array}{l}\text { Therminol } \\
\text { VP1 }\end{array}$ & - & $17.9 \%$ \\
\hline $\begin{array}{l}\text { Solar superheater used in series } \\
\text { with geothermal vaporizer for } \\
\text { ORC [146] }\end{array}$ & $\begin{array}{l}390^{\circ} \mathrm{C} \\
(\max )\end{array}$ & $\begin{array}{l}\text { Parabolic } \\
\text { Trough }\end{array}$ & $\begin{array}{l}\text { Therminol } \\
\text { VP1 }\end{array}$ & $\begin{array}{l}29.3- \\
70.4 \%\end{array}$ & $6.2-13.6 \%$ \\
\hline $\begin{array}{l}\text { Direct use of brine in with solar } \\
\text { and geothermal in series and in } \\
\text { parallel (two different configs) } \\
{[147]}\end{array}$ & - & $\begin{array}{l}\text { Parabolic } \\
\text { Trough }\end{array}$ & $\begin{array}{l}\text { Direct } \\
\text { steam } \\
\text { generation }\end{array}$ & - & $\begin{array}{l}- \\
(70 \% \\
\text { thermal })\end{array}$ \\
\hline $\begin{array}{l}\text { Solar superheater used in series } \\
\text { with geothermal vaporizer in } \\
\text { ORC }[148]\end{array}$ & $\begin{array}{l}390^{\circ} \mathrm{C} \\
(\max )\end{array}$ & $\begin{array}{l}\text { Parabolic } \\
\text { Trough }\end{array}$ & $\begin{array}{l}\text { Therminol } \\
\text { VP1 }\end{array}$ & $\begin{array}{l}68 \% \\
\text { (breakeven) }\end{array}$ & $\begin{array}{l}- \\
(12.36 \% \\
\text { overall } \\
\text { exergy })\end{array}$ \\
\hline \multicolumn{6}{|c|}{ Solar/Geothermal for Multi-Generation } \\
\hline $\begin{array}{l}\text { Multi-generation system with } \\
\text { solar and geothermal producing } \\
\text { power in parallel via ORC and } \\
\text { simultaneous production of } \\
\text { cooling, and heating [150] }\end{array}$ & $395^{\circ} \mathrm{C}$ & $\begin{array}{l}\text { Parabolic } \\
\text { Trough }\end{array}$ & $\begin{array}{l}\text { Therminol } \\
\text { VP1 }\end{array}$ & - & $\begin{array}{l}- \\
(22 \% \\
\text { thermal })\end{array}$ \\
\hline $\begin{array}{l}\text { Solar HX used in series with } \\
\text { geothermal HX to heat oil for } \\
\text { ORC. Cooling, heating, and } \\
\text { water also produced [151] }\end{array}$ & $\begin{array}{l}150-200 \\
{ }^{\circ} \mathrm{C}\end{array}$ & $\begin{array}{l}\text { Parabolic } \\
\text { Trough }\end{array}$ & $\begin{array}{l}\text { Dowtherm } \\
\text { A }\end{array}$ & $9.60 \%$ & $\begin{array}{l}- \\
(11.6 \% \\
\text { overall })\end{array}$ \\
\hline $\begin{array}{l}\text { Recycled solar heat from } \\
\text { thermal oil used to re-heat } \\
\text { geothermal brine; includes } \\
\text { multi-gen of water (with wind } \\
\text { power for pumping), cooling, } \\
\text { and heating [153] }\end{array}$ & $350^{\circ} \mathrm{C}$ & $\begin{array}{l}\text { Parabolic } \\
\text { Trough }\end{array}$ & - & - & $\begin{array}{l}- \\
(36.7 \% \\
\text { overall })\end{array}$ \\
\hline $\begin{array}{l}\text { Solar thermal heat used to } \\
\text { reheat geothermal brine for } \\
\text { power production; includes } \\
\text { multi-gen of drying, heating, } \\
\text { and cooling [152] }\end{array}$ & $396.1^{\circ} \mathrm{C}$ & $\begin{array}{l}\text { Parabolic } \\
\text { trough or } \\
\text { linear } \\
\text { Fresnel }\end{array}$ & $\begin{array}{l}\text { Dowtherm } \\
\text { A }\end{array}$ & - & $\begin{array}{l}- \\
(69.6 \% \\
\text { overall })\end{array}$ \\
\hline $\begin{array}{l}\text { Solar steam generation in series } \\
\text { with geothermal pre-heating - } \\
\text { district/industrial heat is } \\
\text { recovered after turbine via HX } \\
{[159]}\end{array}$ & - & $\begin{array}{l}\text { Parabolic } \\
\text { Trough }\end{array}$ & $\begin{array}{l}\text { Direct } \\
\text { steam } \\
\text { generation }\end{array}$ & - & $\begin{array}{l}7-11 \% \\
\text { (overall } \\
\text { electrical) }\end{array}$ \\
\hline
\end{tabular}




\begin{tabular}{|l|l|l|l|l|l|}
\hline $\begin{array}{l}\text { Solar thermal and geothermal } \\
\text { heat used in separate ORCs }- \\
\text { includes simultaneous } \\
\text { production of process heat } \\
{[160]}\end{array}$ & $320^{\circ} \mathrm{C}$ & $\begin{array}{l}\text { Parabolic } \\
\text { Trough }\end{array}$ & $\begin{array}{l}\text { Therminol } \\
\text { VP1 }\end{array}$ & - & $\begin{array}{l}- \\
(54.7 \% \\
\text { overall })\end{array}$ \\
\hline
\end{tabular}

\section{Hybridization with Photovoltaics}

Another common technology for hybridization with solar thermal is solar photovoltaic energy. Although both of these technologies use the same energy source (i.e., the sun), the combination of the two actually presents some fairly strong synergies. Photovoltaic cells can demonstrate varying performance with cell temperature, with higher temperatures resulting in degraded performance both in terms of efficiency and overall power output, as Figure 17 demonstrates for single-crystalline PV cells [161]. Because of these relationships, solar cells are generally designed to be cooled, either actively or passively [162] to keep them near their most efficient operating point.

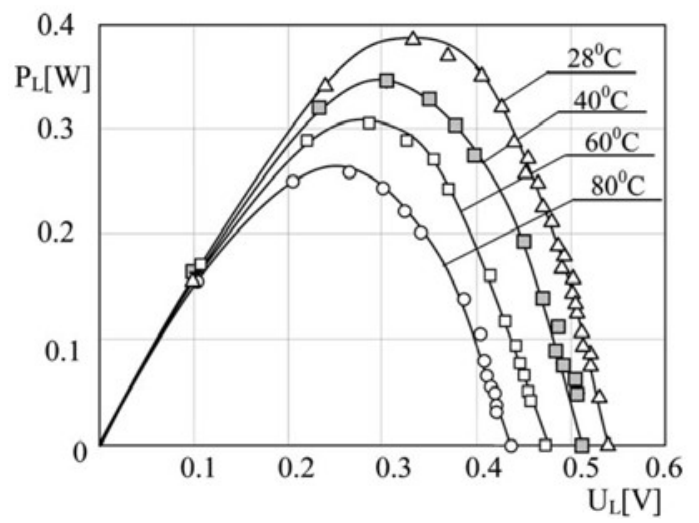

(a)

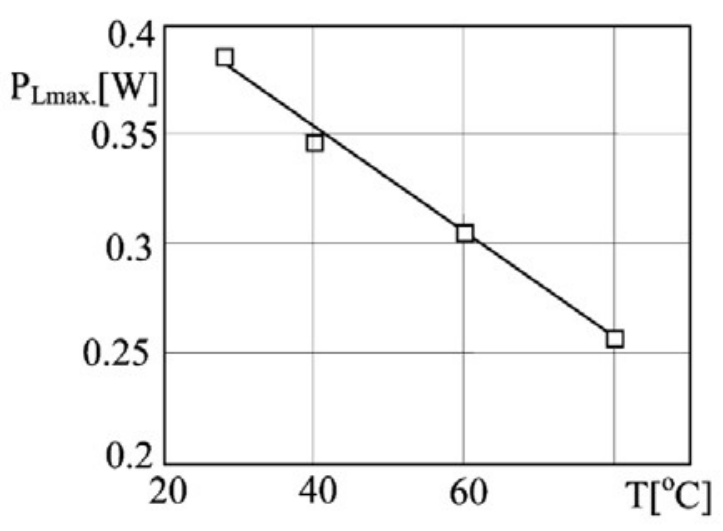

(b)

Figure 17: Degrading performance of single-crystalline silicon photovoltaic cells with temperature. Output power vs. voltage is shown in (a) with varying temperature. Maximum output power is shown vs. temperature in (b). Available from [161].

Instead of simply cooling the PV cells, cogeneration utilizes the otherwise wasted thermal energy, which can be utilized to increase the overall efficiency of the cell. This has given rise to photovoltaic thermal (PVT) solar collectors. Recent and comprehensive reviews of this hybrid technology are given by Makki et al. [163] and Michael et al. [164]. Because this technology generally uses PV for power generation and solar thermal energy predominantly for low temperature thermal applications (less than $100{ }^{\circ} \mathrm{C}$ ), this technology is fundamentally different from the other hybrids considered here, which utilize CSP predominantly for power generation. Therefore, PVT technologies are not covered comprehensively here. However, a brief overview of the methods for exploiting synergies in photovoltaic and solar thermal technologies is given. Makki et al. classify PVT technologies by their heat extraction mechanism into five categories: air-based, liquid-based, heat pipe-based, PCM-based, and thermoelectricbased [163]. Air and liquid-based PVT collectors have small channels at the back end of the PV cells (as shown in Figure 18), so that a fluid can flow through and absorb the excess heat generated, which has the 
effect of both cooling the PV cell to improve its efficiency and providing another source of energy, such as space heating [165-168] or water heating $[169,170]$.

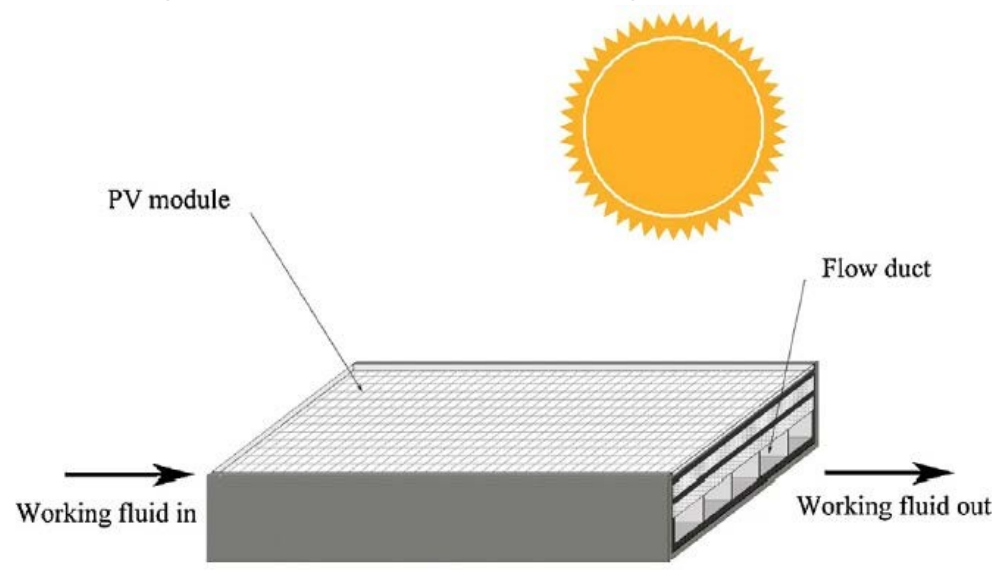

Figure 18: Schematic diagram of a PVT module used for water heating. Available from [170].

Heat pipes can also be used to remove heat from PVT modules. Heat pipes have high thermal conductivity as they use the evaporation and condensation of a fluid for efficient heat transfer. At the evaporator end, a heat source (which would be solar energy in the case of PVT) is used to evaporate the fluid, which then travels to the condensor side of the heat pipe (the heat sink), where the fluid is condensed and carried back to the evaporator by gravity, capillary action, or another means [171]. PVT modules with heat pipes have been proposed for applications such as district heating [172], or water heating for buildings [173].

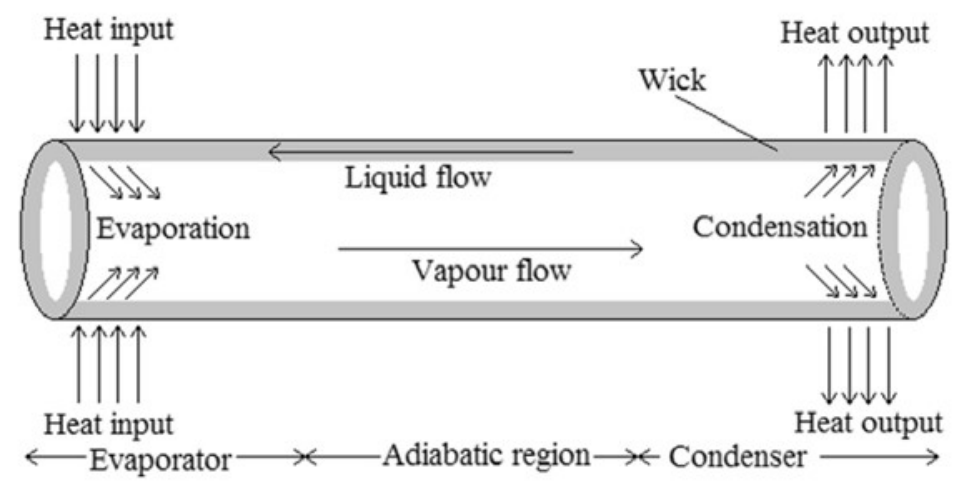

Figure 19: The structure of a heat pipe. Available from [171].

Phase change materials (PCMs) can also be integrated into PVT modules. PCMs use the energy stored in the phase change of a material to store energy. PVT technology combined with PCMs can be used for thermal energy storage with solar heat pumps [174,175] or directly in buildings $[176,177]$ to temporally shift the utilization of solar thermal energy. Thermoelectric generators (TEGs) can also be used to harvest the residual thermal energy from PV modules. A thermo-electric module is a solid-state semiconductor device that directly converts thermal energy into electrical energy using a phenomenon called the Seebeck effect, which is when an electromotive force is created by differing voltages caused by temperature differences in 
different materials $[163,178]$. Variations of designs employing PVT with TEGs may be better able to utilize the full solar spectrum than PV systems alone [179].

PVT technology essentially uses the principle of waste heat recovery to increase the overall efficiency of photovoltaic modules by finding other uses for the thermal heat that is generated from the sun. In the survey by Makki et al., thermal efficiencies as high as $63.7 \%$ were reported [163]. When combined with the effect of increasing the PV performance by removing heat which degrades its performance, PVT technologies show a lot of promise.

\section{Hybridization with Wind}

Because wind power generation technology is so different from conventional thermal generation technology that CSP is founded upon, opportunities to hybridize CSP with wind are less prevalent in literature. These hybrids would be considered weak hybrids as the CSP and wind technologies are typically only coupled at the grid level. Still, the combined power generation profiles of wind and CSP can provide benefits, such as a better fit for consumer demand [180] or improved grid stability [181]. A study by Vick and Moss showed that CSP was a match with wind farms to meet the electrical demand in the Texas Panhandle and they proposed a mix of $67 \%$ wind with 33\% CSP (6 hours of TES) to meet the electrical demand for that area. Although the hybrid was more expensive (on an LCOE basis) than a pure wind farm, it had better ability to meet peak demand than a pure wind farm [180]. Similarly, Reichling and Kulacki found that wind power had lower cost overall in a Minnesota case study, but electrical load matching favored the hybrid combination of wind and CSP [182]. Petrakopoulou et al. evaluated the ability of a CSP and wind farm hybrid to autonomously provide power to an island. This configuration again consists of hybridization at the grid level, but may have some additional synergy in co-locating the two technologies, such as reduced capital costs for transmission, due to the small size of the area served. This study found that the combination of technologies required battery storage on the wind farm side and TES on the CSP side with $48 \%$ of the power coming from the CSP [183]. Ghosh and Dincer explored using a solar-wind-geothermal hybrid system for multi-generation of electricity, cooling, water purification, process drying, and space heating. The purpose of the wind power in this study was to power a water pump for reverse osmosis, while the solar was used in power generation [153].

One key benefit of CSP with wind is its capability to store energy at a low cost using TES, which has the effect of helping to stabilize the grid by providing a semi-dispatchable power source. Thermal storage is such a benefit to CSP as a technology, that its direct use has also been proposed for use with wind to provide a stabilized power output [184], as shown in Figure 20. Although this configuration does not use solar, it does provide a rare example of the use of CSP technology to enhance wind power with hybridization at the component level, rather than

electrically at the grid level only. 


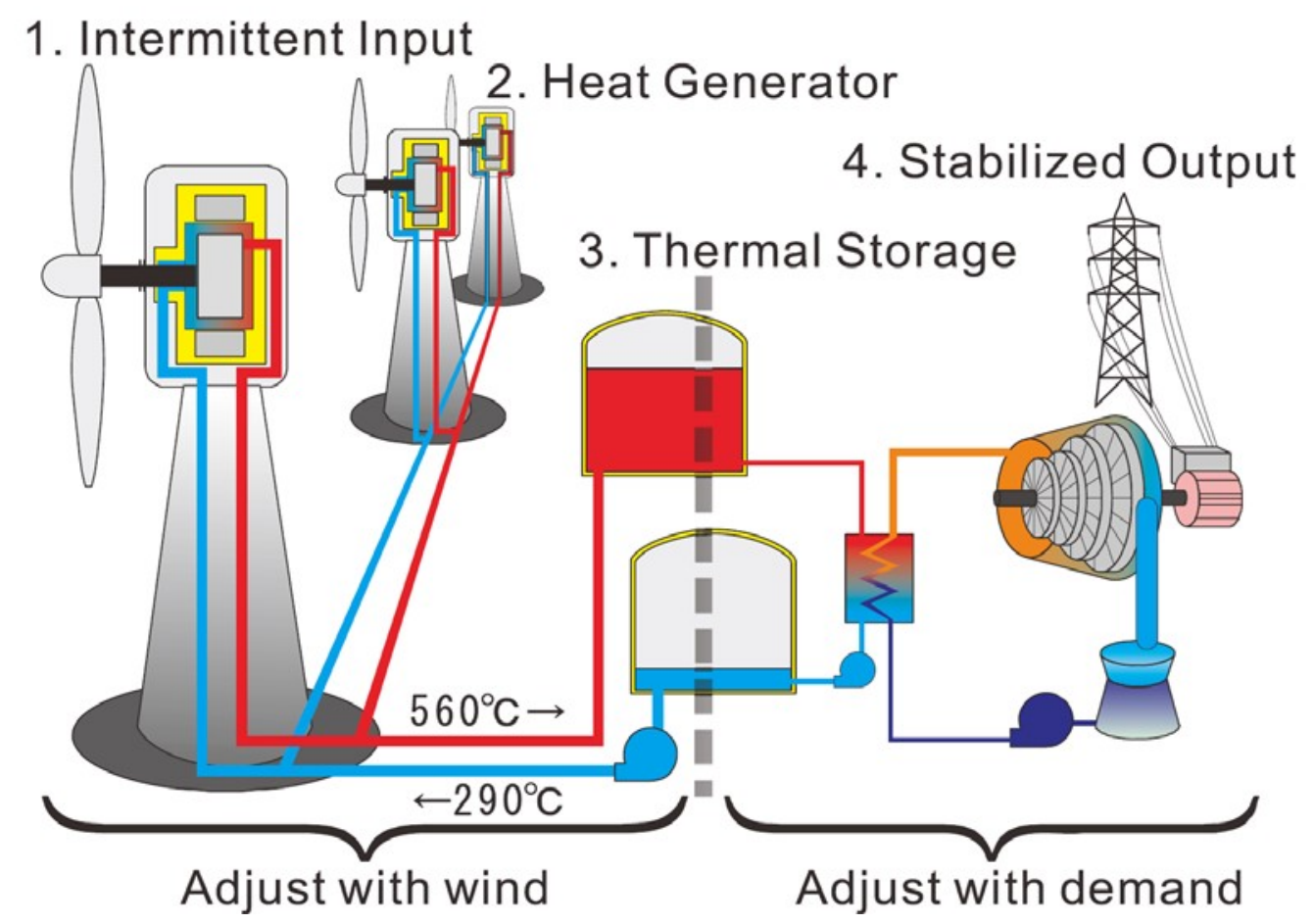

Figure 20: A wind power with TES configuration proposed by Okazaki et al. Available from [184]. The details of the studies on CSP-wind hybrids is shown in Table 5. Most studies of wind/CSP hybrids only demonstrate hybridization at the grid level, so the synergies between the two technologies are generally weak.

Table 5: A summary of CSP-wind hybrid systems

\begin{tabular}{|l|l|l|l|l|l|}
\hline Configuration & $\begin{array}{l}\text { Solar } \\
\text { collection } \\
\text { temp. }\end{array}$ & $\begin{array}{l}\text { Collector } \\
\text { type }\end{array}$ & $\begin{array}{l}\text { Solar heat } \\
\text { collection } \\
\text { fluid }\end{array}$ & $\begin{array}{l}\text { Solar } \\
\text { fraction }\end{array}$ & $\begin{array}{l}\text { Solar-to- } \\
\text { electricity } \\
\text { efficiency }\end{array}$ \\
\hline $\begin{array}{l}\text { CSP and wind hybridization at } \\
\text { grid level [182] }\end{array}$ & - & $\begin{array}{l}\text { Parabolic } \\
\text { trough }\end{array}$ & - & - & $\begin{array}{l}14 \% \\
\text { (annual) }\end{array}$ \\
\hline $\begin{array}{l}\text { CSP and wind hybridization at } \\
\text { grid level [180] }\end{array}$ & $400{ }^{\circ} \mathrm{C}$ & $\begin{array}{l}\text { Parabolic } \\
\text { trough }\end{array}$ & $\begin{array}{l}\text { Therminol } \\
\text { VP1 }\end{array}$ & - & $\begin{array}{l}16 \% \\
\text { (annual) }\end{array}$ \\
\hline $\begin{array}{l}\text { CSP and wind hybridization at } \\
\text { grid level [183] }\end{array}$ & $380^{\circ} \mathrm{C}+$ & $\begin{array}{l}\text { Parabolic } \\
\text { trough }\end{array}$ & $\begin{array}{l}\text { Therminol } \\
\text { VP1 }\end{array}$ & $\begin{array}{l}48 \% \\
(\text { annual) }\end{array}$ & $22.9 \%$ \\
\hline $\begin{array}{l}\text { Wind used for water pumping } \\
\text { in reverse osmosis system in } \\
\text { solar-geothermal-wind hybrid } \\
\text { multi-generation [153] }\end{array}$ & $350^{\circ} \mathrm{C}$ & $\begin{array}{l}\text { Parabolic } \\
\text { trough }\end{array}$ & - & - & $\begin{array}{l}- \\
(36.7 \% \\
\text { overall) }\end{array}$ \\
\hline
\end{tabular}

\section{Conclusion}

The advantages and disadvantages of various CSP hybrids are presented in Table 6. Hybridization of CSP with other energy sources has many advantages, but in some instances, hybridization may hinder CSP technology. CSP-wind hybrids (at least those configurations covered here), for example, don't have much synergy and are only considered hybrids in that the use of their outputs are planned together. While each technology has merit, it generally doesn't make much sense to combine them at the component level. CSP-geothermal hybrids have the 
potential to be an all-renewable option with dispatchability, although the low temperature power cycles required by geothermal severely limit the efficiency of the combined system. The overall efficiency can be improved by finding other uses for the low temperature heat, although the locations with adequate solar thermal resources, geothermal resources, and multiple low temperature heat sinks may be scarce. PVT technology has many positives and is an outlier in this context as it doesn't rely on solar thermal technology for power generation and may not be appropriate for centralized power generation, which would require co-location of a large plant as well as a useful heat sink for low temperature thermal energy. While this hybrid has many benefits, it does not inherently enhance dispatchability as both technologies (PV and solar thermal) still rely on an intermittent solar resource.

Hybridizing CSP with hydrocarbons has several benefits including enhanced dispatchability from the ability to combust fuel on demand. Using fossil fuels in a hybrid configuration prevents the system from being purely renewable and emission free, but may actually enhance the system's ability to harvest solar energy if the hybrid is designed to get higher efficiency by exploiting the synergies of the two forms of energy. Hybridization with biofuels has the potential for dispatchability and purely renewable generation, but would rely on cost-effective and abundant sources of biofuels. An ideal CSP-hybrid system would satisfy the following:

- Increases the efficiency of CSP component compared to stand-alone plant

- Reduces the LCOE of the CSP component compared to stand-alone plant

- Allows for flexible operation to achieve optimum performance

- Uses reliability of other energy source to achieve high capacity factor

- Can accommodate scalable solar field to achieve high solar share

- Achieves lower emissions compared to a hydrocarbon-based plant

There are many hurdles to achieving large-scale renewable power generation with cost competitiveness being chief among them. In the immediate future, adoption of renewable generation technologies at large scale will require adequate fossil fuel backup on the electric grid to account for fluctuations in renewable energy availability. Because the solution is currently a mix of many different energy technologies at the grid level, it makes sense to explore synergistic hybrids at the plant level that can enhance the overall efficiency and increase the usage of variable energy sources like solar energy. Further, hybridization will enable earlier and deeper penetration of renewable energy sources into the energy market. 
Table 6: A summary of the advantages and disadvantages of hybridizing CSP with other energy sources.

\begin{tabular}{|c|c|c|}
\hline & Advantages & Disadvantages \\
\hline Coal & $\begin{array}{l}\text { - Uses common, low cost linear } \\
\text { - } \text { concentrator technologies } \\
\text { - } \quad \text { Low costrofit existing coal plants } \\
\text { - } \text { Many possible injection points for } \\
\text { - } \text { solar at different temperatures } \\
\text { - Coal provides dispatchability } \\
\text { Capital cost savings from shared } \\
\text { equipment }\end{array}$ & $\begin{array}{l}\text { - High emission fuel } \\
\text { - } \quad \text { Equipment age mismatch may } \\
\text { be } \\
\text { issue for retrofit } \\
\text { - } \quad \text { Efficiency limited by Rankine } \\
\text { cycle power block } \\
\text { - High temp. gasification needs } \\
\text { tech. development }\end{array}$ \\
\hline $\begin{array}{l}\text { Natural } \\
\text { Gas }\end{array}$ & $\begin{array}{ll}\text { - } & \text { Low cost, abundant fuel } \\
\text { - } & \text { Low emission fuel } \\
\text { - } & \text { Many possible configurations } \\
\text { - } & \text { Eolfir at different temperatures } \\
\text { - } & \text { NG provides dispatchability } \\
\text { - } & \text { Capital cost savings from shared } \\
& \text { equipment }\end{array}$ & $\begin{array}{ll}\text { - } & \text { High temperature solar } \\
\text { technology still needs } \\
\text { development } \\
\text { - } \quad \text { Efficient ISCC has relatively } \\
\text { low solar share }\end{array}$ \\
\hline Biofuels & 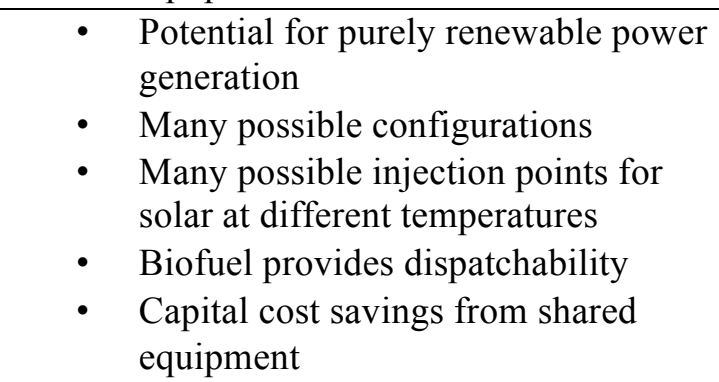 & $\begin{array}{l}\text { - Limited biofuel availability may } \\
\text { require other fuel sources } \\
\text { - High temp. gasification needs } \\
\text { tech. development }\end{array}$ \\
\hline Geothermal & $\begin{array}{ll}\text { - } & \text { Potential for purely renewable power } \\
\text { generation } \\
\text { - } \\
\text { Geothermal provides some } \\
\text { dispatchability } \\
\text { - Utilizes low temperature, low cost } \\
\text { - } \text { Solar collectors } \\
\text { Opportunities for multi-generation to } \\
\text { improve efficiency } \\
\text { Capital cost savings from shared } \\
\text { equipment }\end{array}$ & $\begin{array}{l}\text { Limited to low temperature, } \\
\text { inefficient power cycles } \\
\text { Multi-generation systems } \\
\text { require co-location of solar, } \\
\text { geothermal, and multiple heat } \\
\text { sinks } \\
\text { Geothermal brine can cause } \\
\text { corrosion and scaling issues on } \\
\text { solar equipment }\end{array}$ \\
\hline $\begin{array}{l}\text { Photo- } \\
\text { voltaic }\end{array}$ & 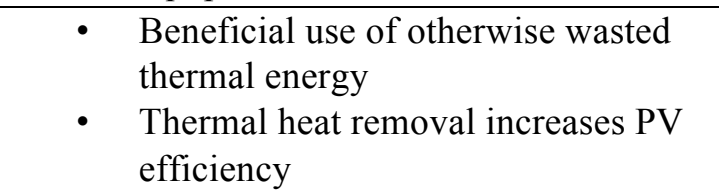 & $\begin{array}{ll}\text { - } & \text { Requires heat sink for thermal } \\
\text { energy } \\
\text { - }\end{array}$ \\
\hline Wind & $\begin{array}{ll}\text { - } & \text { Potential for purely renewable power } \\
\text { generation } \\
\text { - } \\
\text { Different energy availability profiles } \\
\text { provides some reliability }\end{array}$ & $\begin{array}{ll}\text { - } & \text { Energy sources not dispatchable } \\
\text { - } & \text { Little synergy at equipment level } \\
\text { as hybridization is generally } \\
\text { only at grid level } \\
\text { - } \quad \text { No capital cost savings from } \\
\text { shared equipment }\end{array}$ \\
\hline
\end{tabular}




\subsection{Future Research Directions}

Solar thermal energy for power generation has its share of challenges, both in research and in deployment of existing technology. Hybrid configurations that exploit synergies of solar thermal energy with other sources have the potential to provide both reliable and renewable power. These configurations should consider the overall efficiency of the plant so that, in cases where a combustible fuel is used, the fuel usage is minimized. Ideally these configurations would also be flexible, both in design and operation. From a design standpoint, designing plants so that the solar collector field can be expanded over time to provide an ever-increasing solar fraction would have many advantages. This type of plant could be technically and economically feasible at low solar fraction in the near future, but would also have the potential to become a nearly entirely renewable source of power as storage technology improves in the future. On the operation side, a plant with the ability to operate in a flexible mode (transitioning seamlessly between energy sources), has the potential to be optimized and further exploit synergies between the energy sources. Because solar energy is so variable, intelligent operation of a plant that maintains reliability while also pursuing optimality is a critical research area.

\section{Acronyms}

\begin{tabular}{|l|l|}
\hline CSP & Concentrated solar power \\
\hline DSG & Direct steam generation \\
\hline HRSG & Heat recovery steam generator \\
\hline HTF & Heat transfer fluid \\
\hline IGCC & Integrated Gasification Combined Cycle \\
\hline ISCC & Integrated Solar Combined Cycle \\
\hline LCOE & Levelized cost of electricity \\
\hline ORC & Organic Rankine cycle \\
\hline PCM & Phase-change material \\
\hline PVT & Photovoltaic thermal \\
\hline SPCC & $\begin{array}{l}\text { Solar-assisted post-combustion carbon } \\
\text { capture }\end{array}$ \\
\hline STIG & Steam injected gas turbine \\
\hline TEG & Thermoelectric generator \\
\hline TES & Thermal energy storage \\
\hline
\end{tabular}

\section{Definitions}

\begin{tabular}{|l|l|}
\hline Capacity factor or capacity utilization factor & $\begin{array}{l}\text { The fraction of power supplied by a plant } \\
\text { relative to its maximum capacity }\end{array}$ \\
\hline Cogeneration & $\begin{array}{l}\text { A plant that simultaneously produces electric } \\
\text { power and usable heat }\end{array}$ \\
\hline
\end{tabular}




\begin{tabular}{|l|l|}
\hline Direct steam generation & $\begin{array}{l}\text { A method of solar heat collection where steam } \\
\text { is generated directly in a solar collector }\end{array}$ \\
\hline Multi-generation or polygeneration & $\begin{array}{l}\text { A plant that simultaneously produces electric } \\
\text { power and other useful products such as heat, } \\
\text { cooling, chemicals, or purified water }\end{array}$ \\
\hline Overall efficiency & $\begin{array}{l}\text { The total efficiency of the plant with both } \\
\text { solar and other inputs }\end{array}$ \\
\hline Power Tower or Central Receiver & $\begin{array}{l}\text { A type of concentrated solar power plant } \\
\text { where an array of flat mirrors concentrate } \\
\text { sunlight at a single point, typically on top of a } \\
\text { tower }\end{array}$ \\
\hline Solar multiple & $\begin{array}{l}\text { The amount of solar energy available relative } \\
\text { to the amount required for full-capacity power } \\
\text { production in the power block. }\end{array}$ \\
\hline Solar share or solar fraction & $\begin{array}{l}\text { The fraction of the total energy to the plant } \\
\text { that is supplied by solar }\end{array}$ \\
\hline Solar-to-electric efficiency & $\begin{array}{l}\text { The marginal efficiency of the plant when } \\
\text { adding solar power }\end{array}$ \\
\hline Stand-alone plant & A plant that relies on a single energy source \\
\hline
\end{tabular}




\section{References}

[1] Denholm P, Hand M. Grid flexibility and storage required to achieve very high penetration of variable renewable electricity. Energy Policy 2011;39:1817-30. doi:10.1016/j.enpol.2011.01.019.

[2] Crawford J. The California `Duck Curve' That Will Jolt Its Power Grid. Bloom Bus 2015. $\mathrm{http}: / /$ www.bloomberg.com/news/articles/2015-10-21/california-s-duck-curve-is-about-to-jolt-theelectricitygrid (accessed February 3, 2016).

[3] Peterseim JH, White S, Tadros A, Hellwig U. Concentrated solar power hybrid plants, which technologies are best suited for hybridisation? Renew Energy 2013;57:520-32. doi:10.1016/j.renene.2013.02.014.

[4] Peterseim JH, White S, Tadros A, Hellwig U. Concentrating solar power hybrid plants - Enabling cost effective synergies. Renew Energy 2014;67:178-85. doi:10.1016/j.renene.2013.11.037.

[5] Popov D. An option for solar thermal repowering of fossil fuel fired power plants. Sol Energy 2011;85:3449. doi:10.1016/j.solener.2010.11.017.

[6] Zhai R, Li C, Chen Y, Yang Y, Patchigolla K, Oakey JE. Life cycle assessment of solar aided coal-fired power system with and without heat storage. Energy Convers Manag 2016;111:453-65. doi:10.1016/j.enconman.2015.12.053.

[7] Pierce W, Gauché P, von Backström T, Brent AC, Tadros A. A comparison of solar aided power generation (SAPG) and stand-alone concentrating solar power (CSP): A South African case study. Appl Therm Eng 2013;61:657-62. doi:10.1016/j.applthermaleng.2013.08.014.

[8] Libby C, Golden J, Bedilion R, Turchi C. Assessment of Direct Steam Generation Technologies for Solar Thermal Augmented Steam Cycle Applications. Energy Procedia 2014;49:1420-8. doi:10.1016/j.egypro.2014.03.151.

[9] Zhang M, Du X, Pang L, Xu C, Yang L. Performance of double source boiler with coal-fired and solar power tower heat for supercritical power generating unit. Energy 2016;104:64-75. doi:10.1016/j.energy.2016.03.111.

[10] Feng L, Chen H, Zhou Y, Zhang S, Yang T, An L. The development of a thermo-economic evaluation method for solar aided power generation. Energy Convers Manag 2016;116:112-9. doi:10.1016/j.enconman.2016.01.072.

[11] Zhai R, Peng P, Yang Y, Zhao M. Optimization study of integration strategies in solar aided coal-fired power generation system. Renew Energy 2014;68:80-6. doi:10.1016/j.renene.2014.01.032.

[12] Wang F, Li H, Zhao J, Deng S, Yan J. Technical and economic analysis of integrating low-medium temperature solar energy into power plant. Energy Convers Manag 2016;112:459-69. doi:10.1016/j.enconman.2016.01.037.

[13] Wu J, Hou H, Yang Y, Hu E. Annual performance of a solar aided coal-fired power generation system (SACPG) with various solar field areas and thermal energy storage capacity. Appl Energy 2015;157:123-33. doi:10.1016/j.apenergy.2015.08.022.

[14] Wu J, Hou H, Yang Y. Annual economic performance of a solar-aided 600MW coal-fired power generation system under different tracking modes, aperture areas, and storage capacities. Appl Therm Eng 2016;104:319-32. doi:10.1016/j.applthermaleng.2016.05.057.

[15] Zhao Y, Hong H, Jin H. Mid and low-temperature solar-coal hybridization mechanism and validation. Energy 2014;74:78-87. doi:10.1016/j.energy.2014.03.092.

[16] Hong H, Peng S, Zhao Y, Liu Q, Jin H. A Typical Solar-coal Hybrid Power Plant in China. Energy Procedia 2014;49:1777-83. doi:10.1016/j.egypro.2014.03.188.

[17] Peng S, Wang Z, Hong H, Xu D, Jin H. Exergy evaluation of a typical 330MW solar-hybrid coal-fired power plant in China. Energy Convers Manag 2014;85:848-55. doi:10.1016/j.enconman.2013.12.073.

[18] Zhai R, Liu H, Li C, Zhao M, Yang Y. Analysis of a solar-aided coal-fired power generation system based on thermo-economic structural theory. Energy 2016;102:375-87. doi:10.1016/j.energy.2016.02.086.

[19] Zhao Y, Hong H, Jin H. Optimization of the solar field size for the solar-coal hybrid system. Appl Energy 2016. doi:10.1016/j.apenergy.2016.01.069.

[20] Yan Q, Hu E, Zhai R. Evaluation of solar aided thermal power generation with various power plants. Int J Energy Res 2011;35:909-22. doi:10.1002/er.1748.

[21] Zhu Y, Zhai R, Zhao M, Yang Y, Yan Q. Evaluation methods of solar contribution in solar aided coal-fired power generation system. Energy Convers Manag 2015;102:209-16. doi:10.1016/j.enconman.2015.01.046. 
[22] Zhao Y, Hong H, Jin H. Thermo-economic Optimization of Solar-Coal Hybrid Systems. Energy Procedia 2015;75:457-61. doi:10.1016/j.egypro.2015.07.419.

[23] Prosin T, Pryor T, Creagh C, Amsbeck L, Buck R. Hybrid Solar and Coal-fired Steam Power Plant with Air Preheating Using a Centrifugal Solid Particle Receiver. Energy Procedia 2015;69:1371-81. doi:10.1016/j.egypro.2015.03.134.

[24] Sreenivasulu B, Gayatri DV, Sreedhar I, Raghavan KV. A journey into the process and engineering aspects of carbon capture technologies. Renew Sustain Energy Rev 2015;41:1324-50.

doi:10.1016/j.rser.2014.09.029.

[25] Luis P. Use of monoethanolamine (MEA) for $\mathrm{CO} 2$ capture in a global scenario: Consequences and alternatives. Desalination 2016;380:93-9. doi:10.1016/j.desal.2015.08.004.

[26] Chu F, Yang L, Du X, Yang Y. CO2 capture using MEA (monoethanolamine) aqueous solution in coal-fired power plants: Modeling and optimization of the absorbing columns. Energy 2016;109:495-505. doi:10.1016/j.energy.2016.04.123.

[27] Vasudevan S, Farooq S, Karimi IA, Saeys M, Quah MCG, Agrawal R. Energy penalty estimates for CO2 capture: Comparison between fuel types and capture-combustion modes. Energy 2016;103:709-14. doi:10.1016/j.energy.2016.02.154.

[28] Thorbjörnsson A, Wachtmeister H, Wang J, Höök M. Carbon capture and coal consumption: Implications of energy penalties and large scale deployment. Energy Strateg Rev 2015;7:18-28. doi:10.1016/j.esr.2014.12.001.

[29] Jenni KE, Baker ED, Nemet GF. Expert elicitations of energy penalties for carbon capture technologies. Int J Greenh Gas Control 2013;12:136-45. doi:10.1016/j.ijggc.2012.11.022.

[30] Goto K, Yogo K, Higashii T. A review of efficiency penalty in a coal-fired power plant with postcombustion CO2 capture. Appl Energy 2013;111:710-20. doi:10.1016/j.apenergy.2013.05.020.

[31] Wang F, Zhao J, Li H, Li H, Zhao L, Yan J. Experimental Study of Solar Assisted Post-combustion Carbon Capture. Energy Procedia 2015;75:2246-52. doi:10.1016/j.egypro.2015.07.401.

[32] Parvareh F, Sharma M, Qadir A, Milani D, Khalilpour R, Chiesa M, et al. Integration of solar energy in coal-fired power plants retrofitted with carbon capture: A review. Renew Sustain Energy Rev 2014;38:1029-44. doi:10.1016/j.rser.2014.07.032.

[33] Zhao Y, Hong H, Zhang X, Jin H. Integrating mid-temperature solar heat and post-combustion CO2-capture in a coal-fired power plant. Sol Energy 2012;86:3196-204. doi:10.1016/j.solener.2012.08.002.

[34] Brodrick PG, Kang CA, Brandt AR, Durlofsky LJ. Optimization of carbon-capture-enabled coal-gas-solar power generation. Energy 2015;79:149-62. doi:10.1016/j.energy.2014.11.003.

[35] Carapellucci R, Giordano L, Vaccarelli M. Analysis of CO2 Post-combustion Capture in Coal-fired Power Plants Integrated with Renewable Energies. Energy Procedia 2015;82:350-7. doi:10.1016/j.egypro.2015.11.801.

[36] Qadir A, Mokhtar M, Khalilpour R, Milani D, Vassallo A, Chiesa M, et al. Potential for solar-assisted postcombustion carbon capture in Australia. Appl Energy 2013;111:175-85. doi:10.1016/j.apenergy.2013.04.079.

[37] Ordorica-Garcia, G, Delgado AV, Garcia AF. Novel integration options of concentrating solar thermal technology with fossil-fuelled and CO2 capture processes. Energy Procedia 2011;4:809-16. doi:10.1016/j.egypro.2011.01.123.

[38] Qadir A, Carter L, Wood T, Abbas A. Economic and policy evaluation of SPCC (solar-assisted postcombustion carbon capture) in Australia. Energy 2015;93:294-308. doi:10.1016/j.energy.2015.08.090.

[39] Liu L, Zhao J, Deng S, An Q. A technical and economic study on solar-assisted ammonia-based postcombustion CO2 capture of power plant. Appl Therm Eng 2016;102:412-22. doi:10.1016/j.applthermaleng.2016.03.154.

[40] Zedtwitz P v., Petrasch J, Trommer D, Steinfeld A. Hydrogen production via the solar thermal decarbonization of fossil fuels. Sol Energy 2006;80:1333-7. doi:10.1016/j.solener.2005.06.007.

[41] Mahinpey N, Gomez A. Review of gasification fundamentals and new findings: Reactors, feedstock, and kinetic studies. Chem Eng Sci 2016;148:14-31. doi:10.1016/j.ces.2016.03.037.

[42] Gokon N, Izawa T, Kodama T. Steam gasification of coal cokes by internally circulating fluidized-bed reactor by concentrated Xe-light radiation for solar syngas production. Energy 2015;79:264-72. doi:10.1016/j.energy.2014.11.012. 
[43] Gokon N, Izawa T, Abe T, Kodama T. Steam gasification of coal cokes in an internally circulating fluidized bed of thermal storage material for solar thermochemical processes. Int J Hydrogen Energy 2014;39:11082_ 93. doi:10.1016/j.ijhydene.2014.05.124.

[44] Lee MC, Yoon J, Joo S, Yoon Y. Gas turbine combustion characteristics of H2/CO synthetic gas for coal integrated gasification combined cycle applications. Int J Hydrogen Energy 2015;40:11032-45. doi:10.1016/j.ijhydene.2015.06.086.

[45] Cormos C-C, Cormos A-M, Serban Agachi P. Techno-economical and environmental evaluations of IGCC power generation process with carbon capture and storage (CCS). Comput. Aided Chem. Eng., vol. 29, 2011, p. 1678-82. doi:10.1016/B978-0-444-54298-4.50114-8.

[46] Yadav D, Banerjee R. A review of solar thermochemical processes. Renew Sustain Energy Rev 2016;54:497-532. doi:10.1016/j.rser.2015.10.026.

[47] Z'Graggen A, Steinfeld A. Hydrogen production by steam-gasification of carbonaceous materials using concentrated solar energy - V. Reactor modeling, optimization, and scale-up. Int J Hydrogen Energy 2008;33:5484-92. doi:10.1016/j.ijhydene.2008.07.047.

[48] Z'Graggen A, Steinfeld A. A two-phase reactor model for the steam-gasification of carbonaceous materials under concentrated thermal radiation. Chem Eng Process Process Intensif 2008;47:655-62. doi:10.1016/j.cep.2006.12.003.

[49] Z'Graggen A, Haueter P, Maag G, Romero M, Steinfeld A. Hydrogen production by steam-gasification of carbonaceous materials using concentrated solar energy-IV. Reactor experimentation with vacuum residue. Int J Hydrogen Energy 2008;33:679-84. doi:10.1016/j.ijhydene.2007.10.038.

[50] Z'Graggen A, Steinfeld A. Heat and mass transfer analysis of a suspension of reacting particles subjected to concentrated solar radiation - Application to the steam-gasification of carbonaceous materials. Int J Heat Mass Transf 2009;52:385-95. doi:10.1016/j.ijheatmasstransfer.2008.05.023.

[51] Martinek J, Bingham C, Weimer AW. Computational modeling of a multiple tube solar reactor with specularly reflective cavity walls. Part 2: Steam gasification of carbon. Chem Eng Sci 2012;81:285-97. doi:10.1016/j.ces.2012.06.065.

[52] Ng YC, Lipiński W. Thermodynamic analyses of solar thermal gasification of coal for hybrid solar-fossil power and fuel production. Energy 2012;44:720-31. doi:10.1016/j.energy.2012.05.019.

[53] Ozturk M, Dincer I. Thermodynamic assessment of an integrated solar power tower and coal gasification system for multi-generation purposes. Energy Convers Manag 2013;76:1061-72.

doi:10.1016/j.enconman.2013.08.061.

[54] Shrivastava A, Prabu V. Thermodynamic analysis of solar energy integrated underground coal gasification in the context of cleaner fossil power generation. Energy Convers Manag 2016;110:67-77. doi:10.1016/j.enconman.2015.12.009.

[55] Tsoutsanis E, Meskin N, Benammar M, Khorasani K. A dynamic prognosis scheme for flexible operation of gas turbines. Appl Energy 2016;164:686-701. doi:10.1016/j.apenergy.2015.11.104.

[56] Kitzmiller K, Miller F. Effect of Variable Guide Vanes and Natural Gas Hybridization for Accommodating Fluctuations in Solar Input to a Gas Turbine. J Sol Energy Eng 2012;134:41008.

[57] Klein P, Roos TH, Sheer TJ. Parametric analysis of a high temperature packed bed thermal storage design for a solar gas turbine. Sol Energy 2015;118:59-73. doi:10.1016/j.solener.2015.05.008.

[58] Grange B, Dalet C, Falcoz Q, Ferrière A, Flamant G. Impact of thermal energy storage integration on the performance of a hybrid solar gas-turbine power plant. Appl Therm Eng 2016;105:266-75. doi:10.1016/j.applthermaleng.2016.05.175.

[59] Quero M, Korzynietz R, Ebert M, Jiménez AA, del Río A, Brioso JA. Solugas - Operation Experience of the First Solar Hybrid Gas Turbine System at MW Scale. Energy Procedia 2014;49:1820-30. doi:10.1016/j.egypro.2014.03.193.

[60] Korzynietz R, Brioso JA, del Río A, Quero M, Gallas M, Uhlig R, et al. Solugas - Comprehensive analysis of the solar hybrid Brayton plant. Sol Energy 2016;135:578-89. doi:10.1016/j.solener.2016.06.020.

[61] Semprini S, Sánchez D, De Pascale A. Performance analysis of a micro gas turbine and solar dish integrated system under different solar-only and hybrid operating conditions. Sol Energy 2016;132:279-93. doi:10.1016/j.solener.2016.03.012.

[62] Aichmayer L, Spelling J, Laumert B. Thermoeconomic Analysis of a Solar Dish Micro Gas-turbine Combined-cycle Power Plant. Energy Procedia 2015;69:1089-99. doi:10.1016/j.egypro.2015.03.217. 
[63] Aichmayer L, Spelling J, Laumert B. Preliminary design and analysis of a novel solar receiver for a micro gas-turbine based solar dish system. Sol Energy 2015;114:378-96. doi:10.1016/j.solener.2015.01.013.

[64] Coogan S, Brun K, Teraji D. Micromix Combustor for High Temperature Hybrid Gas Turbine Concentrated Solar Power Systems. Energy Procedia 2014;49:1298-307. doi:10.1016/j.egypro.2014.03.139.

[65] Cameretti MC, Langella G, Sabino S, Tuccillo R. Modeling of a Hybrid Solar Micro Gas-turbine Power Plant. Energy Procedia 2015;82:833-40. doi:10.1016/j.egypro.2015.11.820.

[66] Barigozzi G, Bonetti G, Franchini G, Perdichizzi A, Ravelli S. Thermal performance prediction of a solar hybrid gas turbine. Sol Energy 2012;86:2116-27. doi:10.1016/j.solener.2012.04.014.

[67] Ragnolo G, Aichmayer L, Wang W, Strand T, Laumert B. Technoeconomic Design of a Micro Gas-turbine for a Solar Dish System. Energy Procedia 2015;69:1133-42. doi:10.1016/j.egypro.2015.03.182.

[68] Sánchez-Orgaz S, Medina A, Calvo Hernández A. Recuperative solar-driven multi-step gas turbine power plants. Energy Convers Manag 2013;67:171-8. doi:10.1016/j.enconman.2012.11.006.

[69] Fernández P, Miller F. Assessment of the Overall Efficiency of Gas Turbine-driven CSP Plants Using Small Particle Solar Receivers. Energy Procedia 2014;49:334-43. doi:10.1016/j.egypro.2014.03.036.

[70] Santos MJ, Merchán RP, Medina A, Calvo Hernández A. Seasonal thermodynamic prediction of the performance of a hybrid solar gas-turbine power plant. Energy Convers Manag 2016;115:89-102. doi:10.1016/j.enconman.2016.02.019.

[71] Mokheimer EMA, Dabwan YN, Habib MA. Optimal integration of solar energy with fossil fuel gas turbine cogeneration plants using three different CSP technologies in Saudi Arabia. Appl Energy 2015. doi:10.1016/j.apenergy.2015.12.029.

[72] Al-attab KA, Zainal ZA. Externally fired gas turbine technology: A review. Appl Energy 2015;138:474-87. doi:10.1016/j.apenergy.2014.10.049.

[73] Olivenza-León D, Medina A, Calvo Hernández A. Thermodynamic modeling of a hybrid solar gas-turbine power plant. Energy Convers Manag 2015;93:435-47. doi:10.1016/j.enconman.2015.01.027.

[74] Olumayegun O, Wang M, Kelsall G. Closed-cycle gas turbine for power generation: A state-of-the-art review. Fuel 2016;180:694-717. doi:10.1016/j.fuel.2016.04.074.

[75] Livshits M, Kribus A. Solar hybrid steam injection gas turbine (STIG) cycle. Sol Energy 2012;86:190-9. doi:10.1016/j.solener.2011.09.020.

[76] Polonsky G, Kribus A. Performance of the solar hybrid STIG cycle with latent heat storage. Appl Energy 2015;155:791-803. doi:10.1016/j.apenergy.2015.06.067.

[77] Selwynraj AI, Iniyan S, Polonsky G, Suganthi L, Kribus A. Exergy analysis and annual exergetic performance evaluation of solar hybrid STIG (steam injected gas turbine) cycle for Indian conditions. Energy 2015;80:414-27. doi:10.1016/j.energy.2014.12.001.

[78] Selwynraj IA, Iniyan S, Polonsky G, Suganthi L, Kribus A. An economic analysis of solar hybrid steam injected gas turbine (STIG) plant for Indian conditions. Appl Therm Eng 2015;75:1055-64. doi:10.1016/j.applthermaleng.2014.10.055.

[79] Selwynraj AI, Iniyan S, Suganthi L, Livshits M, Polonsky G, Kribus A. Annual energy and environment analysis of solarized steam injection gas turbine (STIG) cycle for Indian regions. Appl Therm Eng 2016;94:679-96. doi:10.1016/j.applthermaleng.2015.10.106.

[80] Selwynraj AI, Iniyan S, Suganthi L, Livshits M, Polonsky G, Kribus A. Annual Thermodynamic Analysis of Solar Power with Steam Injection Gas Turbine (STIG) Cycle for Indian Conditions. Energy Procedia 2014;57:2920-9. doi:10.1016/j.egypro.2014.10.327.

[81] Polonsky G, Livshits M, Immanuel Selwynraj A, Iniyan S, Suganthi L, Kribus A. Annual performance of the solar hybrid STIG cycle. Sol Energy 2014;107:278-91. doi:10.1016/j.solener.2014.05.022.

[82] Bianchini A, Pellegrini M, Saccani C. Solar steam reforming of natural gas integrated with a gas turbine power plant: Economic assessment. Sol Energy 2015;122:1342-53. doi:10.1016/j.solener.2015.10.046.

[83] Bianchini A, Pellegrini M, Saccani C. Solar steam reforming of natural gas integrated with a gas turbine power plant. Sol Energy 2013;96:46-55. doi:10.1016/j.solener.2013.06.030.

[84] Niknia I, Yaghoubi M. Transient simulation for developing a combined solar thermal power plant. Appl Therm Eng 2012;37:196-207. doi:10.1016/j.applthermaleng.2011.11.016.

[85] Peterseim JH, Veeraragavan A. Solar Towers with Supercritical Steam Parameters - is the Efficiency Gain worth the Effort? Energy Procedia 2015;69:1123-32. doi:10.1016/j.egypro.2015.03.181.

[86] Gobereit B, Amsbeck L, Buck R, Pitz-Paal R, Röger M, Müller-Steinhagen H. Assessment of a falling solid particle receiver with numerical simulation. Sol Energy 2015;115:505-17. 
doi:10.1016/j.solener.2015.03.013.

[87] Powell KM, Edgar TF. Control of a large scale solar thermal energy storage system. Proc. 2011 Am. Control Conf., IEEE; 2011, p. 1530-5. doi:10.1109/ACC.2011.5991593.

[88] Powell KM, Edgar TF. Modeling and control of a solar thermal power plant with thermal energy storage. Chem Eng Sci 2012;71:138-45. doi:10.1016/j.ces.2011.12.009.

[89] Powell KM, Hedengren JD, Edgar TF. Dynamic optimization of a solar thermal energy storage system over a 24 hour period using weather forecasts. 2013 Am. Control Conf., IEEE; 2013, p. 2946-51. doi:10.1109/ACC.2013.6580282.

[90] Powell KM, Hedengren JD, Edgar TF. Dynamic optimization of a hybrid solar thermal and fossil fuel system. Sol Energy 2014;108:210-8. doi:10.1016/j.solener.2014.07.004.

[91] Cole WJ, Powell KM, Edgar TF. Optimization and advanced control of thermal energy storage systems. Rev Chem Eng 2012;28:81-99. doi:10.1515/revce-2011-0018.

[92] Edgar TF, Powell KM. Energy intensification using thermal storage. Curr Opin Chem Eng 2015;9:83-8. doi:10.1016/j.coche.2015.11.002.

[93] Behar O, Khellaf A, Mohammedi K, Ait-Kaci S. A review of integrated solar combined cycle system (ISCCS) with a parabolic trough technology. Renew Sustain Energy Rev 2014;39:223-50. doi:10.1016/j.rser.2014.07.066.

[94] Okoroigwe E, Madhlopa A. An integrated combined cycle system driven by a solar tower: A review. Renew Sustain Energy Rev 2016;57:337-50. doi:10.1016/j.rser.2015.12.092.

[95] Alqahtani BJ, Patiño-Echeverri D. Integrated Solar Combined Cycle Power Plants: Paving the way for thermal solar. Appl Energy 2016;169:927-36. doi:10.1016/j.apenergy.2016.02.083.

[96] Zhu G, Neises T, Turchi C, Bedilion R. Thermodynamic evaluation of solar integration into a natural gas combined cycle power plant. Renew Energy 2015;74:815-24. doi:10.1016/j.renene.2014.08.073.

[97] Manente G, Rech S, Lazzaretto A. Optimum choice and placement of concentrating solar power technologies in integrated solar combined cycle systems. Renew Energy 2016;96:172-89. doi:10.1016/j.renene.2016.04.066.

[98] Manente G. High performance integrated solar combined cycles with minimum modifications to the combined cycle power plant design. Energy Convers Manag 2016;111:186-97. doi:10.1016/j.enconman.2015.12.079.

[99] Antonanzas J, Jimenez E, Blanco J, Antonanzas-Torres F. Potential solar thermal integration in Spanish combined cycle gas turbines. Renew Sustain Energy Rev 2014;37:36-46. doi:10.1016/j.rser.2014.05.006.

[100] Corona B, Ruiz D, Miguel GS. Environmental Assessment of a HYSOL CSP Plant Compared to a Conventional Tower CSP Plant. Procedia Comput Sci 2016;83:1110-7. doi:10.1016/j.procs.2016.04.231.

[101] Nielsen LH, Skytte K, Cabrera Pérez CH, García EC, Barrio DL, Cuadrado LG, et al. Feasibility Study on HYSOL CSP. Procedia Comput Sci 2016;83:1157-63. doi:10.1016/j.procs.2016.04.238.

[102] Corona B, San Miguel G. Environmental analysis of a Concentrated Solar Power (CSP) plant hybridised with different fossil and renewable fuels. Fuel 2015;145:63-9. doi:10.1016/j.fuel.2014.12.068.

[103] Brown D, Tegrotenhuis W, Wegeng R, Mankins J. Solar Powered Steam-methane Reformer Economics. Energy Procedia 2014;49:1916-21. doi:10.1016/j.egypro.2014.03.203.

[104] Zheng R, Diver R, Caldwell D, Fritz B, Cameron R, Humble P, et al. Integrated Solar Thermochemical Reaction System for Steam Methane Reforming. Energy Procedia 2015;69:1192-200. doi:10.1016/j.egypro.2015.03.204.

[105] De Falco M, Giaconia A, Marrelli L, Tarquini P, Grena R, Caputo G. Enriched methane production using solar energy: an assessment of plant performance. Int J Hydrogen Energy 2009;34:98-109. doi:10.1016/j.ijhydene.2008.09.085.

[106] von Storch H, Roeb M, Stadler H, Sattler C, Hoffschmidt B. Available online Efficiency potential of indirectly heated solar reforming with different types of solar air receivers. Appl Therm Eng 2016;92:202-9. doi:10.1016/j.applthermaleng.2015.09.065.

[107] Servert JF, Cerrajero E, López D, Yagüe S, Gutierrez F, Lasheras M, et al. Base Case Analysis of a HYSOL Power Plant. Energy Procedia 2015;69:1152-9. doi:10.1016/j.egypro.2015.03.187.

[108] Domínguez R, Conejo AJ, Carrión M. Operation of a fully renewable electric energy system with CSP plants. Appl Energy 2014;119:417-30. doi:10.1016/j.apenergy.2014.01.014. 
[109] San Miguel G, Corona B. Hybridizing concentrated solar power (CSP) with biogas and biomethane as an alternative to natural gas: Analysis of environmental performance using LCA. Renew Energy 2014;66:580 7. doi:10.1016/j.renene.2013.12.023.

[110] Peterseim JH, Herr A, Miller S, White S, O'Connell DA. Concentrating solar power/alternative fuel hybrid plants: Annual electricity potential and ideal areas in Australia. Energy 2014;68:698-711. doi:10.1016/j.energy.2014.02.068.

[111] Lu Y, Zhao L, Guo L. Technical and economic evaluation of solar hydrogen production by supercritical water gasification of biomass in China. Int J Hydrogen Energy 2011;36:14349-59. doi:10.1016/j.ijhydene.2011.07.138.

[112] Liao B, Guo LJ. Concentrating Solar Thermochemical Hydrogen Production by Biomass Gasification in Supercritical Water. Energy Procedia 2015;69:444-50. doi:10.1016/j.egypro.2015.03.051.

[113] Hou Z, Zheng D. Solar utility and renewability evaluation for biodiesel production process. Appl Therm Eng 2009;29:3169-74. doi:10.1016/j.applthermaleng.2009.04.020.

[114] Nzihou A, Flamant G, Stanmore B. Synthetic fuels from biomass using concentrated solar energy - A review. Energy 2012;42:121-31. doi:10.1016/j.energy.2012.03.077.

[115] Manenti F, Leon-Garzon AR, Ravaghi-Ardebili Z, Pirola C. Assessing thermal energy storage technologies of concentrating solar plants for the direct coupling with chemical processes. The case of solar-driven biomass gasification. Energy 2014;75:45-52. doi:10.1016/j.energy.2014.04.044.

[116] Peterseim JH, Hellwig U, Tadros A, White S. Hybridisation optimization of concentrating solar thermal and biomass power generation facilities. Sol Energy 2014;99:203-14. doi:10.1016/j.solener.2013.10.041.

[117] Peterseim JH, Tadros A, Hellwig U, White S. Increasing the efficiency of parabolic trough plants using thermal oil through external superheating with biomass. Energy Convers Manag 2014;77:784-93. doi:10.1016/j.enconman.2013.10.022.

[118] Coelho B, Oliveira A, Schwarzbözl P, Mendes A. Biomass and central receiver system (CRS) hybridization: Integration of syngas/biogas on the atmospheric air volumetric CRS heat recovery steam generator duct burner. Renew Energy 2015;75:665-74. doi:10.1016/j.renene.2014.10.054.

[119] Colmenar-Santos A, Bonilla-Gómez J-L, Borge-Diez D, Castro-Gil M. Hybridization of concentrated solar power plants with biogas production systems as an alternative to premiums: The case of Spain. Renew Sustain Energy Rev 2015;47:186-97. doi:10.1016/j.rser.2015.03.061.

[120] Reddy KS, Aravindhan S, Mallick TK. Investigation of performance and emission characteristics of a biogas fuelled electric generator integrated with solar concentrated photovoltaic system. Renew Energy 2016;92:233-43. doi:10.1016/j.renene.2016.02.008.

[121] Peterseim JH, Tadros A, White S, Hellwig U, Landler J, Galang K. Solar Tower-biomass Hybrid Plants Maximizing Plant Performance. Energy Procedia 2014;49:1197-206. doi:10.1016/j.egypro.2014.03.129.

[122] Pikra G, Salim A, Prawara B, Purwanto AJ, Admono T, Eddy Z. Development of Small Scale Concentrated Solar Power Plant Using Organic Rankine Cycle for Isolated Region in Indonesia. Energy Procedia 2013;32:122-8. doi:10.1016/j.egypro.2013.05.016.

[123] Sterrer R, Schidler S, Schwandt O, Franz P, Hammerschmid A. Theoretical Analysis of the Combination of CSP with a Biomass CHP-plant Using ORC-technology in Central Europe. Energy Procedia 2014;49:1218 27. doi:10.1016/j.egypro.2014.03.131.

[124] Melchior T, Perkins C, Lichty P, Weimer AW, Steinfeld A. Solar-driven biochar gasification in a particleflow reactor. Chem Eng Process Process Intensif 2009;48:1279-87. doi:10.1016/j.cep.2009.05.006.

[125] Hathaway BJ, Honda M, Kittelson DB, Davidson JH. Steam gasification of plant biomass using molten carbonate salts. Energy 2013;49:211-7. doi:10.1016/j.energy.2012.11.006.

[126] Kruesi M, Jovanovic ZR, dos Santos EC, Yoon HC, Steinfeld A. Solar-driven steam-based gasification of sugarcane bagasse in a combined drop-tube and fixed-bed reactor - Thermodynamic, kinetic, and experimental analyses. Biomass and Bioenergy 2013;52:173-83. doi:10.1016/j.biombioe.2013.03.003.

[127] Ravaghi-Ardebili Z, Manenti F, Corbetta M, Pirola C, Ranzi E. Biomass gasification using low-temperature solar-driven steam supply. Renew Energy 2015;74:671-80. doi:10.1016/j.renene.2014.07.021.

[128] Gupta M, Pramanik S, Ravikrishna RV. Development of a syngas-fired catalytic combustion system for hybrid solar-thermal applications. Appl Therm Eng 2016. doi:10.1016/j.applthermaleng.2016.04.150.

[129] Pramanik S, Ravikrishna RV. A novel syngas-fired hybrid heating source for solar-thermal applications: Energy and exergy analysis. Appl Therm Eng 2016. doi:10.1016/j.applthermaleng.2016.04.139. 
[130] Guo P, Saw W, van Eyk P, Ashman P, Nathan G, Stechel E. Fischer-tropsch liquid Fuel Production by Cogasification of Coal and Biomass in a Solar Hybrid Dual Fluidized Bed Gasifier. Energy Procedia 2015;69:1770-9. doi:10.1016/j.egypro.2015.03.147.

[131] Gordillo ED, Belghit A. A bubbling fluidized bed solar reactor model of biomass char high temperature steam-only gasification. Fuel Process Technol 2011;92:314-21. doi:10.1016/j.fuproc.2010.09.021.

[132] Pozzobon V, Salvador S, Bézian JJ. Biomass gasification under high solar heat flux: Experiments on thermally thick samples. Fuel 2016;174:257-66. doi:10.1016/j.fuel.2016.02.003.

[133] Tanaka Y, Mesfun S, Umeki K, Toffolo A, Tamaura Y, Yoshikawa K. Thermodynamic performance of a hybrid power generation system using biomass gasification and concentrated solar thermal processes. Appl Energy 2015;160:664-72. doi:10.1016/j.apenergy.2015.05.084.

[134] Tanaka Y, Umeki K, Tamaura Y, Yoshikawa K. Performance of a Hybrid Power Generation System Using Biomass Gasification and Concentrated Solar Thermal Processes. Energy Procedia 2014;61:2149-53. doi:10.1016/j.egypro.2014.12.097.

[135] Liu Q, Bai Z, Wang X, Lei J, Jin H. Investigation of thermodynamic performances for two solar-biomass hybrid combined cycle power generation systems. Energy Convers Manag 2016;122:252-62. doi:10.1016/j.enconman.2016.05.080.

[136] Zhang X, Li H, Liu L, Zeng R, Zhang G. Analysis of a feasible trigeneration system taking solar energy and biomass as co-feeds. Energy Convers Manag 2016;122:74-84. doi:10.1016/j.enconman.2016.05.063.

[137] Vidal M, Martín M. Optimal coupling of a biomass based polygeneration system with a concentrated solar power facility for the constant production of electricity over a year. Comput Chem Eng 2015;72:273-83. doi:10.1016/j.compchemeng.2013.11.006.

[138] Vidal M, Martín L, Martín M. Optimal Integration of a Concentrated Solar Plant Facility with a Biomass Based Polygeneration System. Comput. Aided Chem. Eng., vol. 33, 2014, p. 1603-8. doi:10.1016/B9780444-63455-9.50102-1.

[139] Bai Z, Liu Q, Li H, Jin H. Performance Analysis of a Polygeneration System for Methanol Production and Power Generation with Solar-biomass Thermal Gasification. Energy Procedia 2014;61:1561-4. doi:10.1016/j.egypro.2014.12.170.

[140] Bai Z, Liu Q, Lei J, Li H, Jin H. A polygeneration system for the methanol production and the power generation with the solar-biomass thermal gasification. Energy Convers Manag 2015;102:190-201. doi:10.1016/j.enconman.2015.02.031.

[141] Tchanche BF, Lambrinos G, Frangoudakis A, Papadakis G. Low-grade heat conversion into power using organic Rankine cycles - A review of various applications. Renew Sustain Energy Rev 2011;15:3963-79. doi:10.1016/j.rser.2011.07.024.

[142] Vélez F, Segovia JJ, Martín MC, Antolín G, Chejne F, Quijano A. A technical, economical and market review of organic Rankine cycles for the conversion of low-grade heat for power generation. Renew Sustain Energy Rev 2012;16:4175-89. doi:10.1016/j.rser.2012.03.022.

[143] Astolfi M, Xodo L, Romano MC, Macchi E. Technical and economical analysis of a solar-geothermal hybrid plant based on an Organic Rankine Cycle. Geothermics 2011;40:58-68. doi:10.1016/j.geothermics.2010.09.009.

[144] Ayub M, Mitsos A, Ghasemi H. Thermo-economic analysis of a hybrid solar-binary geothermal power plant. Energy 2015;87:326-35. doi:10.1016/j.energy.2015.04.106.

[145] Ghasemi H, Sheu E, Tizzanini A, Paci M, Mitsos A. Hybrid solar-geothermal power generation: Optimal retrofitting. Appl Energy 2014;131:158-70. doi:10.1016/j.apenergy.2014.06.010.

[146] Zhou C. Hybridisation of solar and geothermal energy in both subcritical and supercritical Organic Rankine Cycles. Energy Convers Manag 2014;81:72-82. doi:10.1016/j.enconman.2014.02.007.

[147] Lentz Á, Almanza R. Solar-geothermal hybrid system. Appl Therm Eng 2006;26:1537-44. doi:10.1016/j.applthermaleng.2005.12.008.

[148] Zhou C, Doroodchi E, Moghtaderi B. An in-depth assessment of hybrid solar-geothermal power generation. Energy Convers Manag 2013;74:88-101. doi:10.1016/j.enconman.2013.05.014.

[149] Lentz Á, Almanza R. Parabolic troughs to increase the geothermal wells flow enthalpy. Sol Energy 2006;80:1290-5. doi:10.1016/j.solener.2006.04.010.

[150] Al-Ali M, Dincer I. Energetic and exergetic studies of a multigenerational solar-geothermal system. Appl Therm Eng 2014;71:16-23. doi:10.1016/j.applthermaleng.2014.06.033. 
[151] Calise F, d'Accadia MD, Macaluso A, Piacentino A, Vanoli L. Exergetic and exergoeconomic analysis of a novel hybrid solar-geothermal polygeneration system producing energy and water. Energy Convers Manag 2016;115:200-20. doi:10.1016/j.enconman.2016.02.029.

[152] Ezzat MF, Dincer I. Energy and exergy analyses of a new geothermal-solar energy based system. Sol Energy 2016;134:95-106. doi:10.1016/j.solener.2016.04.029.

[153] Ghosh S, Dincer I. Development and analysis of a new integrated solar-wind-geothermal energy system. Sol Energy 2014;107:728-45. doi:10.1016/j.solener.2014.06.006.

[154] Buonomano A, Calise F, Palombo A, Vicidomini M. Energy and economic analysis of geothermal-solar trigeneration systems: A case study for a hotel building in Ischia. Appl Energy 2015;138:224-41. doi:10.1016/j.apenergy.2014.10.076.

[155] Eslami-nejad P, Bernier M. Coupling of geothermal heat pumps with thermal solar collectors using double U-tube boreholes with two independent circuits. Appl Therm Eng 2011;31:3066-77. doi:10.1016/j.applthermaleng.2011.05.040.

[156] Bicer Y, Dincer I. Analysis and performance evaluation of a renewable energy based multigeneration system. Energy 2016;94:623-32. doi:10.1016/j.energy.2015.10.142.

[157] Ruzzenenti F, Bravi M, Tempesti D, Salvatici E, Manfrida G, Basosi R. Evaluation of the environmental sustainability of a micro CHP system fueled by low-temperature geothermal and solar energy. Energy Convers Manag 2014;78:611-6. doi:10.1016/j.enconman.2013.11.025.

[158] Tempesti D, Fiaschi D. Thermo-economic assessment of a micro CHP system fuelled by geothermal and solar energy. Energy 2013;58:45-51. doi:10.1016/j.energy.2013.01.058.

[159] Tempesti D, Manfrida G, Fiaschi D. Thermodynamic analysis of two micro CHP systems operating with geothermal and solar energy. Appl Energy 2012;97:609-17. doi:10.1016/j.apenergy.2012.02.012.

[160] Suleman F, Dincer I, Agelin-Chaab M. Development of an integrated renewable energy system for multigeneration. Energy 2014;78:196-204. doi:10.1016/j.energy.2014.09.082.

[161] Radziemska E. The effect of temperature on the power drop in crystalline silicon solar cells. Renew Energy 2003;28:1-12. doi:10.1016/S0960-1481(02)00015-0.

[162] Royne A, Dey CJ, Mills DR. Cooling of photovoltaic cells under concentrated illumination: a critical review. Sol Energy Mater Sol Cells 2005;86:451-83. doi:10.1016/j.solmat.2004.09.003.

[163] Makki A, Omer S, Sabir H. Advancements in hybrid photovoltaic systems for enhanced solar cells performance. Renew Sustain Energy Rev 2015;41:658-84. doi:10.1016/j.rser.2014.08.069.

[164] Michael JJ, S I, Goic R. Flat plate solar photovoltaic-thermal (PV/T) systems: A reference guide. Renew Sustain Energy Rev 2015;51:62-88. doi:10.1016/j.rser.2015.06.022.

[165] Li S, Joe J, Hu J, Karava P. System identification and model-predictive control of office buildings with integrated photovoltaic-thermal collectors, radiant floor heating and active thermal storage. Sol Energy 2015;113:139-57. doi:10.1016/j.solener.2014.11.024.

[166] Liang R, Zhang J, Zhou C. Dynamic Simulation of a Novel Solar Heating System Based on Hybrid Photovoltaic/Thermal Collectors (PVT). Procedia Eng 2015;121:675-83. doi:10.1016/j.proeng.2015.09.001.

[167] Kazanci OB, Skrupskelis M, Sevela P, Pavlov GK, Olesen BW. Sustainable heating, cooling and ventilation of a plus-energy house via photovoltaic/thermal panels. Energy Build 2014;83:122-9. doi:10.1016/j.enbuild.2013.12.064.

[168] Hailu G, Dash P, Fung AS. Performance Evaluation of an Air Source Heat Pump Coupled with a BuildingIntegrated Photovoltaic/Thermal (BIPV/T) System under Cold Climatic Conditions. Energy Procedia 2015;78:1913-8. doi:10.1016/j.egypro.2015.11.370.

[169] Qu M, Chen J, Nie L, Li F, Yu Q, Wang T. Experimental study on the operating characteristics of a novel photovoltaic/thermal integrated dual-source heat pump water heating system. Appl Therm Eng 2016;94:819-26. doi:10.1016/j.applthermaleng.2015.10.126.

[170] Shan F, Cao L, Fang G. Dynamic performances modeling of a photovoltaic-thermal collector with water heating in buildings. Energy Build 2013;66:485-94. doi:10.1016/j.enbuild.2013.07.067.

[171] Chan CW, Siqueiros E, Ling-Chin J, Royapoor M, Roskilly AP. Heat utilisation technologies: A critical review of heat pipes. Renew Sustain Energy Rev 2015;50:615-27. doi:10.1016/j.rser.2015.05.028.

[172] Jouhara H, Szulgowska-Zgrzywa M, Sayegh MA, Milko J, Danielewicz J, Nannou TK, et al. The performance of a heat pipe based solar PV/T roof collector and its potential contribution in district heating applications. Energy 2016. doi:10.1016/j.energy.2016.04.070. 
[173] Hou L, Quan Z, Zhao Y, Wang L, Wang G. An experimental and simulative study on a novel photovoltaicthermal collector with micro heat pipe array (MHPA-PV/T). Energy Build 2016;124:60-9. doi:10.1016/j.enbuild.2016.03.056.

[174] Kapsalis V, Karamanis D. Solar thermal energy storage and heat pumps with phase change materials. Appl Therm Eng 2016;99:1212-24. doi:10.1016/j.applthermaleng.2016.01.071.

[175] Browne MC, Norton B, McCormack SJ. Heat retention of a photovoltaic/thermal collector with PCM. Sol Energy 2016;133:533-48. doi:10.1016/j.solener.2016.04.024.

[176] Lin W, Ma Z. Using Taguchi-Fibonacci search method to optimize phase change materials enhanced buildings with integrated solar photovoltaic thermal collectors. Energy 2016;106:23-37. doi:10.1016/j.energy.2016.03.013.

[177] Navarro L, de Gracia A, Colclough S, Browne M, McCormack SJ, Griffiths P, et al. Thermal energy storage in building integrated thermal systems: A review. Part 1. active storage systems. Renew Energy 2015;88:526-47. doi:10.1016/j.renene.2015.11.040.

[178] Verma V, Kane A, Singh B. Complementary performance enhancement of PV energy system through thermoelectric generation. Renew Sustain Energy Rev 2016;58:1017-26. doi:10.1016/j.rser.2015.12.212.

[179] Da Y, Xuan Y, Li Q. From light trapping to solar energy utilization: A novel photovoltaic-thermoelectric hybrid system to fully utilize solar spectrum. Energy 2016;95:200-10. doi:10.1016/j.energy.2015.12.024.

[180] Vick BD, Moss TA. Adding concentrated solar power plants to wind farms to achieve a good utility electrical load match. Sol Energy 2013;92:298-312. doi:10.1016/j.solener.2013.03.007.

[181] Santos-Alamillos FJ, Pozo-Vázquez D, Ruiz-Arias JA, Von Bremen L, Tovar-Pescador J. Combining wind farms with concentrating solar plants to provide stable renewable power. Renew Energy 2015;76:539-50. doi:10.1016/j.renene.2014.11.055.

[182] Reichling J, Kulacki F. Utility scale hybrid wind-solar thermal electrical generation: A case study for Minnesota. Energy 2008;33:626-38. doi:10.1016/j.energy.2007.11.001.

[183] Petrakopoulou F, Robinson A, Loizidou M. Simulation and evaluation of a hybrid concentrating-solar and wind power plant for energy autonomy on islands. Renew Energy 2016;96:863-71. doi:10.1016/j.renene.2016.05.030.

[184] Okazaki T, Shirai Y, Nakamura T. Concept study of wind power utilizing direct thermal energy conversion and thermal energy storage. Renew Energy 2015;83:332-8. doi:10.1016/j.renene.2015.04.027. 